\begin{tabular}{|c|c|c|c|c|c|c|c|c|}
\hline \multicolumn{3}{|c|}{$\begin{array}{l}\text { 2. To: (Receiving Organization) } \\
\text { Distribution }\end{array}$} & \multicolumn{2}{|c|}{$\begin{array}{l}\text { 3. From: (Originating Organization) } \\
\text { Nuclear Safety }\end{array}$} & \multicolumn{4}{|c|}{$\begin{array}{l}\text { 4. Related EDT No.: } \\
\qquad \text { N/A }\end{array}$} \\
\hline \multicolumn{3}{|c|}{$\begin{array}{l}\text { 5. Proj./Prog./Dept/Div.: } \\
\text { Spent Nuclear Fuel Project }\end{array}$} & \multicolumn{2}{|c|}{$\begin{array}{l}\text { 6. Design Authority/Design Agent/Cog. Engr.: } \\
\text { R. P. DiPiazza }\end{array}$} & \multicolumn{4}{|c|}{$\begin{array}{r}\text { 7. Purchase Order No.: } \\
\text { N/A }\end{array}$} \\
\hline \multicolumn{5}{|c|}{ 8. Originator Remarks: } & \multicolumn{4}{|c|}{$\begin{array}{r}\text { 9. Equip./Component No.: } \\
\text { N/A }\end{array}$} \\
\hline \multicolumn{5}{|c|}{ For approval and release. } & \multicolumn{4}{|c|}{$\begin{array}{r}\text { 10. Systom/Bldg.Fracility: } \\
\text { W-379 }\end{array}$} \\
\hline \multirow{3}{*}{\multicolumn{2}{|c|}{ 11. Receiver Remarks: }} & \multirow{3}{*}{\multicolumn{3}{|c|}{ 11A Design Baseline Document? [] Yes [x] No }} & \multicolumn{4}{|c|}{$\begin{array}{r}\text { 12. Major Assm. Dwg. No.: } \\
\text { N/A }\end{array}$} \\
\hline & & & & & \multicolumn{4}{|c|}{$\begin{array}{l}\text { 13. Permit/Permit Application No.: } \\
\text { N/A }\end{array}$} \\
\hline & & & & & \multicolumn{4}{|c|}{$\begin{array}{l}\text { 14. Required Response Date: } \\
\text { N/A }\end{array}$} \\
\hline 15. & & DAT & TRANSMI & & (F) & (G) & (H) & (I) \\
\hline $\begin{array}{l}(A) \\
\text { Item } \\
\text { No. }\end{array}$ & (B) Documentidnwing No. & $\begin{array}{l}\text { (C) } \\
\text { shoet } \\
\text { No. }\end{array}$ & $\begin{array}{l}\text { (D) } \\
\text { Rev. } \\
\text { No. }\end{array}$ & (E) Tith or Description of Dest Therenittod & $\begin{array}{l}\text { Appronal } \\
\text { Docienator }\end{array}$ & 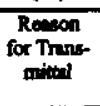 & $\begin{array}{l}\text { Oripi- } \\
\text { netor } \\
\text { Dippo- } \\
\text { sition }\end{array}$ & $\begin{array}{c}\text { Rexiver } \\
\text { Dispocition }\end{array}$ \\
\hline 1 & SNF-4831 & N/A & 0 & $\begin{array}{l}\text { Human Factors Engineering } \\
\text { and Ergonomics Analysis for } \\
\text { the Canister Storage Building: } \\
\text { Results and Findings }\end{array}$ & $\bar{S}$ & 1,2 & 1 & 1 \\
\hline & & & & & & & . & \\
\hline & & & & & & & & \\
\hline & & & & & & & & \\
\hline & & & & & & & & \\
\hline & & & & & & & & \\
\hline
\end{tabular}

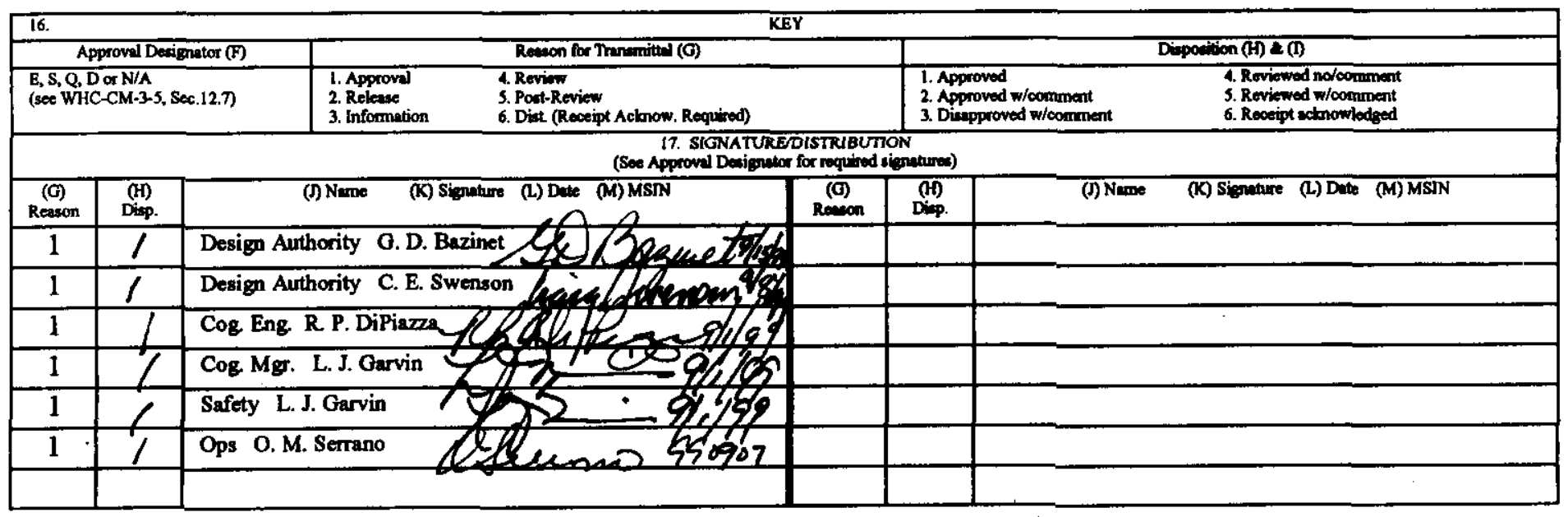

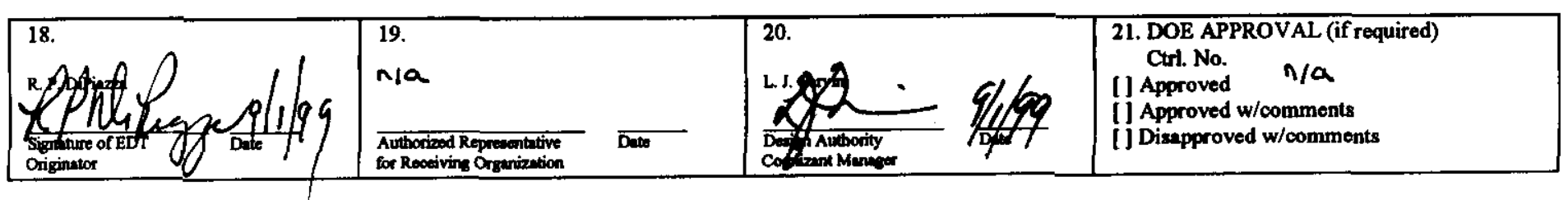

BD-7400-172-2 (0\$/96) GEF097 


\section{Human Factors Engineering and Ergonomics Analysis for the Canister Storage Building: Results and Findings}

R. Imker

Fluor Daniel Hanford, Inc., Richland, WA 99352

U.S. Department of Energy Contract DE-AC06-96RL13200

EDT: 626889

UC: 920

Org Code: 2F200

Charge Code: 105625/BB20

B\&R Code: EW31354040

Total Pages: 123

Key Words: Human Factors, Ergonomics, Canister Storage Building, CSB

Abstract: The purpose for this supplemental report is to follow-up and update the information in SNF3907, Human Factors Engineering (HFE) Analysis: Results and Findings. This supplemental report responds to applicable U.S. Department of Energy Safety Analysis Report review team comments and questions. This Human Factors Engineering and Ergonomics (HFE/Erg) analysis was conducted from April 1999 to July 1999; SNF-3907 was based on analyses accomplished in October 1998.

The HFE/Erg findings presented in this report and SNF-3907, along with the results of HNF3553, Spent Nuclear Fuel Project, Final Safety Analysis Report, Annex A, "Canister Storage Building Final Safety Analysis Report," Chapter A3.0, "Hazards and Accidents Analyses," provide the technical basis for preparing or updating HNF-3553, Annex A, Chapter A13.0, "Human Factors Engineering." The findings presented in this report allow the HNF-3553 Chapter 13.0, "Human Factors," to respond fully to the HFE requirements established in DOE Order 5480.23, Nuclear Safety Analysis Reports.

TRADEMARK DISCLAIMER. Reference herein to any specific commercial product, process, or service by trade name, trademark, manufacturer, or otherwise, does not necessarily constitute or imply its endorsement, recommendation, or favoring by the United States Government or any agency thereof or its contractora or subcontractors.

Printed in the United States of America. To obtain copies of this document, contact: Document Control Services, P.0. Box 950, Mailstop H6-08, Richland WA 99352, Phone (509) 372-2420; Fax (509) 376-4989.
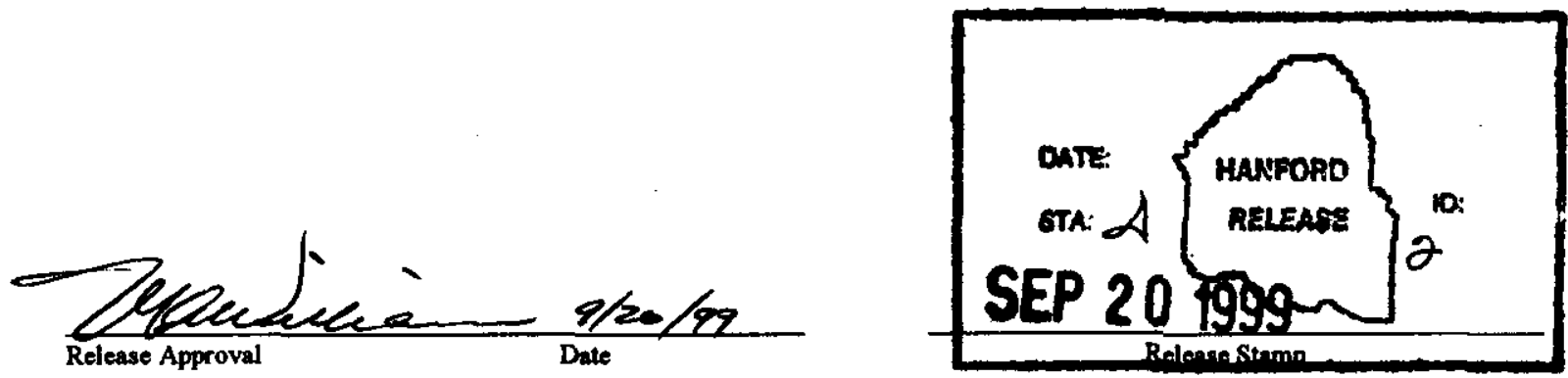

\section{Approved for Public Release}




\section{HUMAN FACTORS ENGINEERING AND ERGONOMICS ANALYSIS FOR THE CANISTER STORAGE BUILDING: RESULTS AND FINDINGS \\ (Supplemental Report)}

SNF-4831

Revision 0 
SNF-4831 REV 0

This page intentionally left blank. 


\section{CONTENTS}

1.0 INTRODUCTION AND SUMMARY

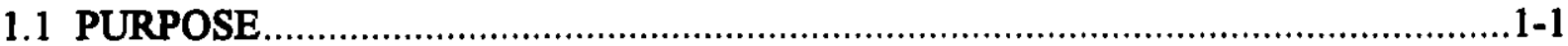

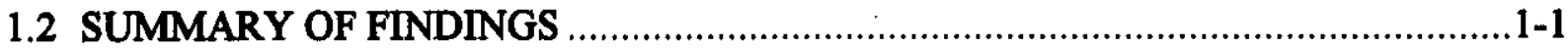

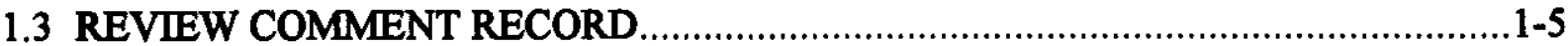

1.4 PROCEDURE FOR THIS ABBREVIATED REPORT …......................................

1.5 HUMAN FACTORS ENGINEERING AND ERGONOMICS (HFE/ERG) GRADED APPROACH

2.0 CANISTER STORAGE BUILDING FACILITY DESCRIPTION AND OPERATING

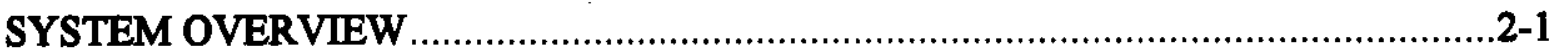

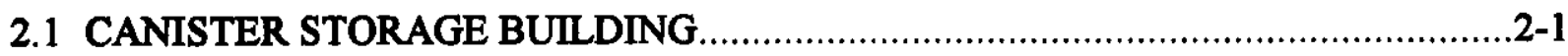

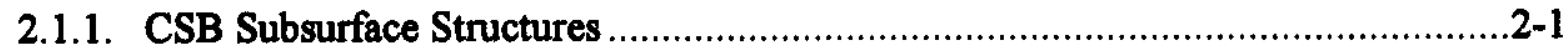

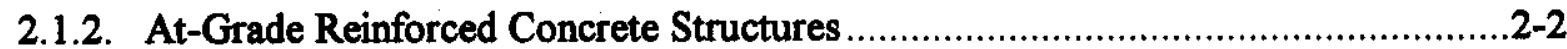

2.1.3. Canister Storage Building Steel Structures .........................................................

2.1.4. Canister Storage Building Above-Grade Structures ............................................2-4

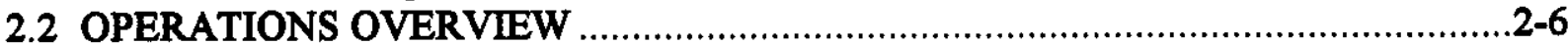

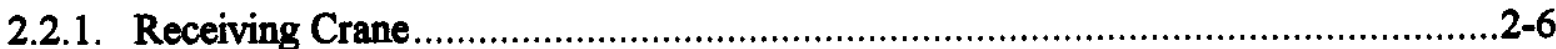

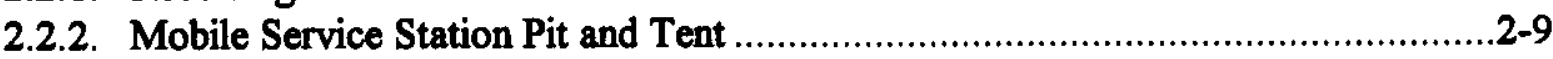

2.2.3. Cask Servicing (Multi-Canister Overpack Service Station Pit) and Operations.....2-10

2.2.4. Multi-Canister Overpack Handling Machine And Operations..............................2-11

2.2.5. Multi-Canister Overpack Sampling/Weld Operations ............................................2-15

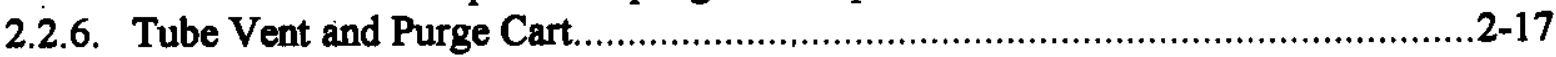

2.2.7. Heating, Ventilation, and Air Conditioning System.........................................2-19

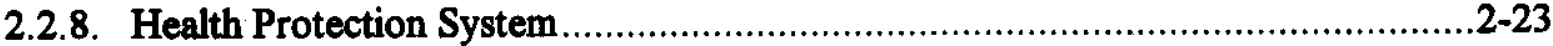

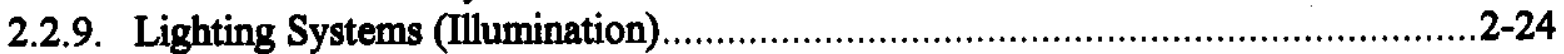

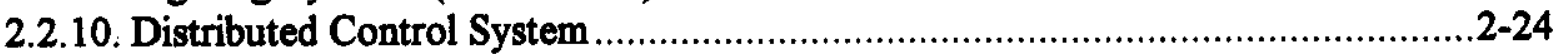

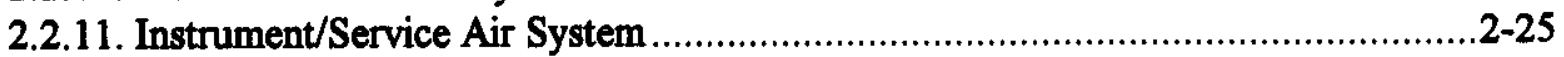

2.2.12. Gaseous Effluent Monitoring System .......................................................2-

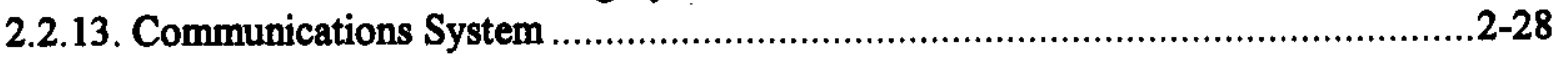

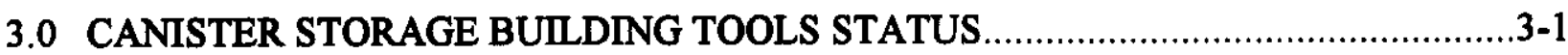

4.0 CANISTER STORAGE BUILDING HAZARD ANALYSIS ….................................

5.0 INFORMATION PROVIDED IN FLUOR DANIEL HANFORD, INC. LETTERS ….....5-1

6.0 HUMAN FACTORS ENGINEERING/ERGONOMIC EVALUATION ..........................6-1

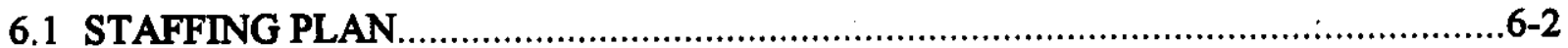

6.1.1. Staffing Key Operational Assumptions for the Canister Storage Building ...............6-3

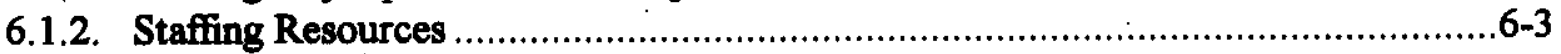

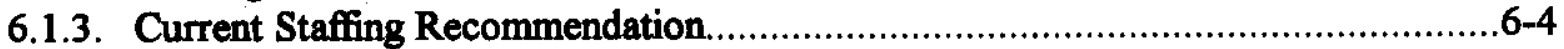

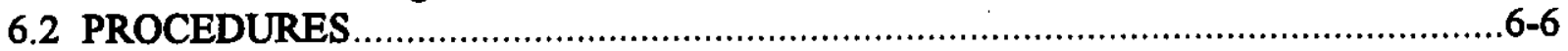


7.0 HUMAN ENGINEERING DEFICIENCY TRACKING

7.1 TEST AND VALIDATION

7.2 DISCUSSION OF HUMAN FACTORS ENGINEERING/ERGONOMIC DEFICIENCIES/DEVIATIONS FROM CANISTER STORAGE BUILDING HUMAN FACTORS ENGINEERING REPORT (SNF-3907)

8.0 LIMITATIONS OF THIS REPORT

9.0 REFERENCES 9-1

APPENDIX A OPERATIONAL SEQUENCE BLOCK FLOW DIAGRAM OVERVIEW (H-2123400, SHEETS 1-7) 


\section{LIST OF FIGURES}

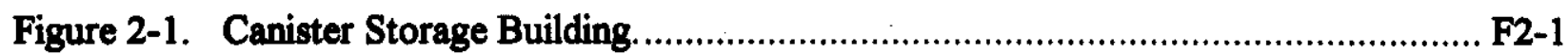

Figure 2-2. Canister Storage Building Operating Deck Plan View................................... F2-2

Figure 2-3. Cask Transportation System Arrangement.................................................. F2-3

Figure 2-4. Cask Transportation Safety System Arrangement. ........................................ F2-4

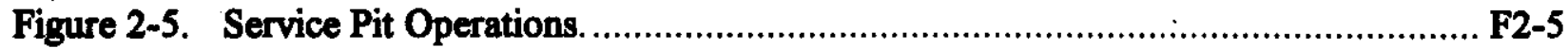

Figure 2-6. Multi-Canister Overpack Handling Machine. ............................................. F2-6

Figure 2-7. Multi-Canister Overpack Handling Machine Cask Turret Assembly .................. F2-7

Figure 2-8. Multi-Canister Overpack Hoist Assembly. .................................................. F2-8

Figure 2-9. Tube Plug Grapple. ............................................................................. F2

Figure 2-10. Multi-Canister Overpack Handling Machine Cask Shielding ...........................F2-10

Figure 2-11. Sampling/Weld Station Gantry Crane. ....................................................F2-11

Figure 2-12. Multi-Canister Overpack in Sampling/Weld Pit..........................................F2-12

Figure 2-13: Tube Vent and Purge Cart. (sheet 1 of 2) .....................................................13

Figure 2-13. Tube Vent and Purge Cart. (sheet 2 of 2) ..................................................F2-14

Figure 2-14. Distributed Control System. ………......................................................22-15

\section{LIST OF TABLES}

Table 1-1. Summary of HFE Compliances for Selected CSB Systems or Components (4 sheets) ....................................................................................

Table 1-2. Summary of Review Comment Record. (3 sheets) ...............................................1-6

Table 1-3. Summary Analysis of HFE/Erg Graded Approach. (4 sheets) ................................1-11

Table 3-1. Canister Storage Building Tool Status. (5 sheets) ..............................................3-1

Table 4-1. Canister Storage Building Hazard Analysis Table (Human Error). (14 sheets).........4-2 


\section{LIST OF TERMS}

$\begin{array}{ll}\text { ALARA } & \text { as low as reasonably achievable } \\ \text { ANSI } & \text { American National Standards Institute } \\ \text { ASME } & \text { American Society of Mechanical Engineers } \\ \text { CCTV } & \text { closed circuit television } \\ \text { CFR } & \text { Code of Federal Regulations } \\ \text { CSB } & \text { Canister Storage Building } \\ \text { CVDF } & \text { Cold Vacuum Drying Facility } \\ \text { DCS } & \text { distributed control system } \\ \text { DOE } & \text { U.S. Department of Energy } \\ \text { FFTF } & \text { Fast Flux Test Facility } \\ \text { FSAR } & \text { final safety analysis report } \\ \text { GEMS } & \text { gaseous effluent monitoring system } \\ \text { HED } & \text { human engineering deficiency } \\ \text { HEPA } & \text { high efficiency particulate air filter } \\ \text { HFE } & \text { human factors engineering } \\ \text { HMI } & \text { human-machine interface } \\ \text { HPT } & \text { health physics technician } \\ \text { HVAC } & \text { heating, ventilation, and air conditioning } \\ \text { ISA } & \text { instrument/service air system } \\ \text { MCO } & \text { multi-canister overpack } \\ \text { MHM } & \text { multi-canister overpack handling machine } \\ \text { MTU } & \text { metric ton uranium } \\ \text { NEMA } & \text { National Electrical Manufacturer's Association } \\ \text { NRC } & \text { U.S. Nuclear Regulatory Commission } \\ \text { OHVAC } & \text { operating area HVAC (subsystem) } \\ \text { PSV } & \text { pressure safety valve } \\ \text { RCR } & \text { review comment record } \\ \text { SAR } & \text { safety analysis report } \\ \text { SDD } & \text { system design description } \\ \text { SHVAC } & \text { support area HVAC (subsystem) } \\ \text { SNF } & \text { spent nuclear fuel } \\ \text { SSC } & \text { structures, systems, and components } \\ \text { TSR } & \text { technical safety requirement } \\ \text { UPS } & \text { uninterruptable power supply } \\ & \end{array}$




\subsection{INTRODUCTION AND SUMMARY}

\subsection{PURPOSE}

The purpose for this supplemental report is to follow-up and update the information found in SNF-3907, Human Factors Engineering (HFE) Analysis: Results and Findings. This supplemental report is abbreviated in order to respond to applicable U.S. Department of Energy (DOE) Safety Analysis Report (SAR) review team comments and questions. This Human Factors Engineering and Ergonomics (HFE/Erg) analysis was conducted from April 1999 to July 1999; SNF-3907 was based on analyses accomplished in October 1998.

This supplemental report makes no attempt to interpret or evaluate the safety significance of the HFE/Erg analyses findings. The HFE/Erg findings presented in this report and in SNF3907, along with the results of HNF-3553, Spent Nuclear Fuel Project, Final Safety Analysis Report, Annex A, "Canister Storage Building Final Safety Analysis Report," Chapter A3.0, "Hazards and Accidents Analyses," provide the technical basis for preparing or updating HNF3553, Annex A, Chapter A13.0, "Human Factors Engineering." The findings presented in this report allow the HNF-3553 Chapter 13.0, "Human Factors," to respond fully to the HFE requirements established in DOE Order 5480.23, Nuclear Safety Analysis Reports.

\subsection{SUMMARY OF FINDINGS}

The Canister Storage Building (CSB) system reveals much thought and ongoing consideration for human-machine interfacing. Almost all of the facility structure is in place. HNF-3553, Annex A, Chapter A13.0, "Human Factors," is appropriately updated after changes affecting HFE/Erg are identified and reviewed. A few ergonomics concerns have been identified and brought out in Section 6.0, HFE/Erg Evaluation. The need for continued inclusion of HFE/Erg is apparent, especially to follow up on Human Engineering Deficiencies (HEDs) identified in other HFE reports but not yet resolved at this time; for example, how to deal with the human interaction during multi-canister overpack (MCO) cask servicing. For these items, a deficiency tracking system is advised and briefly discussed in this report; this includes Table 1-1, Summary of HFE Compliances for Selected CSB Systems or Components, which may be used for tracking purposes. A brief tour of the building was conducted in order to have some familiarization with the building layout and equipment already installed. This brief review looked at almost every system currently considered for CSB, and found that in the course of design work, consideration is provided for integrating the operator into the facility design to ensure safe and efficient operation of the CSB. HFE/Erg should be evaluated in detail during the test and evaluation phase of the project to check for HEDs not previously identified. A checklist approach is highly recommended for this phase of the project, and should be accomplished in partnership with training in going over each and every task to ensure the task is safely and efficiently accomplished by the operator. 
A more detailed discussion of the HFE graded pproach is presented in this report. This shows why a number of CSB subsystems may not have had as intense an HFE analysis as originally anticipated. Many subsystems, once installed, will be operating in the background with very little human interaction, except for applicable routine maintenance (inspections, calibrations, or possibly a part changeout). A check for accessibility (physical access) with regard to maintenance and work with system specific tools is important. Accessibility was considered for the systems associated with CSB and found acceptable, however, a further check should again be accomplished during the pre-operation test and evaluation when the entire system is running in an "operational" mode.

The CSB current staffing plan was reviewed. Some environment data was provided in HNF-3553, Annex A, Chapter A2.0 on the facility design. Additional information will be needed, and this can be reviewed during periodic HFE reviews of design progress, with appropriate updating of the FSAR, and when the design nears completion. Therefore, this brief review of the current CSB system, along with previous HFE reports, will assist in updating the CSB FSAR. Overall, the CSB appears well designed with proper insertion of the operator into the system and is well on track to meeting applicable requirements for HFE/Erg. Only a few systems now need $\mathrm{HFE} / \mathrm{Erg}$ verification, as they were still in design stages and the system hardware was not available to examine, for example, tube vent and purge cart. In this case, an examination of the vendor specification revealed the appropriate inclusion of HFE/Erg considerations, which can be verified at an engineering acceptance test. The frog tool will be reviewed when ready, and the weld station is undergoing redesign. There is the possibility of the Mobile Service Station tent being eliminated altogether, so this should be followed for design change(s).

A summary of the CSB HFE analysis is provided in Table 1-1, Summary of HFE Compliances for Selected CSB Systems or Components. This included the checklist evaluation for each CSB subsystem or component, as appropriate. Included are identified deficiencies that have been brought to the attention of engineering and where appropriate, a suggested solution has been provided. The identified deficiencies represent "no" answers to the checklist criteria. If no identified deficiencies are cited, then this indicates either the system met the HFE criteria, or the checklist criteria was not applicable. The deficiency being listed here, serves to track the deficiency to its resolution through engineering (also, see Section 7.0, this report).

Table 1-1. Summary of HFE Compliances for Selected CSB Systems or Components (4 sheets)

\begin{tabular}{|c|c|c|c|c|}
\hline $\begin{array}{c}\text { Solocted } \\
\text { Systems or Components } \\
\text { Evaluated }\end{array}$ & $\begin{array}{l}\text { Selected and Applied } \\
\text { Checklists }\end{array}$ & $\begin{array}{l}\text { Identified HFE/Erg } \\
\text { Deficiencies }\end{array}$ & $\begin{array}{l}\text { Suggested HFE/Erg } \\
\text { Resolutions }\end{array}$ & $\begin{array}{l}\text { Resolution prior to } \\
\text { Pro-operational } \\
\text { Test \& Evaluation }\end{array}$ \\
\hline Support Area Building & $\begin{array}{l}\text { Checklist 1: Operational Aids } \\
\text { Checklist 12: Labeling } \\
\text { Checklist 11: User-Computer } \\
\text { Interface } \\
\text { Checklist 14: Environment } \\
\text { Checklist 16: Hazards \& Safety } \\
\text { Checklist 17: Physical Access }\end{array}$ & $\begin{array}{l}\text { None identified } \\
\text { (observation of all pertinent } \\
\text { rooms and service } \\
\text { equipment in and around } \\
\text { support area building) }\end{array}$ & - & \\
\hline Receiving Crane & $\begin{array}{l}\text { Checklist 12: Labeling } \\
\text { Checklist 14: Environment } \\
\text { Checklist 15: Operations \& } \\
\text { Maintenance: Vehicles }\end{array}$ & $\begin{array}{l}\text { 1. Visibility from crane } \\
\text { operations panel to } \\
\text { Cask/MCO. } \\
\text { 2. Potential safety concern }\end{array}$ & $\begin{array}{l}\text { 1. Use spotter to help } \\
\text { crane operator, or use } \\
\text { radio control. } \\
\text { 2. Use padding in }\end{array}$ & \\
\hline
\end{tabular}


Table 1-1. Summary of HFE Compliances for Selected CSB Systems or Components (4 sheets)

\begin{tabular}{|c|c|c|c|c|}
\hline $\begin{array}{c}\text { Selected } \\
\text { Syutems or Components } \\
\text { Evaluated }\end{array}$ & $\begin{array}{l}\text { Soloctod and Appliod } \\
\text { Chectlist }\end{array}$ & $\begin{array}{l}\text { Identified HFE/Erg } \\
\text { Doficiencies }\end{array}$ & $\begin{array}{l}\text { Suggestod HFE/Erg } \\
\text { Resolutions }\end{array}$ & $\begin{array}{l}\text { Resolution prior to } \\
\text { Pro-operational } \\
\text { Teet \& Evaluation }\end{array}$ \\
\hline & 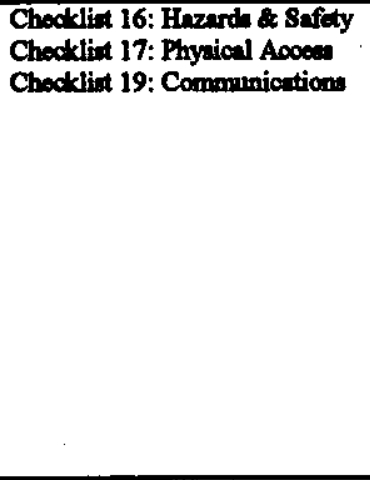 & $\begin{array}{l}\text { of thep corner on right side } \\
\text { of the operator platform } \\
\text { work area. } \\
\text { 3. Main and auxiliary hoist } \\
\text { controls appear inconsistent } \\
\text { with direction of operation } \\
\text { 4. Crane joystick controbs } \\
\text { can bo inadvertently } \\
\text { activated by an operator } \\
\text { loaning over controls to } \\
\text { viow through shielded } \\
\text { window. }\end{array}$ & $\begin{array}{l}\text { area of potential } \\
\text { head/orane booth } \\
\text { contact. } \\
\text { 3. Recheck controls } \\
\text { are consistent with } \\
\text { Hanford crane } \\
\text { prooocture. } \\
\text { 4. Use of a barrier will } \\
\text { rectuce likelihood of } \\
\text { inadvertent sotivation } \\
\text { (also, crano may be } \\
\text { primurily operated } \\
\text { from a radio control } \\
\text { box). }\end{array}$ & \\
\hline $\begin{array}{l}\text { Recoiving Crane Lifting } \\
\text { Yoke }\end{array}$ & $\begin{array}{l}\text { Cheoklint 15: Operations \& } \\
\text { Maintenanoe: Vehicles } \\
\text { Checklint 16: Hazand \& Safety }\end{array}$ & Nono identified & & \\
\hline Rail Frogas & Checktiat 16: Finzarda \& Safoty & $\begin{array}{l}\text { Lifting tool(s) required to } \\
\text { lift } 700 \text { pound weight (in } \\
\text { docign), mast be mobile. }\end{array}$ & $\begin{array}{l}\text { 1. Automate; or } \\
\text { olectric mobilo cranes; } \\
\text { or manual mobilo } \\
\text { cranes }\end{array}$ & \\
\hline MCO-Cadk & Chocklint 16: Hazarda \& Safdy. & $\begin{array}{l}\text { Nono identified (also } \\
\text { tudied under CVDF) }\end{array}$ & & \\
\hline $\begin{array}{l}\text { Cack Trandfar Safdy } \\
\text { Syutem (truck/trailec) }\end{array}$ & Checkfiat 16: Frazarda \& Safoty & $\begin{array}{l}\text { None identified (also } \\
\text { studied under CVDF) }\end{array}$ & & \\
\hline $\begin{array}{l}\text { Mobilo Servioe Station } \\
\text { Teut/ Gantry Hoist }\end{array}$ & $\begin{array}{l}\text { Chocklint 15: Operations \& } \\
\text { Maintenanoe: Vehioles } \\
\text { Chocklint 16: Hazarda \& Safety }\end{array}$ & $\begin{array}{l}\text { 1. Tent woight exceative } \\
\text { (tent may be eliminnted by } \\
\text { deatign). } \\
\text { 2. Mobilo service station } \\
\text { hatch asembly undergoing } \\
\text { redeaign . }\end{array}$ & $\begin{array}{l}\text { 1. Uso larger whools } \\
\text { and additionsl } \\
\text { operators to push; use } \\
\text { a tractor or tug to } \\
\text { move tent. } \\
\text { 2. Rechock rodesign } \\
\text { for HFE. }\end{array}$ & \\
\hline $\begin{array}{l}\text { MCO Flex Comector, } \\
\text { HEPA Filter, and Piping } \\
\text { between Filter and Cank }\end{array}$ & Checklist 16: Hazands \& Safoty & $\begin{array}{l}\text { 1. chock for easy fitting } \\
\text { connectors. } \\
\text { 2. positive connection } \\
\text { indication }\end{array}$ & $\begin{array}{l}\text { 1. if possible Snsp- } \\
\text { On, snap-off } \\
\text { connectors: depends } \\
\text { cn enginoering } \\
\text { requirements. } \\
\text { 2. Connectors should } \\
\text { be positive locking so } \\
\text { operutor know } \\
\text { connectors are } \\
\text { properly seated. }\end{array}$ & \\
\hline $\begin{array}{l}\text { MCO Servioing Instrumests } \\
\text { (Indrumeat Air Syytemy) }\end{array}$ & Checklist 16: Hazards \& Safidy & None identified & & \\
\hline MCO Sampling Equipment & Checklin 16: Hazards \& Safdy & None identified & & \\
\hline $\begin{array}{l}\text { MCO Tube Veat and Purge } \\
\text { Cart }\end{array}$ & 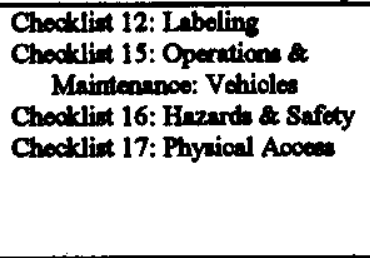 & $\begin{array}{l}\text { None identified at this timo. } \\
\text { 1. Based on drawing and } \\
\text { equipment apocification } \\
\text { (which includes HFE/Eng } \\
\text { consideration). }\end{array}$ & $\begin{array}{l}\text { 1. Check for HFE } \\
\text { application during } \\
\text { engineering } \\
\text { acceptanoe teoting. } \\
\text { (Specification for } \\
\text { HFE was oxcellent) }\end{array}$ & \\
\hline MHM CCTV Syatem & $\begin{array}{l}\text { Chooklint 6: Dioplays } \\
\text { Cheokliat 2: Control/Diaplay } \\
\text { Integration } \\
\text { Checklit 3: Prinoiples of } \\
\text { Visual Digplays } \\
\text { Cheoklist: } 9 \text { Hand Operated } \\
\text { Controls } \\
\text { Checklint 13: Remote Handling }\end{array}$ & Nono identified at this time. & & \\
\hline
\end{tabular}


Table 1-1. Summary of HFE Compliances for Selected CSB Systems or Components (4 sheets)

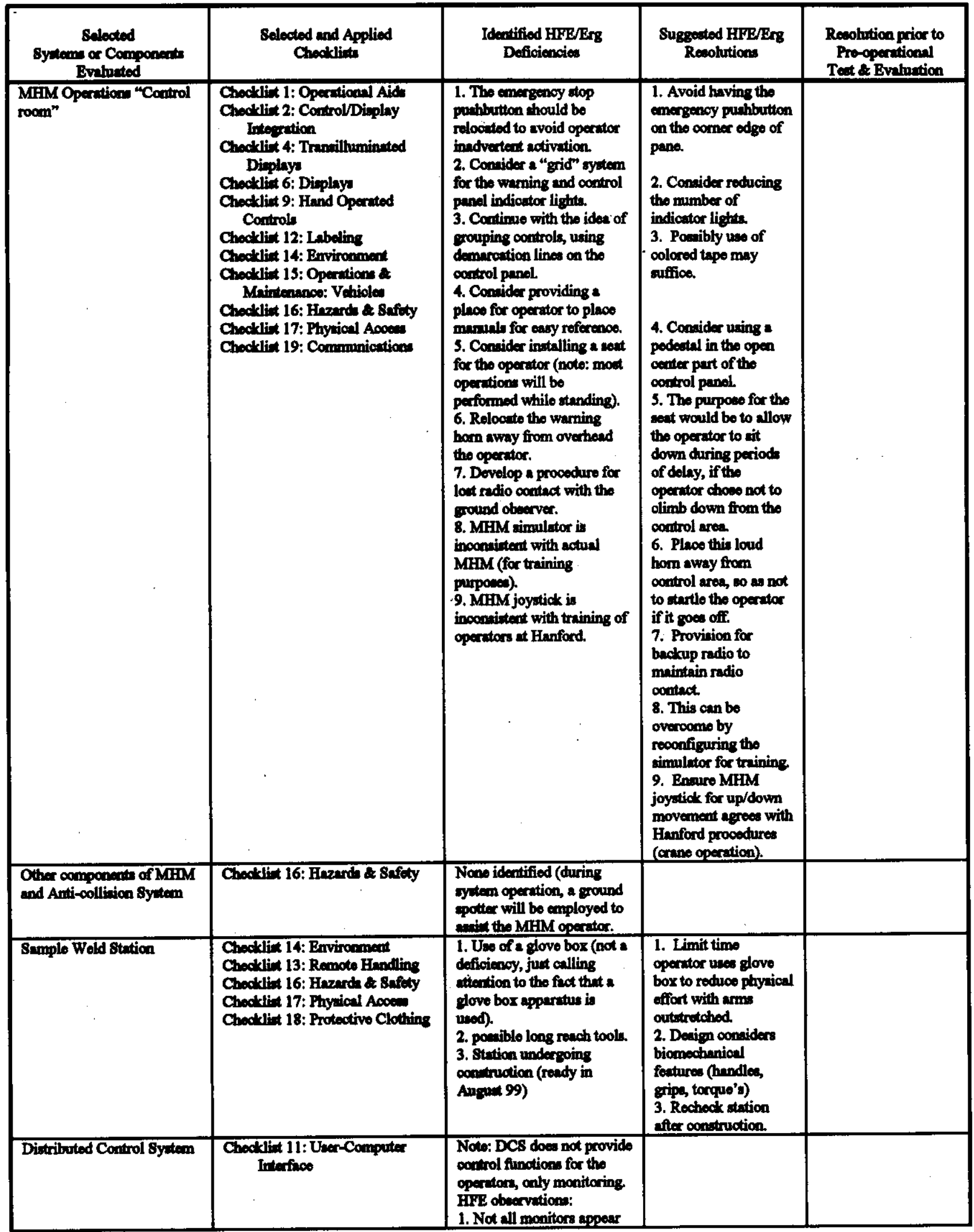


Table 1-1. Summary of HFE Compliances for Selected CSB Systems or Components (4 sheets)

\begin{tabular}{|c|c|c|c|c|}
\hline $\begin{array}{c}\text { Selocted } \\
\text { Syutemin ar Components } \\
\text { Evaluuted }\end{array}$ & $\begin{array}{l}\text { Solocted and Applied } \\
\text { Chocklints }\end{array}$ & $\begin{array}{l}\text { Identified HFE/Erg } \\
\text { Deficiencies }\end{array}$ & $\begin{array}{c}\text { Suggected HFE/Brg } \\
\text { Resolutions }\end{array}$ & $\begin{array}{l}\text { Rewolution prior to } \\
\text { Pro-operational } \\
\text { Tet \& Evaluation }\end{array}$ \\
\hline - & - & 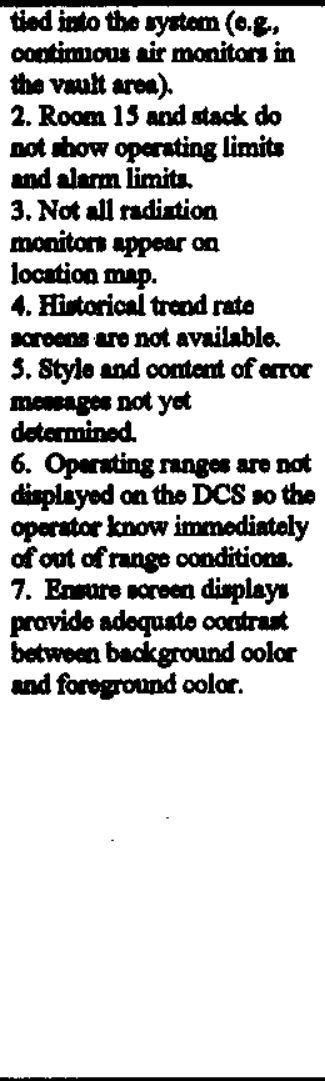 & 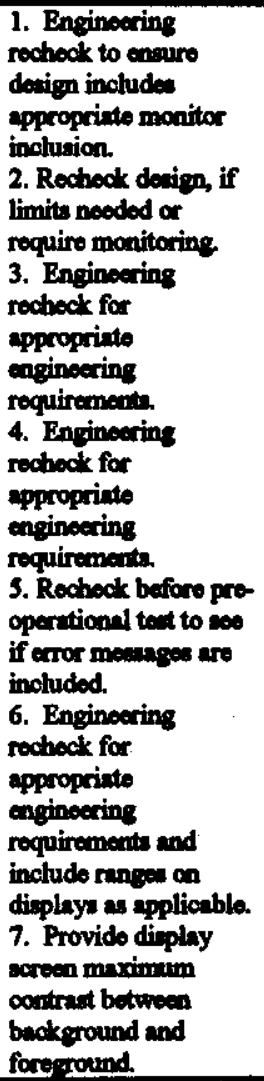 & 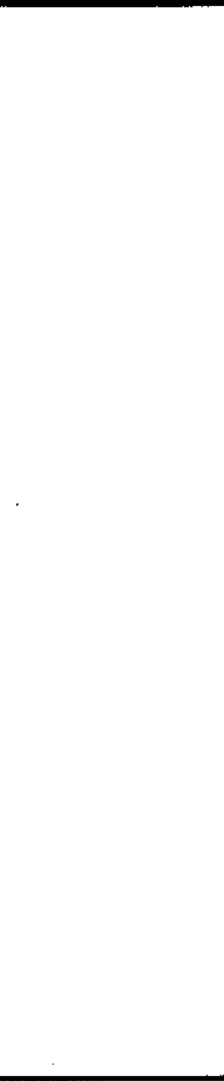 \\
\hline $\begin{array}{l}\text { Heating Vertilation, and } \\
\text { Air Conditioning System }\end{array}$ & 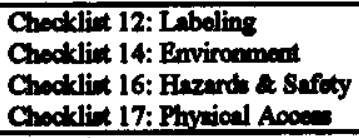 & $\begin{array}{l}\text { None identified (oxoollent } \\
\text { aymem deaign for HFE } \\
\text { maintainability } \\
\text { comidertions). }\end{array}$ & & \\
\hline $\begin{array}{l}\text { Gaseous Bffluent } \\
\text { Monitoring Syatem (GEMS) }\end{array}$ & 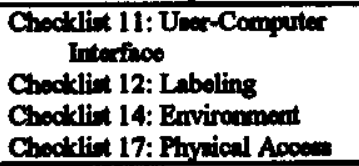 & $\begin{array}{l}\text { 1. minor obnervation of } \\
\text { powible kinking of bulk } \\
\text { aloctrioal wiring from wall } \\
\text { to unit. }\end{array}$ & $\begin{array}{l}\text { 1. Reroute wiring to } \\
\text { svoid kinking. }\end{array}$ & \\
\hline Commmioxtion Syctem & $\begin{array}{l}\text { Cheoklit 1: Operational Aida } \\
\text { Chooklist 7: Andio Dieplays } \\
\text { Chockllit 19: Commeniontion }\end{array}$ & None idertified & & \\
\hline
\end{tabular}

See Table A13-1 in KNF-3353, Anex A, for thow systems eclected wing Groded Appronch.

\subsection{REVIEW COMMENT RECORD}

Table 1-2 summarizes the review comment records (RCRs) that document questions and comments relevant to this supplemental report.. 
Table 1-2. Summary of Review Comment Record. (3 sheets)

\begin{tabular}{|c|c|c|c|}
\hline Item & Question/Comment Summary & Hold & Proposed Disposition \\
\hline 13-16 & $\begin{array}{l}\text { Major systems ignored for HFE evaluation are } \\
\text { HVAC, MCO mobile station hatch assembly, } \\
\text { Cask lifting yoke, rail frogs, instrument air } \\
\text { system, and continuos air monitoring system. } \\
\text { Perform HFE evaluations, including pertinent } \\
\text { HMI analysis, on the above listed systems. }\end{array}$ & $\mathbf{Y}$ & $\begin{array}{l}\text { HFE evaluations of the HVAC, MCO } \\
\text { mobile station hatch assembly, Cask lifting } \\
\text { yoke, rail frogs, instrument air system, and } \\
\text { continuos air monitoring system will be } \\
\text { accomplished, an incorporated into the } \\
\text { FSAR, as soon as possible. The } \\
\text { continuous air monitoring system is now } \\
\text { called the Gaseous Effluent Monitoring } \\
\text { System (GEMS). }\end{array}$ \\
\hline $13-18$ & $\begin{array}{l}\text { Similar to RCR 13-16. } \\
\text { Perform HFE evaluations, including pertinent } \\
\text { HMI analysis and using a graded approach } \\
\text { consistent with the system's hazards on all CSB } \\
\text { systems. Incorporate into FSAR. }\end{array}$ & $\mathbf{Y}$ & $\begin{array}{l}\text { A re-review of CSB systems will be } \\
\text { conducted and HFE evaluations, including } \\
\text { applicable Human-Machine Interface } \\
\text { (HMI) analysis, using a graded approach } \\
\text { consistent with the system hazards. This } \\
\text { re-review will be incorporated into the } \\
\text { FSAR via a proposed supplemental } \\
\text { abbreviated HFE Analysis Report of } \\
\text { Results and Findings. }\end{array}$ \\
\hline $13-19$ & $\begin{array}{l}\text { The CSB FSAR has not evaluated the lighting, } \\
\text { acoustical, and vibrational operating } \\
\text { environment, general hazards, and operating } \\
\text { safety of the CSB in spite of establishment of } \\
\text { numerous requirements on the operating } \\
\text { environment that should have provided the basis } \\
\text { for adequate HFE assessment. } \\
\text { Perform HFE assessment using the existing } \\
\text { requirements on lighting, vibration, noise, etc. } \\
\text { stated in DOE Order } 6430.1 \mathrm{~A}, \text { ANSI 57.2, and } \\
\text { other requirements. }\end{array}$ & $\mathbf{Y}$ & $\begin{array}{l}\text { The operating environment design will be } \\
\text { evaluated using available calculated } \\
\text { engineering design requirements and } \\
\text { compare the results to existing criteria } \\
\text { found in HFE standards through the use of } \\
\text { INEL-95/0117, Chocklist No. 14, Human } \\
\text { Factors Engineering Checklists for } \\
\text { Application in the SAR Process, } \\
\text { Environment. } \\
\text { This review will be incorporated into the } \\
\text { FSAR via a proposed supplemental } \\
\text { abbreviated HFE Analysis Report of } \\
\text { Results and Findings. }\end{array}$ \\
\hline $13-20$ & $\begin{array}{l}\text { The CSB FSAR HFE analysis is not complete, as } \\
\text { mumerous issues identified in the HFE foundation } \\
\text { analysis (SNF-3907) are shown as unresolved... } \\
\text { Identify the specific item(s) assumed by the HFE } \\
\text { to close an open issue and so list as necessary in } \\
\text { the FSAR. }\end{array}$ & $\mathbf{Y}$ & $\begin{array}{l}\text { Those apparent specific Human Design } \\
\text { Deficiencies (HEDs) items assumed to } \\
\text { close the HFE open issues will be carried } \\
\text { forward and listed in the FSAR. This will } \\
\text { also necessitate a re-review of the current } \\
\text { design, as changes to the design may affect } \\
\text { the HEDs table, i.e., what may have been a } \\
\text { HED at an earlier point in the design may } \\
\text { now be a moot commentary on the design. }\end{array}$ \\
\hline $13-21$ & $\begin{array}{l}\text { The CSB FSAR has not adequately evaluated } \\
\text { HFE impact on the hazards and accident analysis. } \\
\text { No assessment of this is presented in the FSAR at } \\
\text { all. }\end{array}$ & $\mathbf{Y}$ & $\begin{array}{l}\text { A re-review of the CSB hazard analysis } \\
\text { will be conducted, especially considering } \\
\text { design changes since the last review, and } \\
\text { results will be presented in the FSAR and } \\
\text { captured in the proposed supplemental } \\
\text { abbreviated HFE Analysis Report of } \\
\text { Results and Findings. }\end{array}$ \\
\hline
\end{tabular}


Table 1-2. Summary of Review Comment Record. (3 sheets)

\begin{tabular}{|c|c|c|c|}
\hline Item & Question/Comment Summary & Hold & Proposed Disposition \\
\hline & $\begin{array}{l}\text { Complete the HFE assessment of the CSB hazard } \\
\text { analysis and incorporate the consequent controls, } \\
\text { features, and other mitigations or prevention } \\
\text { means into the hazard analysis and show these } \\
\text { have been captured in Chapter 13A. }\end{array}$ & & \\
\hline $13-22$ & $\begin{array}{l}\text { Similar to RCR 13-16. } \\
\text { The foundation HFE analysis clearly states the } \\
\text { assessment is not complete, but no clear path to } \\
\text { closure was laid out in the FSAR, nor are } \\
\text { mechanisms described to ensure the issues picked } \\
\text { up by the HFE assessment will be closed. }\end{array}$ & $\mathbf{Y}$ & $\begin{array}{l}\text { A re-review of the CSB system will be } \\
\text { conducted, especially considering design } \\
\text { changes since the last review. Results will } \\
\text { be presented in the FSAR and captured in } \\
\text { the proposed supplemental abbreviated } \\
\text { HFE Analysis Report of Results and } \\
\text { Findings. }\end{array}$ \\
\hline $13-23$ & $\begin{array}{l}\text { CSB FSAR fails to state what design changes or } \\
\text { administrative features are necessary to } \\
\text { implement acceptable alternative means to meet } \\
\text { HFE criteria for the few systems evaluated. SNF } \\
3907 \text {, likewise, has not specifically identified } \\
\text { these, either. } \\
\text { List all design changes and administrative } \\
\text { controls determined to be nocessary from the } \\
\text { completed CSB HFE, including all systems, not } \\
\text { just the systems presently evaluated. Provide } \\
\text { justification for choice of these alternative over } \\
\text { compliance with the HFE roquirement. }\end{array}$ & $\mathbf{Y}$ & $\begin{array}{l}\text { A re-review of the CSB system will be } \\
\text { conducted, especially considering design } \\
\text { changes since the last review. Results will } \\
\text { be presented in the FSAR and captured in } \\
\text { the proposed supplemental abbreviated } \\
\text { HFE Analysis Report of Results and } \\
\text { Findings. }\end{array}$ \\
\hline $13-24$ & $\begin{array}{l}\text { Discussion has neither provided an adequate } \\
\text { summary of the HFE analysis for the MHM nor } \\
\text { any pertinent evaluation from SNF 3907, } \\
\text { Section 6.3. } \\
\text { Discussion has not incorporated the analyses } \\
\text { provided in FDH letters FDH-9755210R1 } \\
\text { (Mahaffey 1997), Item } 2 \text { of enclosure, or } \\
\text { FDH-9855462 (Maheffey 1998), Attachment } 2 .\end{array}$ & $\mathbf{Y}$ & $\begin{array}{l}\text { A re-review of the CSB MHM will be } \\
\text { conducted, especially considering design } \\
\text { changes since the last review. Results will } \\
\text { be presented in the FSAR and captured in } \\
\text { the proposed supplemental abbreviated } \\
\text { HFE Analysis Report of Results and } \\
\text { Findings. The letters will be captured in } \\
\text { the report. }\end{array}$ \\
\hline $13-25$ & $\begin{array}{l}\text { Discussion has not provided an adequate } \\
\text { summary of the HFE analysis on the receiving } \\
\text { crane. }\end{array}$ & $\mathbf{Y}$ & $\begin{array}{l}\text { A re-review of the CSB receiving crane } \\
\text { will be conducted, especially considering } \\
\text { design changes since the last review, and } \\
\text { results will be presented in the FSAR and } \\
\text { captured in the proposed supplemental } \\
\text { abbreviated HFE Anatysis Report of } \\
\text { Results and Findings. }\end{array}$ \\
\hline $13-26$ & $\begin{array}{l}\text { Discussion has not provided an adequate } \\
\text { summary of the HFE analysis on the vent/purge } \\
\text { carts. No HFE has apparently been done on the } \\
\text { carts. } \\
\text { Release of the carts for installation or use in the } \\
\text { CSB is withheld pending submission, review, and } \\
\text { approval of their HFE analysis. }\end{array}$ & $\mathbf{Y}$ & $\begin{array}{l}\text { HFE analysis of the Vent/Purge Cart } \\
\text { design is completed, including interview } \\
\text { with the design engineer. Results will be } \\
\text { presented in the FSAR and captured in the } \\
\text { proposed supplemental abbreviated HFE } \\
\text { Analysis Report of Results and Findings. }\end{array}$ \\
\hline
\end{tabular}


Table 1-2. Summary of Review Comment Record. (3 sheets)

\begin{tabular}{|c|l|l|l|}
\hline Item & \multicolumn{1}{|c|}{ Question/Comment Summary } & Hold & \multicolumn{1}{|c|}{ Proposed Disposition } \\
\hline 13-27 & $\begin{array}{l}\text { CSB FSAR fails to describe an adequate staffing } \\
\text { plan for the CSB and does not show adequate } \\
\text { consideration of HFE in those staffing plans. No } \\
\text { requirements have been stated. Provide specific } \\
\text { staffing plan for the CSB and show it meets } \\
\text { stated requirements. }\end{array}$ & N & $\begin{array}{l}\text { A specific CSB staffing plan will be } \\
\text { provided with consideration of applicable } \\
\text { HFE requirements based on systematic job } \\
\text { and task analyses. Results will be presented } \\
\text { in the FSAR and captured in the proposed } \\
\text { supplemental abbreviatod HFE Analysis } \\
\text { Report of Results and Findings. }\end{array}$ \\
\hline 13-28 & $\begin{array}{l}\text { CSB FSAR fails to show adequate HFE } \\
\text { considerations for abnorimal facility operations. } \\
\text { No specific recovery actions are listed anywhere } \\
\text { in the FSAR. }\end{array}$ & Y & $\begin{array}{l}\text { A HFE re-evaluation of the CSB proposed } \\
\text { abnormal facility operations will be } \\
\text { accomplished. Results will be presented in } \\
\text { the FSAR and captured in the proposed } \\
\text { supplemental abbreviated HFE Analysis } \\
\text { Report of Results and Findings. }\end{array}$ \\
\hline
\end{tabular}

\subsection{PROCEDURE FOR THIS ABBREVIATED REPORT}

The procedure used in developing this supplemental abbreviated HFE/Erg report is as follows:

a) Review the RCRs and Dispositions associated with the FSAR, CSB Annex A FSAR, and the information and data found in SNF-3907

b) Interview the applicable project management and system engineers to obtain data, engineering drawings, or available mock-ups (if any), and information

c) Tour the CSB facility to see what is currently in place and design progress

d) Evaluate CSB facility and operational systems using a graded approach

e) Write a report on evaluations and findings to update the FSAR.

This report will be limited to the goal of satisfying the disposition to the RCRs. The report will fill in the gaps left from SNF-3907. The foundation work has already been described in SNF-3907 and will not be repeated in this report. Refer to SNF-3907 for the technical background, methodology of the FSAR analysis, and initial system analyses conducted, for the CSB HFE work. 


\section{SNF-4831 REV 0}

\subsection{HUMAN FACTORS ENGINEERING AND ERGONOMICS GRADED APPROACH}

For the CSB, important-to-safety structures, systems, and components (SSCs) have been identified in accordance with 10 CFR 72.3, "Licensing Requirements for the Independent Storage of Spent Nuclear Fuel and High-Level Radioactive Waste (10 CFR 72) (see HNF-3553, Annex A, Chapter A4.0). Once SSCs have been identified as having a function meeting the definition of "important-to-safety," the requirements for SSCs important to safety specified in 10 CFR 72 are imposed. A graded approach is applied to an SSC important-to-safety by using the guidance provided in NUREG/CR-6407, Classification of Transportation Packaging and Dry Spent Fuel Storage Systems, as follows:

- Category A - Critical to Safe Operation

SSCs in this category include those whose failures or malfunction could directly result in a condition adverse to public health and safety. Important-to-safety SSCs in this category are classified as safety class as defined in DOE Order 6430.1A, General Design Criteria, with the additional requirements therein.

- Category B - Major Impact on Safety

SSCs in this category include those whose failures or malfunctions could result in a condition adversely affecting collocated worker health and safety. Note that from the definition of Category C, Category B is understood to include events that could significantly damage the $\mathrm{MCO}$ without severe impact to public health and safety. SSCs in this category are classified as safety significant as defined in DOE-STD3009-94, Preparation Guide for U.S. Department of Energy Nonreactor Nuclear Facility Safety Analysis Reports.

- Category C - Minor Impact on Safety

SSCs whose failure or malfunction would not significantly reduce containment and would not be likely to create a situation adversely affecting public or collocated worker's health and safety. SSCs in this category are classified as safety class 3 (nonsafety) as defined in DOE Order 6430.1A.

Graded Approach means a process by which the level of analysis, documentation, and actions necessary to comply with a requirement are generally commensurate with the following:

a) The relative importance to safety, safeguards, and security

b) The magnitude of any hazard involved

c) The life cycle stage of a facility

d) The programmatic mission of a facility 


\section{SNF-4831 REV 0}

e) The particular characteristics or complexity of a facility

f) Any other relevant factor.

Hazard means a source of danger (i.e., material, energy source, or operation) with the potential to cause illness, injury, or death to personnel or damage to a facility or to the environment (without regard to the likelihood or credibility of accident scenarios or consequence mitigation).

Whenever a graded approach is applied in meeting a DOE nuclear safety requirement, the bases for selecting an action pursuant to the graded approach must be documented. The grading used must assure that the level of effort necessary to create and maintain a SAR, the sophistication of the analyses that go into the preparation of the SAR, and the thoroughness of the documentation in the HFE/Erg SAR should all be proportioned to the degree of human-facility interaction and the above listed factors (a through $\mathrm{f}$ ).

New facilities, such as the CSB, would subscribe to HFE/Erg using the systems approach to design which pledges that SSCs, will be built in accordance with the best design practices given the available resources of time and money. The SNF Project has determined that the graded approach is a requirement for the CSB facility. One HFE/Erg interpretation of the graded approach was developed in SNF-3907, Section 1.4, "HFE SAR Analysis Technical Approach." This approach is maintained, as appropriate, for this report for consistency between the two reports. The approach used in this report is summarized as follows:

a) $\mathrm{HFE} / \mathrm{Erg}$ engineering analysis considers the HFE requirements of DOE Order 5480.23, Attachment 1, Section 14, commensurate with: (1) planned Spent Nuclear Fuel (SNF) project mission, (2) hazard category 2 classification, (3) level of complexity of the SNF project operations, and (4) the type of human operations or interactions with the SSCs

b) Conduct applicable tabletop task analysis, direct interview with project management and cognizant engineers, reviewing existing hardware and software, and system design documents

c) Analyze applicable system(s) using INEL-95/0117, Human Factors Engineering Checklists for Application in the SAR Process

d) Apply HFE/Erg criteria or guidelines to components not completely physically assembled

e) Review the hazard analysis to determine whether human operator actions involve using equipment or taking action that must be further analyzed.

In evaluating the CSB structure and operations (systems and components) important to safety, the HFE/Erg graded approach was applied to determine those systems requiring an in-depth HFE/Erg analysis, either to provide design considerations to the engineers during design work, or to determine that those systems already established meet HFE/Erg criteria. Table 1-3, 
Summary Analysis of HFE/Erg Graded Approach, summarizes the CSB structure, SSCs important to safety and shows how the graded approach was applied in determining which system required further analysis with focus on HFE/Erg.

Table 1-3. Summary Analysis of HFE/Erg Graded Approach. (4 sheets)

\begin{tabular}{|c|c|c|c|}
\hline $\begin{array}{l}\text { Canister Storage Building } \\
\text { Structures, Systems } \\
\text { or Components } \\
\text { Important to Safety }\end{array}$ & $\begin{array}{l}\text { Safety Consideration and } \\
\text { Safety Classification }\end{array}$ & $\begin{array}{l}\text { Significant Human- } \\
\text { Machine/Facility } \\
\text { Interface }\end{array}$ & $\begin{array}{l}\text { Selected for Human } \\
\text { Factors Engineering } \\
\text { and Ergonomics } \\
\text { Anatysis using } \\
\text { Graded Approach }\end{array}$ \\
\hline $\begin{array}{l}\text { CSB subsurface structure } \\
\text { (including the basemat, vault, } \\
\text { inlet plenum and outlet } \\
\text { plemum) }\end{array}$ & $\begin{array}{l}\text { Safety Class } \\
\text { Important-to-Safety } \\
\text { Category A }\end{array}$ & No & No \\
\hline $\begin{array}{l}\text { At-grade reinforced concrete } \\
\text { deck structure (operating deck, } \\
\text { intake structure, and exhaust } \\
\text { structure) }\end{array}$ & $\begin{array}{l}\text { Safety Class } \\
\text { Important-to-Safety } \\
\text { Category A }\end{array}$ & No & No \\
\hline $\begin{array}{l}\text { Standard storage tube and tube } \\
\text { base assembly }\end{array}$ & $\begin{array}{l}\text { Safety Class } \\
\text { Important-to-Safety } \\
\text { Category A }\end{array}$ & No & No \\
\hline $\begin{array}{l}\text { Bottom impact absorber } \\
\text { (storage tube) }\end{array}$ & $\begin{array}{l}\text { Safety Class } \\
\text { Important-to-Safety } \\
\text { Category A }\end{array}$ & No & No \\
\hline Standard storage tube plugs & $\begin{array}{l}\text { Safety Significant } \\
\text { Important-to-Safety } \\
\text { Category B }\end{array}$ & No & No \\
\hline Intermediate impact absorber & $\begin{array}{l}\text { Safety Significant } \\
\text { Important-to-Safety } \\
\text { Category B } \\
\end{array}$ & No & No \\
\hline Support area building & $\begin{array}{l}\text { Safety Significant } \\
\text { Important-to-Safety } \\
\text { Category B }\end{array}$ & Yes & Yes \\
\hline $\begin{array}{l}\text { Receiving crane } \\
\text { positioning/interlock control } \\
\text { system, receiving crane lifting } \\
\text { yoke }\end{array}$ & $\begin{array}{l}\text { Safety Class } \\
\text { Important-to-Safety } \\
\text { Category A }\end{array}$ & Yes & Yes \\
\hline $\begin{array}{l}\text { Receiving crane structure and } \\
\text { hoist }\end{array}$ & $\begin{array}{l}\text { Safety Significant } \\
\text { Important-to-Safty } \\
\text { Category B }\end{array}$ & No & No \\
\hline Service station impact absorber & $\begin{array}{l}\text { Safety Class } \\
\text { Important-to-Safety } \\
\text { Category A }\end{array}$ & No & No \\
\hline $\begin{array}{l}\text { Multi-canister overpack } \\
\text { handling machine (MHM) rails }\end{array}$ & $\begin{array}{l}\text { Safety Class } \\
\text { Important-to-Safety } \\
\text { Category A }\end{array}$ & No & No \\
\hline Rail frogs & Safety Class & Yes & Yes \\
\hline
\end{tabular}


Table 1-3. Summary Analysis of HFE/Erg Graded Approach. (4 sheets)

\begin{tabular}{|c|c|c|c|}
\hline $\begin{array}{l}\text { Canister Storage Building } \\
\text { Structures, Systems } \\
\text { or Components } \\
\text { Important to Safety }\end{array}$ & $\begin{array}{l}\text { Safety Consideration and } \\
\text { Safety Classification }\end{array}$ & $\begin{array}{l}\text { Significant Human- } \\
\text { Machine/Facility } \\
\text { Interface }\end{array}$ & $\begin{array}{l}\text { Selected for Human } \\
\text { Factors Engineering } \\
\text { and Ergonomics } \\
\text { Analysis using } \\
\text { Graded Approach }{ }^{3}\end{array}$ \\
\hline & $\begin{array}{l}\text { Important-to-Safety } \\
\text { Catogory A }\end{array}$ & & \\
\hline $\mathrm{MCO}$ and transportation cask & $\begin{array}{l}\text { Safety Class } \\
\text { Important-to-Safety } \\
\text { Category A }\end{array}$ & No & Yes \\
\hline Cask transfer safety system & $\begin{array}{l}\text { Safety Significant } \\
\text { Important-to-Safety } \\
\text { Category B }\end{array}$ & No & Yes \\
\hline $\begin{array}{l}\text { Transportation cask shielding } \\
\text { and the MCO shield plug } \\
\text { shielding }\end{array}$ & $\begin{array}{l}\text { Safety Significant } \\
\text { Important-to-Safety } \\
\text { Category B }\end{array}$ & No & No \\
\hline $\begin{array}{l}\text { MCO service station pit and } \\
\text { shield hatch assembly }\end{array}$ & Safety Significant & No & No \\
\hline $\begin{array}{l}\text { Mobile service station tont, tent } \\
\text { gantry hoist, and equipment }\end{array}$ & General Service & No & No \\
\hline $\begin{array}{l}\text { Mobile service station tent } \\
\text { gantry hoist }\end{array}$ & $\begin{array}{l}\text { Important to Safety } \\
\text { Category C }\end{array}$ & Yes & Yes \\
\hline $\begin{array}{l}\text { MCO flex connector, high- } \\
\text { efficiency particulate air } \\
\text { (HEPA) filter and piping } \\
\text { between the filter and cask }\end{array}$ & Safety Significant & No & Yes \\
\hline MCO servicing instruments & General Service & Yes & Yes \\
\hline MCO tube vent/purge cart & Safety Significant & Yes & Yes \\
\hline $\begin{array}{l}\text { MHM interface guide ring; } \\
\text { MHM seismic restraints; } \\
\text { MHM interlocks preventing } \\
\text { translational shear; } \\
\text { MHM interlocks preventing } \\
\text { turret rotation when the MCO } \\
\text { hoist is not fully raised; } \\
\text { MHM seismic detection and } \\
\text { power-disconnect system; } \\
\text { MHM interlocks that prevent } \\
\text { rotating the turret to the MCO } \\
\text { position when over the } \\
\text { maintenance pit; and } \\
\text { MHM interlocks that ensure the } \\
\text { MHM turret is rotated to the }\end{array}$ & $\begin{array}{l}\text { Safety Class } \\
\text { Important-to-Safety } \\
\text { Category A }\end{array}$ & No & No \\
\hline
\end{tabular}


Table 1-3. Summary Analysis of HFE/Erg Graded Approach. (4 sheets)

\begin{tabular}{|c|c|c|c|}
\hline $\begin{array}{l}\text { Canister Storage Building } \\
\text { Structures, Systems } \\
\text { or Components } \\
\text { Important to Safety }\end{array}$ & $\begin{array}{l}\text { Safety Consideration and } \\
\text { Safety Classification }\end{array}$ & $\begin{array}{l}\text { Significant Human- } \\
\text { Machine/Facility } \\
\text { Interface }\end{array}$ & $\begin{array}{l}\text { Selected for Human } \\
\text { Factors Engineering } \\
\text { and Ergonomics } \\
\text { Analysis using } \\
\text { Graded Approach }{ }^{3}\end{array}$ \\
\hline \multicolumn{4}{|l|}{$\begin{array}{l}\text { navigate position before } \\
\text { allowing power to the bridge or } \\
\text { trolley drive motor }\end{array}$} \\
\hline $\begin{array}{l}\text { MHM collision-avoidance } \\
\text { system (interlock P10); } \\
\text { MHM radiation protection } \\
\text { interlock system } \\
\text { MHM fixed shielding }\end{array}$ & Safety Significant & No & No \\
\hline $\begin{array}{l}\text { MHM structure } \\
\text { MHM MCO hoist }\end{array}$ & $\begin{array}{l}\text { Safety Significant } \\
\text { Important-to-Safety } \\
\text { Category B }\end{array}$ & No & No \\
\hline $\begin{array}{l}\text { MHM closed-circuit television } \\
\text { (CCTV) system }\end{array}$ & General Service & Yes & Yes \\
\hline $\begin{array}{l}\text { MFM Operations "Control } \\
\text { Room" }\end{array}$ & General Service & Yes & Yes \\
\hline $\begin{array}{l}\text { Remaining components of } \\
\text { MHM and the anticollision } \\
\text { system }\end{array}$ & General Service & No & Yes \\
\hline Sampling station chiller & General Service & No & No \\
\hline Sampling/weld station & $\begin{array}{l}\text { Safety Class } \\
\text { Important-to-Safety } \\
\text { Category A } \\
\end{array}$ & Yes & Yes \\
\hline $\begin{array}{l}\text { Sampling/weld station MCO } \\
\text { support system (at station) }\end{array}$ & $\begin{array}{l}\text { Safety Class } \\
\text { Important-to-Safety } \\
\text { Category A }\end{array}$ & No & No \\
\hline $\begin{array}{l}\text { Sample/weld station impact } \\
\text { absorbers }\end{array}$ & $\begin{array}{l}\text { Safety Class } \\
\text { Important-to-Safety } \\
\text { Category A } \\
\end{array}$ & No & No \\
\hline $\begin{array}{l}\text { Sample/weld station Helium } \\
\text { pressure safety valves (PSV) } \\
\mathbf{7 2 0} \text { and } 728\end{array}$ & $\begin{array}{l}\text { Safety Class } \\
\text { Important-to-Safety } \\
\text { Category A }\end{array}$ & No & No \\
\hline $\begin{array}{l}\text { MCO sampling equipment } \\
\text { (sample hood and HEPA filter, } \\
\text { exhaust system (HEPA filter), } \\
\text { sample hood exhaust flow } \\
\text { indicator), cooling cap }\end{array}$ & Safety Significant & Yes & Yes \\
\hline
\end{tabular}


Table 1-3. Summary Analysis of HFE/Erg Graded Approach. (4 sheets)

\begin{tabular}{|c|c|c|c|}
\hline $\begin{array}{l}\text { Canister Storage Building } \\
\text { Structures, Systems } \\
\text { or Components } \\
\text { Important to Safety }\end{array}$ & $\begin{array}{l}\text { Safety Consideration and } \\
\text { Safety Classification }{ }^{1}\end{array}$ & $\begin{array}{l}\text { Significant Human- } \\
\text { Machine/Facility } \\
\text { Interface? }\end{array}$ & $\begin{array}{l}\text { Selected for Human } \\
\text { Factors Engineering } \\
\text { and Ergonomics } \\
\text { Analysis using } \\
\text { Graded Approach } \\
\text { 3 }\end{array}$ \\
\hline $\begin{array}{l}\text { Sampling/weld station test } \\
\text { equipment (welding equipment } \\
\text { and weld diagnostics } \\
\text { equipment, sampling cart and } \\
\text { tools, including long reach } \\
\text { tools }\end{array}$ & General Service & Yes & Yes \\
\hline $\begin{array}{l}\text { Passive cooling of the Canister } \\
\text { Storage Building storage vault } \\
\text { intake stack, intake } \\
\text { plemum/exhaust plenum, } \\
\text { exhaust stack and vault }\end{array}$ & $\begin{array}{l}\text { Safety Class } \\
\text { Important-to-Safety } \\
\text { Category A }\end{array}$ & No & No \\
\hline DCS & General Service & No & Yes \\
\hline Fire protection system & General Service & No & No \\
\hline $\begin{array}{l}\text { Heating, Ventilation \& Air } \\
\text { Conditioning system (HVAC) }\end{array}$ & General Service & No & Yes \\
\hline Health protection system & General Service & No & No \\
\hline $\begin{array}{l}\text { Airborno emissions monitoring } \\
\text { system GEMS }\end{array}$ & General Service & No & Yes \\
\hline $\begin{array}{l}\text { Inert gas supply system, helium } \\
\text { supply system pressure safety } \\
\text { valves (PSV-720 and PSV-728) }\end{array}$ & $\begin{array}{l}\text { Safety Class } \\
\text { Important-to-Safety } \\
\text { Category A } \\
\end{array}$ & No & No \\
\hline $\begin{array}{l}\text { Remainder of helium supply } \\
\text { system }\end{array}$ & General Service & No & No \\
\hline $\begin{array}{l}\text { Seismic detection system for } \\
\text { the MHM, for the receiving } \\
\text { crane and the MHM and the } \\
\text { power-disconnect system for } \\
\text { the MHM }\end{array}$ & \begin{tabular}{|l} 
Safety Class \\
Important-to-Safety \\
Category A
\end{tabular} & No & No \\
\hline Normal eloctrical power system & General Service & No & No \\
\hline $\begin{array}{l}\text { Instrument air and Service air } \\
\text { system }\end{array}$ & General Service & No & No \\
\hline Liquid waste collection system & General Service & No & No \\
\hline Sanitary water system & General Service & No & No \\
\hline Communication system & General Service & Yes & Yes \\
\hline
\end{tabular}

Notes:

${ }^{1}$ Systems safety classes categorized from HNF-3553, Rev. 0, Annex A - Canister Storage Building, Chapter A4.0 or Chapter A2.0.

${ }^{2}$ Significant HMI includes either operation of system or maintenance of system, or both operation and maintenance of system.

${ }^{3}$ A system may not have significant HMI, but was selected for evaluation of limited HMI following system installation. 


\subsection{CANISTER STORAGE BUILDING FACILITY DESCRIPTION AND OPERATING SYSTEM OVERVIEW}

This section will briefly describe the CSB facility and operating systems contained with the CSB facility (see HNF-3553, Annex A, Chapter A2.0, "Facility Description," for the detailed description of the CSB facility). It is necessary to understand the facility description because the assumptions lead directly to supporting the hazard and accident analyses. HNF-3553, Annex A, Chapter A3.0, "Hazard Analysis," describes the hazards, accident analyses, and safety classifications of the SSCs for the CSB; Chapter A4.0 describes the safety-class and safetysignificant SSCs in detail and also identifies safety controls (the technical safety requirements) for the facility.

\subsection{CANISTER STORAGE BUILDING}

The CSB (see Figure 2-1, Canister Storage Building) comprises and provides a steelframe facility that encloses the operating area. The operating area is used for receiving, sampling, monitoring, welding, staging, and interim storage of MCOs. The MCOs are stored in one of the three below-grade (underground) vaults. The below-grade vaults, designed for ambient aircooling ventilation, will be inaccessible to humans after construction is complete.

Support functions and equipment are housed in a steel-frame support area (support building) on the north side of the operations building. Only the northernmost vault (vault 1) is equipped with steel tubes for staging of mechanically sealed MCOs and storage of the MCOs having welded caps. The other vaults are reserved for future projects.

The CSB detailed design involved considerable shielding analysis and design because of the radioactive SNF. The SNF is to be contained in the MCOs, which are dry stored in the storage tubes of the CSB. Before being received at the CSB, the SNF, within the MCO, is cold vacuum dried to remove as much of the residual water from the $K$ Basins pools as possible. This is done because a major safety concern is the generation of hydrogen gas from both the radiolysis of the residual water and the chemical reactions of the water with the SNF materials. MCOs, within transportation casks, are received at the CSB by way of truck. Transportation cask weight is limited by the 30-ton lifting capacity of the $\mathrm{K}$ Basins crane. Therefore, the transportation cask design only provides about $7.6 \mathrm{in}$. of steel for the side thickness, resulting in a worst case dose rate of about $50 \mathrm{mrem} / \mathrm{h}$ on contact at the mid-height cask surface. This higher than acceptable dose rate for the CSB has resulted in additional shielding requirements for the CSB and associated MCO handling equipment. The additional shielding requirements have the greatest effect on human operations, especially in handling of the MCOs. For example, the necessary shielding impairs the crane operator's view during receiving, which will be discussed later in this report.

\subsubsection{CSB Subsurface Structures}

The below-grade portion of the CSB will be inaccessible to the operators. This information is presented to provide an understanding of the CSB facility and shielding 
requirements. The CSB subsurface structure (including the basemat, vault, inlet plenum, and outlet plemum) are classified as safety class and important-to-safety Category A.

The below-grade reinforced concrete portion of the CSB is composed of the basemat, three vaults, inlet plenums and exhaust plenums. The floor area encompassing the load-in/loadout area, operating area, and sampling/weld area is approximately $230 \mathrm{ft}$ long by $137 \mathrm{ft}$ wide. The operating floor is enclosed by a steel-framed building and the operating area shelter.

Only vault 1 , the northernmost vault, has carbon steel storage tubes and an individual intake structure and exhaust stack in order to expedite the receipt of MCOs containing SNF. The intake structures and exhaust stacks for the other two vaults, except the intake and exhaust stack bases, have not been constructed and are outside the scope of the SNF Project FSAR.

The below-grade walls and basemat carry the loads associated with handling and transporting the MCOs (i.e., transporter with cask, receiving crane, and MHM.

The inlet and outlet plenums are concrete ducts providing for air flow into and out of the vaults. The CSB below-grade structure provides shielding for the inlet and outlet plenums. The subsurface structure, with 3-ft thick interior walls, provide shielding from the source term associated with SNF storage.

\subsubsection{At-Grade Reinforced Concrete Structures}

The at-grade concrete structure includes the operating deck, the intake structure, the exhaust structure, and the perimeter curb. The design of the at-grade reinforced concrete deck structure (operating deck, intake structure, and exhaust structure) is classified as safety-class and important-to-safety Category A.

The operating deck is a 5-ft thick reinforced concrete structure that forms the at-grade portion of the CSB (see Figure 2-2, CSB Operating Deck Plan View). The dimensions of the operating deck are approximately $230-\mathrm{ft}$ north-south by $137-\mathrm{ft}$ east-west. The operating area deck floor is bounded to the north by the load-in/load-out area (trailer vestibule and MCO service station) and support area building foundations, and to the south by the sampling/weld area foundation. The operating deck structure contains numerous through-thickness steel sleeves (embeds) that receive the storage tubes and tube plugs for both the standard storage tube and the overpack storage tube locations in vault 1 . They also provide a location for the tube cover plates in vault 1 or deck embed cover plates in vaults 2 and 3 . These embeds are offset and arranged at a center-to-center distance of $4 \mathrm{ft}, 8 \mathrm{in}$. east-west and $4 \mathrm{ft}, 6 \mathrm{in}$. north-south. This distance between MCOs has been evaluated for criticality prevention and found to be adequate (see HNF3553, Annex A, Chapter A6.0). Two hundred twenty standard and six overpack embeds are provided for in each of the three vaults.

The sampling/weld area is an extension to the south of the operating deck. Its foundation is a reinforced concrete structure that houses process module mounting plates and seven process pits for sampling and welding (future) equipment. The dimensions of the sampling/weld area are $35 \mathrm{ft}, 3 \mathrm{in}$. by $138 \mathrm{ft}, 11 \mathrm{in}$. by $5 \mathrm{ft}$ thick. The reinforced concrete slab is supported at grade. 
A loading/staging vestibule is located on the west side of the sampling/weld area for egress and ingress of equipment. The dimensions of the loading/staging vestibule foundation are $24 \mathrm{ft}, 11 \mathrm{in}$. by $27 \mathrm{ft}, 4 \mathrm{in}$.. An outer and an inner door in the loading or staging vestibule serve as an air-lock for area ventilation confinement.

The load-in/load-out area is an extension to the north of the operating deck. This area houses an MCO service station pit and lines and provides trenches and anchor bolts for the rails serving the receiving crane, service station enclosure, and tent gantry hoist. The load-in/load-out area reinforced concrete slab is $138 \mathrm{ft}, 4 \mathrm{in}$. by $29 \mathrm{ft}, 9.5$ in. by $5 \mathrm{ft}$ thick, supported at grade. A trailer vestibule forms an extension to the west of the load-in/load-out area. The dimensions of the trailer vestibule slab are $42 \mathrm{ft}, 7$ in. by $50 \mathrm{ft}, 9.5$ in. by $5 \mathrm{ft}$ thick. This reinforced concrete slab is supported at grade. An outer door and an inner door in the trailer vestibule serve as an air-lock for operating area ventilation confinement. Two additional service pits are provided in the CSB load-in/load-out area. The easternmost pit is for MHM maintenance, and the center pit was designed for future transloading removal of Fast Flux Test Facility (FFTF) fuels from a transportation cask. A 10-ton screw jack assembly, mounted on the floor at the west end of the MHM maintenance pit, supports, elevates, and lowers the MHM mounting ring assembly and retractable nose assembly during maintenance operations.

Surrounding the operating area on the south, east, and west is a 4-ft, 4-in. -thick by 3-fthigh concrete perimeter curb. The curb is $2 \mathrm{ft}$ wide and $8 \mathrm{ft}$ high at the north wall of the loadin/load-out area for shielding support area building personnel from the MCO transportation cask. Doors are provided for personnel traffic through this shield wall.

\subsubsection{Canister Storage Building Steel Structures}

Storage tubes are located under the operating floor, accessed through the top of the operating deck, and supported from the basemat by a tube base assembly. The storage tubes are used to provide a controlled, confined environment to vertically store MCOs. There are two types of tube assemblies. A standard storage tube assembly has been installed through each of the 220 standard embed openings in the operating deck. An overpack storage tube assembly has been installed through each of the six overpack embed openings in the operating deck. The overpack storage tube assemblies provide a sealed confinement function in addition to a structural function. Overpack storage tube assemblies are provided in vault 1 for potential future use to store and monitor suspect MCOs.

The standard tube plug assembly provides radiation shielding and allows access to the tube interior for gas monitoring through a quick-disconnect fitting. The overpack tube plug assembly provides radiation shielding; holds gas pressure in the overpack storage tube; and allows access to the tube interior for gas inerting, and gas pressure monitoring. The standard and overpack tube plugs provide confinement of the MCOs. The tube plug has a cast steel top and concrete lower portion.

Tube plug covers protect the tube plug connections and devices and fit flush with the operation deck. The tube plug covers are 3-in. thick carbon steel disks provided with lifting lugs and a concentric inspection port for tube servicing operations and tube pressure monitoring. The 
deck embed covers in vaults 2 and 3 are 0.5 -in.-thick carbon steel plates designed with tube steel reinforcement and with gaskets at deck embed contact surfaces. The deck embed covers provide for personnel safety and maintain a level floor surface.

An impact absorber is located in the MCO service station in the load-in/load-out area to elevate the transportation cask, absorb the impact of a dropped cask, and align it with the top of the operating deck. Steel cask guides are located inside the MCO service station pit to align the cask with the shield hatch assembly. The impact absorber assemblies are held together by three stainless steel aircraft cables with a slight tension to hold the components together. In the event that the impact absorber is crushed, the aircraft cables remain intact so that the entire absorber can be removed from the storage tube.

The standard storage tube and tube base assembly are classified as safety class and important-to-safety Category A. The bottom impact absorber is classified as safety class and important-to-safety Category A. The standard storage tube plugs and intermediate impact absorber are classified safety significant. The intermediate impact absorber is important-to-safety Category B.

\subsubsection{Canister Storage Building Above-Grade Structures}

The support area building is classified as safety significant. The foundations and superstructure of the support area building are structurally isolated from the CSB vaults and operating shelter. The building houses equipment for electrical, HVAC, continuous airborne effluent monitors (gaseous effluent monitoring system or GEMS), facility operations monitoring, and change rooms. A 28-in.-diameter, 75-ft-high steel heating, ventilating, and air-conditioning (HVAC) exhaust stack, supported at grade with a guyline at the roof, penetrates through the building roof.

The exterior siding and roofing for the support area building is of equal grade and finish appearance to the operating area shelter. The siding and exterior wall design for the support area building is the same as described for the operating shelter. A relatively small telescoping door on the west side ( $10 \mathrm{ft}$ by $10 \mathrm{ft}$ ) opens to receive supplies into, and discharge waste from, the support area building. Warning indicators (rotating beacon and alarm bell) located on the west building exterior near the telescoping door are activated when the door is moving.

The primary personnel entrance for the CSB is at the northeast corner of the support area building near the health physics technician (HPT) office, control room, and operations office. A main corridor crosses the entire support area building between the primary personnel entrance on the east and the loading dock on the west. This corridor provides an exit path to the primary support area building exits.

Operating personnel enter the primary personnel entrance, don protective clothing in the change room, and enter the operating area shelter from an airlock in the support area building. Personnel return from the operating area shelter by a similar path, passing through a portal contamination monitor, for clothing removal, decontamination, and egress. Personnel may access the HPT and operations offices, change and control rooms, and various other rooms through 12 
single-wide interior personnel doors, and 1 double-wide interior pair of doors. All doors (airlock and personnel) have air seals around the jambs. They are rated for at least $20 \mathrm{lb} / \mathrm{ft}^{2}$ pressure and for $30 \mathrm{lb} / \mathrm{ft}^{2}$ pressure in the operating area. The HPT office has a view window to the personnel decontamination area.

The personnel monitoring and decontamination room, count room, step-off pad, and regulated change room areas have a depressed floor level with an access floor aligned with the surrounding finished floor. The flooring in these access floor areas has perforations to allow sprinkler discharge to accumulate in the depressed areas until the discharge can be decontaminated and removed.

The sealed exposed concrete floors and sealed horizontal surfaces of the equipment pads are waterproofed. The sealed surfaces resist liquid intrusion, aid in preventing contamination of the concrete surfaces, and reduce future decontamination and decommissioning labor by minimizing contamination of the concrete. Sumps are provided in the generator rooms, the HVAC equipment room, and mechanical equipment rooms. Curbs and exterior access-only doors to the generator rooms ensure that liquids (fire sprinkler actuation) will collect and drain away from the support area building.

Entry to the electrical room is through one tall exterior double door ( $6 \mathrm{ft}$ by $9 \mathrm{ft}$ ) with a removable top transom that allows equipment installation and servicing. Two similar, though shorter, standard height ( $6 \mathrm{ft}$ by $7 \mathrm{ft}$ ) pairs of exterior service doors provide access to the two generator rooms. The generator rooms also have wall louvers. The room containing the GEMS and the safeguards and security equipment is accessible from inside.

Part of the helium supply line is routed through the south side of the compressor area. There are two doorways separating this line from the control room (approximately $60 \mathrm{ft}$ ) where operators are stationed. This is sufficient distance to protect the operators should a helium leak occur in the supply line.

The inert gas system piping and components located inside the CSB support and operations area are designed to ASME B31.3, Process Piping Code, standards for the safetysignificant portions that connect to the MCO servicing system. The general service portions that supply inert gas to the vent and purge cart refill station and to the helium letdown station adhere to ASME B31.1-1992, Power Piping Code standards.

The seismic power trip eliminates potential failures resulting from seismic initiated electrical failures of the non-seismically qualified control system. The trip circuit is located in the power supply to the MHM and includes three tri-axial accelerometers connected to redundant power contactors in series. Any of nine sensors can cause both contactors to open. Only one contactor functioning will open the power circuit to the MHM. The initial trip setting will be onethird of the maximum horizontal or vertical spectra for the $0.35 \mathrm{~g}$ earthquake with $7 \%$ damping as calculated for the mounting location in the load-in/load-out area. This setting is based on U.S. Nuclear Regulatory Commission (NRC) criteria for the initiation of seismic monitoring. The panel containing this equipment is rigidly mounted and seismically qualified. 
Acoustical features provided for the control room in the support area include a suspended acoustical tile ceiling and sound board, which is installed on separate metal stud-framed wall partitions on both sides of the wall adjoining the empty generator room. The acoustical features are provided to comply with the requirements of DOE Order 6430.1A, Section 950, "Acoustical Treatment."

Grounding cables connect the support area building to the CSB ground grid, an underground wire cable system for protecting the CSB and its support structures from electrical hazards. The lighting rods on the CSB stack also protect the support area building in accordance with National Fire Prevention Association (NFPA) 780 (NFPA 1995).

In summary, the architecture and structural building appears well designed for human operations. Work areas are adequate and provide room for humans to accomplish their tasks. Safety considerations, particularly shielding, has been given much thought, which is reflected in the design. For example, extra thick concrete walls for the support area building adjacent to the CSB shelter area. These walls should not only provide for required shielding, but also reduce the exposure to noise from the MHM operation and other machinery.

\subsection{OPERATIONS OVERVIEW}

The HFE analyses of various human-machine interface, during CSB operation have been covered in SNF-3907. This supplemental report updates the analyses and provides information on those systems not reviewed by SNF-3907. An operational sequence block flow diagram overview is developed and is used for HFE/Erg analysis of the operations conducted in the CSB (See Appendix A, Operational Sequence Block Flow Diagram Overview, H-2-123400, sheets 1-7). The flow diagrams provide a complete depiction of currently known CSB cask-MCO processing activities, times to complete each process, required personnel involved, and equipment or machines used in the process.

Individual operations within the CSB are described in this section. The three major operations are baseline operations, passive cooling, and overpack storage tube purge operations. Baseline operations at the CSB include receiving operations, cask servicing operations, MCO operations, and MCO sampling operations. All operations in the baseline operations involve safe handling of sealed MCOs containing SNF.

An MCO, loaded with SNF, is shipped from the Cold Vacuum Drying Facility (CVDF) to the CSB trailer vestibule inside a transportation cask. The transportation cask is unloaded from the trailer, carried to the MCO service station pit, and preparations are made for cask servicing operations. The following sections describe the equipment and operations involved in receiving a cask and preparing for cask monitoring:

\subsubsection{Receiving Crane}

The receiving crane is designed to off-load an MCO transportation cask from a transportation trailer (see Figure 2-3, Cask Transportation System Arrangement) and transfer the 
cask to the MCO service station pit. The receiving crane and appurtenances off-load the MCO transportation cask from the transport semitrailer. After an MCO has been removed from the cask by the MHM, the receiving crane retrieves the cask, including an empty MCO, and places the cask back on the transport semitrailer. The major components used during the offloading of a transportation cask are:

- $\quad$ Receiving crane

- $\quad$ Cask lifting yoke

- Rail frog assemblies

- $\quad$ Service station impact absorber

- Cask transfer safety system.

The receiving crane positioning/interlock control system, the receiving crane lifting yoke, the service station impact absorber, the MHM rails and rail frogs, the $\mathrm{MCO}$, and the transportation cask are classified as safety class and important-to-safety Category $\mathrm{A}$. The receiving crane structure, the hoist, and the cask transfer safety system are classified as safety significant and important-to-safety Category B. The transportation cask shielding and the MCO shield plug shielding are classified as safety-significant.

The receiving crane is a 60-ton capacity gantry crane with one 60-ton main and one 10-ton auxiliary wire rope hoist supported on a top-running trolley. The crane operates in a clean indoor environment in the trailer vestibule and load-in/load-out areas of the CSB. The crane is equipped with a shielded operator station and remote accessories, such as a powered rotating hook, local control panels, and a radio-controlled operator station.

Activity and Tasking: A cask transported to the CSB enters the trailer vestibule area, on a trailer backed into the vestibule and stopped at the appropriate position. The trailer landing legs are lowered to unhitch the trailer, and the tractor then leaves the area followed by lowering of the telescoping door to seal the area. The cask support and tie-down system hold the cask in an upright position surrounded on all sides by a work platform. A stairway provides access for operations personnel to the elevated platform for cask inspection, radioactivity monitoring, loosening the cask tie-downs, and latching and unlatching the cask lifting attachment yoke and crane hook. (Note: the cask lifting yoke has two hooks fabricated from 2.25-in.-thick plates and welded to two triangular 1-in.-thick plates. The plates are connected at the top by a 4-in.diameter pin welded to the triangular plates.) The receiving crane main hook engages with the cask lifting yoke pin to lift the cask. The receiving crane has a hook coverage capability that extends beyond the CSB SNF requirements. The maximum hook elevation of $27 \mathrm{ft}$, for the main hoist, is needed to lift a transportation cask containing FFTF fuel from the road truck. This hook elevation is approximately $5 \mathrm{ft}$ higher than the SNF cask transportation requirements. The receiving crane has interlocks preventing simultaneous horizontal and vertical movement.

The cask transfer safety system (see Figure 2-4, Cask Transportation Safety System Arrangement, Depicting 60-Ton Crane Assembly) is designed to prevent floor impact of a 
potentially dropped MCO transportation cask during unloading operations in the CSB trailer vestibule area. The transportation cask, with an $\mathrm{MCO}$ inside, is removed from the transportation trailer by the receiving crane. The cask transport safety system utilizes one portable 8-in. high cask transport safety system impact absorber placed next to the transportation trailer and under the transportation cask as the transportation cask is lowered from the transportation trailer to just above floor level. The impact absorber is $4 \mathrm{ft}$ by $5 \mathrm{ft}$ and 6-in.-high and consists of a 1 -in.- thick carbon steel top plate, an 0.5 -in.-thick steel bottom plate with impact absorber material between the plates. The portable cask transfer safety system impact absorber has spring loaded retractable casters mounted to the sides of the bottom plate. The canisters will collapse when the weight of the platform is exceeded or impacted by the cask. Also, to prevent a dropped cask from falling on its side, two mechanical pivoting safety rails are mounted to the south legs of the receiving crane. The safety rails are raised and lowered by means of a hand operated cable winch with an auto brake that is locked into position during cask movement. The top bar of the safety rails is high enough above the cask center-of-gravity to prevent the cask from tilting and toppling over during a potential drop accident.

The portable cask transport safety system impact absorber, placed under a transportation cask, mitigates the consequences of the unlikely event of a transportation cask being accidentally dropped onto the floor. In the event the 60-ton receiving crane hoist fails during transportation cask unloading operations, the cask transport safety system impact absorber will absorb the impact of the transportation cask. The safety rails will prevent the cask from tipping over and the $\mathrm{MCO}$ will be protected from damage.

The receiving crane is expected to receive some radiation exposure when the transportation cask is being moved. However, based on the fact that the crane is unlikely to experience a 40-year continuous work schedule, the crane is expected to operate for the 40-year design life without significant deterioration from radiation exposure (based on calculated lifetime total integrated dose).

The receiving crane has a shielded operator station mounted on the north bridge truck. The shielding is 3.5-in.-thick carbon steel with a viewing window that has a shielding equivalency of $3.5 \mathrm{in}$. of iron or $1 \mathrm{MeV}$ photons reduced by a factor of 50 . Shielding calculations performed by the receiving crane vendor confirm that a shield thickness of 3.5 in. of steel results in an operator dose of $\leq 0.2 \mathrm{mrem} / \mathrm{h}$. In addition, the specification requirement that the $1 \mathrm{MeV}$ gamma photons be reduced by at least a factor of 50 is met by the lead glass shielding window when using a source based on the 270 Mark IV fuel elements. This source is more representative of the actual source to which the crane cab operator will be exposed. Dose measurements and shielding equivalency estimates will be performed during startup and routine operations.

The receiving crane, including its load blocks, will not be exposed to temperatures, pressures, or chemicals that would require special design considerations. The receiving crane design provides for fail-safe features.(e.g., load blocking and brakes) to be applied upon loss of power. Also, when an earthquake is detected, wall-mounted accelerometers in the northeast corner of the load-in/load-out area automatically disconnect the power source for the receiving crane (see Section 2.1.4 CSB Above-Grade Structures for an overview description of seismic power trip). 


\subsubsection{Mobile Service Station Pit and Tent}

The cask is prepared for servicing at the service station pit (see Appendix A, Operational Sequence Block Flow Diagram Overview, H-2-123400, sheets 2 and 3). The following major components are included in the process of preparing a cask for servicing:

- MCO service station pit

- Mobile service station tent

- Tent gantry hoist

- Shield hatch assembly.

The mobile service station tent, tent gantry hoist, and auxiliary equipment are designed for preparing the cask for servicing operations. After cask servicing operations it is also designed for safe handling of the transportation cask, lid, and for preparing the cask for removal of the MCO by the MHM (see Figure 2-5, Service Pit Operations).

The mobile service station tent provides for confinement of potentially radioactive particulate adhering to the outside of the MCO. The tent may not be needed if operational experience shows that the MCOs received from the CVDF are free of radioactive particulate. The mobile service station tent, if needed, is manually wheeled and travels on rails in the load-in/loadout area of the CSB. The tent is seismically stable. The tent is $26 \mathrm{ft}$ by $18 \mathrm{ft}$ by $8 \mathrm{ft} 6 \mathrm{in}$.- high) and is stationed adjacent to the east of the MCO service station. If needed, the tent is placed over the MCO service station pit after a transport cask loaded with an $\mathrm{MCO}$ is placed in the pit. The tent is manually moved away from the MCO service station pit after cask-MCO servicing operations and the shield hatch assembly has been placed over the pit. The 10-in.-thick carbon steel shield hatch assembly replaces the cask lid function of shielding the MCO during MCO removal by the MHM.

The mobile service station tent is equipped with a HEPA filtered exhaust unit with a builtin standby exhaust fan. The exhaust unit discharges into the operating area where the air combines with the building ventilation system and discharges to the exhaust stack. With a loss of normal power, the mobile service station tent exhaust system shuts down until power is restored.

The tent and the filtered exhaust system, when used, form the confinement envelope for the ventilation area around the MCO service station pit. The tent is equipped with a lighting system to provide an illumination level of not less than 70 foot-candles for a distance of $9 \mathrm{ft}$ from the top of the MCO. The operating conditions for the cask receiving system are (defined in HNF3553, Annex A, Chapter A2.0). The tent is large enough to house the cask lid, the shield hatch assembly, and the 5-ton tent gantry hoist. The tent is equipped with service sleeves, 3-in.diameter minimum, to bright services into the enclosure as needed to support ventilation, to supply power, and to introduce tools.

The 5-ton motorized tent gantry hoist (also provided with manual hoist raise and lower capability) is used to remove and replace the cask lid in the MCO service station pit after cask 
servicing operations are completed. After a power failure, the cask lid may be manually lowered to a safer position.

The mobile service station tent may undergo modification or possibly be eliminated from the design in the future. Mechanical handling devices for lifting the service station pit lid will still be needed, as manual handling of the heavy lid is not feasible.

\subsubsection{Cask Servicing (Multi-Canister Overpack Service Station Pit) and Operations}

The transportation cask servicing system is designed for checking the pressure of the transportation cask and, if necessary, taking a sample of the gases inside the cask and purging the gases from the cask. The cask servicing system is used by operators to check the pressure of the received cask in the MCO service station pit. Gases inside the cask are purged or vented with helium to ensure that potential hydrogen concentrations are diluted below flammable concentrations.

The following major components are part of the cask servicing operations:

- $\quad$ MCO servicing HEPA filter

- Flexible steel hose

- MCO servicing instruments.

An operator connects the MCO servicing system flexible steel hose to the cask access port on the cask lid. The servicing system pressure gauge indicates the internal pressure of the cask space surrounding the MCO. A cask pressure of less than $3.0 \mathrm{lb} / \mathrm{in}^{2}$ gauge indicates that the MCO can be handled using normal procedures. A pressure of $\geq 3.0 \mathrm{lb} / \mathrm{in}^{2}$ gauge indicates that the MCO seals may have released gases into the cask and is an "off normal" condition.

The normal operating steps include purging or venting gases from the cask through the MCO servicing system's HEPA filter and into the load-in/load-out area. These gases are mixed with helium to ensure that potential hydrogen concentrations that may be present are diluted to below flammable concentrations. The cask bolts are removed, the cask lid is removed and the shield hatch assembly is placed over the MCO service station opening using the tent gantry hoist. These steps prepare the MCO for lifting by the MHM (see Appendix A, Operational Sequence Block Flow Diagram Overview, H-2-123400, sheets 2 and 3).

If pressure in the cask is $\geq 3.0 \mathrm{lb} / \mathrm{in}^{2}$ gauge, the cask servicing system is designed for taking a sample of the gases, purging gas from the cask and replacing it with an inert gas. This allows the cask lid to be removed to prepare the suspect MCO for placement in an overpack tube for monitoring. The cask servicing system provides the primary safety function of preventing or mitigating radiological releases during cask purging. The primary safety objective of cask servicing activities involves safe handling of the hydrogen-containing atmosphere to prevent the atmosphere from becoming flammable or explosive. 


\subsubsection{Multi-Canister Overpack Handling Machine And Operations}

An overview of the MHM operation is shown in Appendix A, Operational Sequence Block Flow Diagram Overview, H-2-123400, sheets 1 and 7. The MHM is designed for safe handling of an MCO in the operations area of the CSB. This operation involves two operators, and one health physicist (for survey tasks). The MHM removes an MCO from the cask in the MCO servicing pit and carries it to a standard storage tube for interim storage, to the sampling/weld station for sampling/weld operations, or to an overpack storage tube. The MHM, containing the MCO retrieved from the MCO service station pit, moves on its gantry crane to a position above the storage tube. The seismic restraints are set. The MHM barrel is rotated until the storage tube plug cavity is above the storage tube plug. The MHM retractable shield skirt is lowered to meet the operating deck to form shielding, and the tube plug is raised into the tube plug cavity. Once the tube plug is fully raised, the MHM barrel rotates until the MCO cavity is aligned with the storage tube, and the MCO is lowered into the storage tube. When the MCO is at rest, the MHM grapple disengages and withdraws. The MHM barrel rotates to place the tube plug cavity over the storage tube, the tube plug is lowered into place, the turret is rotated to the camera position, the seismic restraints are released, and the MHM moves away. The storage tube cover is replaced and staging operations are complete. In addition, the MHM retrieves impact absorbers from the MHM maintenance pit and lowers them into the standard and overpack storage tubes before retrieving MCOs from the service station pit.

The following major components are used during MCO operation:

- MHM bridge and trolley

- MHM cask and turret assembly

- MHM retractable nose unit and shield skirt

- MHM ventilation and filtration system

- MHM power and compressed air supply.

A bottom impact absorber is placed in each standard and overpack storage tube before placement of the MCO. Also, before the MHM can insert an MCO into a tube or remove an MCO from a storage tube, the storage tube cover is removed and an interface guide ring is manually installed on the top flange of the storage tube. An HPT surveys the storage tube cover while it is being removed and surveys the top of the tube plug assembly.

The MHM is a fully shielded machine designed to safely transport an MCO within the CSB facility service and operating areas, including the MCO service station pit, the sampling/weld station pit, and the storage tubes. The MHM also removes and replaces storage tube plugs, the service station shield hatch plate, the sampling station shield plug, and impact absorbers.

The MHM comprises a bridge and trolley system and a shield cask and turret system (see Figure 2-6, Multi-Canister Overpack Handling Machine, and Figure 2-7, MHM Cask Turret Assembly). The MHM weighs approximately $990,000 \mathrm{lbs}$. and is $17 \mathrm{ft}$ high from the operating 
deck to the top of the trolley rails. The MFM turret and MCO hoist enclosure extend above this height. The MHM gantry bridge structure spans $126 \mathrm{ft}, 6 \mathrm{in}$. from rail center to rail center.

Multi-Canister Overpack Handling Machine Operation Overview. MHM operation is governed by a system of electrical interlocks. These interlocks provide permissives to the operator that allow the operator to perform MHM operations (for example, actuate drives, motors) based on signals from a large number of sensors and switches. The sensors and switches are designed to monitor and detect important MHM configuration and interface parameters. Safety-related interlocks have two physically separate and electrically independent channels, both of which must provide a permissive before the interlock is satisfied. Once all channels of an interlock have been satisfied, the operator can actuate or energize the allowed drives, as desired, using manual controls. The operator station has indicator lamps, displays, and alarms that inform the operator of the state of the MHM. The operator will input commands to actuate drives via push buttons, switches, and joysticks.

The MHM is designed to prevent MHM lateral displacement that would shear an MCO as it is being raised or lowered inside the throughport. A system of MHM drive control interlocks provides for safe operation of the MHM. Interlocks prevent inadvertent activation of both bridge drive motors and the trolley drive motor, unless the interlock sensors report that the state of the MHM is appropriate to allow safe operation for the motors. This interlock-permissive system greatly reduces the chance of or, in some cases, prevents damage to an $\mathrm{MCO}$ caused by operator error, normal paraffin hydrocarbon, or failed protection channels.

The MHM bridge and trolley system comprises a double-girder bridge with a top-running trolley supported on four end trucks that have two wheels each. The crane bridge rides on northsouth runway rails recessed in the operating deck. The $7.5 \mathrm{hp}$ bridge drive truck system on each south girder (two $7.5 \mathrm{hp}$ motors total) is geared down to a 244:1 ratio. Associated with each of the bridge trucks (four total) is braking from the flux vector-controlled pin, if the hoist is not at its top position. These pin drive systems have position switches that permit power to the MCO hoist only on redundant indication of full insertion.

A collision-avoidance system (refer to Figure 2-7, MHM Cask Turret Assembly, depicting collision-avoidance system) is provided to detect objects on the operating deck of the CSB that could interfere with the movement of the MHM and to stop the MHM if objects are detected. The MHM collision-avoidance system uses an octagonal arrangement of pressure-sensitive bumpers with redundant sensors surrounding the retractable shield skirt at the bottom to detect, by contact, objects that are in the path of the MHM. The MHM collision-avoidance system activates a signal to the MHM control system once the object is detected (bumped), and the P10 interlock prevents movement of the MHM toward the detected object. The P10 interlock inhibits crane bridge travel and prevents crane trolley travel collision with the sample station gantry crane, the service tent, or an object greater than 2 in. high standing on the operation deck.

The receiving crane and the MHM anticollision system prevents the MHM and the receiving crane from colliding when they operate at the north end of the CSB operating area. When one crane or the other is in the "overlap zone," where a collision could occur, a facility limit switch affixed to the facility wall is tripped (de-energized) or a limit switch on the MHM is 


\section{SNF-4831 REV 0}

activated by a facility striker to restrict the function of the other crane equipment so that it cannot travel into the same area. Plungers are actuated to trip redundant MHM limit switches, and thus crane power, if the MHM attempts to enter the north end of the CSB operating area when the receiving crane is in use. When tripped, the anticollision system stops northward MHM bridge travel. The P5 MHM interlock inhibits crane bridge travel into the "overlap zone" if the receiving crane is in the "overlap zone."

The integrated cask and turret system allows the MHM to: ,

1. Engage the receiving station, a storage tube, or the sampling/weld area

2. Remove the shield hatch plate, the tube plug, or the sampling/weld area center shield plate

3. Retrieve and transport an MCO from the transport cask

4. Place an MCO in, or remove and transport an MCO from, a tube or sampling/weld station

5. Replace the tube plug, shield hatch plate, or center shield plate

6. Transport an MCO to another designated station or return it to the MCO service station pit or sampling/weld station

7. Place an intermediate impact absorber in the storage tube.

The cask and turret system comprises a stack of interconnected components that is rigidly suspended from the trolley. The trolley supports a rotating upper turntable, which supports the upper turret and hoist assembly. A stationary lower turntable and retractable shield skirt are fixed below the rotating turret by the base torsion link arm from below the trolley. The two rotating points use large concentric slewing bearings and a large ring gear that are mounted concentrically. The upper turret and the turntable can spin freely around the vertical centerline established by the two bearings. Rotation of both components is controlled with operational interlocks and seismic restraints, especially during MCO raising and lowering operations.

The MHM festoon system provides electrical power and a compressed air supply for the MHM. Electrical power for the MHM is provided from the northeast corner of the CSB through a $480 \mathrm{~V}$ main disconnect switch that is fed by one of four motor control centers in the building. Power is routed to the MHM bridge and trolley by way of the bridge festoon and the trolley festoon. The disconnect switch controls all MHM power loads. Electrical service to the cask mechanisms is provided by way of the turret festoon and a flexible connection between the trolley and rotating upper turret.

The CSB compressed-air supply line provides plant air to the MHM festoon cable line

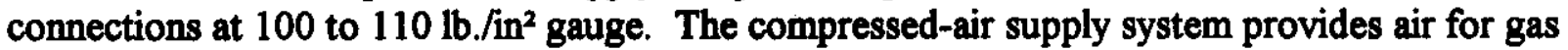
cylinder actuation (opening) of the MCO grapple and also for cooling the MCO camera lights. The cooling airflow is sized to keep the ambient air temperature around the camera to less than 60 
${ }^{\circ} \mathrm{C}\left(108^{\circ} \mathrm{F}\right)$ while cooling the lights provided for the cameras. An onboard air receiver is required to function as a backup compressed-air source to the manually actuated MCO grapple opening valve. This arrangement ensures that the manual opening function is always available.

Multi-Canister Overpack Handling Machine System Operation Overview. The MHM retrieves an MCO after the transportation cask, containing the MCO, has been lowered into the MCO service station pit by the receiving crane. The sides of the MCO service station pit are equipped with guides to align the cask so the MCO can be removed from the cask by the MHM's MCO grapple and hoist (see Figure 2-8, MCO Hoist Assembly). An impact absorber at the bottom of the pit supports the cask at the correct elevation so the grapple and hoist will encounter the MCO at an accessible height. The cask impact absorber also mitigates any damage to an MCO caused by a cask drop.

The MHM may remove an MCO from the service station pit and transfer the MCO to (1) a storage tube; (2) the sampling/weld station, or (3) an overpack storage tube assembly provided in Vault 1 for storing and monitoring suspect MCOs (see Appendix A, Operational Sequence Block Flow Diagram Overview, H-2-123400, sheet 1). Similar operations take place for removing hatch lids, removing plugs, inserting the MCOs, plugging, and reinstallation of hatch lids. Control panels, CCTV, instrument panels, and waming devices all provide the operator indications of MHM operations and control over the MHM system. Interlocking devices (explained earlier in this section) serve to reduce the occurrence of human error.

The sampling/weld stations, located in pits at the south end of the CSB, are used to weld the steel closure caps on the MCOs. The sampling/weld station located in the easternmost pit (pit 7) will serve initially as a sampling station for monitoring of MCOs. The sampling/weld station pit and trench shields are designed for docking with the MHM when the MCO transfers are made between the MHM and the sampling/weld stations. The operator positions the MHM over the sampling/weld station pits and centers precisely over the shield assembly for MCO transfer operations. Precise alignment with the shielding assembly is accomplished by using the MHM television camera (CCTV) and locating the target on the center shield plate pintle. The center shield plate pintle is designed to be handled by the MHM plug grapple (see Figure 2-9, Tube Plug Grapple). The center shield plate is stowed in the plug cavity of the MHM during MCO lowering and raising operations. All equipment that may be placed in the coverage area of the MHM, including the sampling/weld station gantry crane and hoist, is less than $8 \mathrm{ft}, 10 \mathrm{in}$.-high to avoid interference with the MHM bridge.

MCO transfer at the sampling/weld station is accomplished after lowering the MHM nose unit onto the welding/shielding station shielding assembly and the shielding skirt against the deck around the sampling/weld station pits. The MCO grapple and hoist raise or lower the MCO, which is subject to restrictions by the MHM interlocks.

The MHM shielding design objective is based on 10 CFR 835, "Occupational Radiation Protection," for controlling personnel exposure from external sources of radiation in areas of continuous occupational occupancy $(2,000 \mathrm{~h} / \mathrm{yr})$. The design objective is to maintain exposure levels below an average of $0.5 \mathrm{mrem} / \mathrm{h}$, and as far below this average as is reasonably achievable. 


\section{SNF-4831 REV 0}

Maintenance Overview. The MHM moves to the maintenance pit, where the maintenance pit equipment frame is located, which supports the retractable shield skirt and retractable nose for maintenance. The MHM is positioned over the MHM maintenance pit equipment frame and aligned with the assistance of a spotter in the pit providing direction to the MHM operator. The maintenance pit equipment frame has the necessary interface components to remove the MHM retractable nose assembly. The MHM maintenance trolley sets on the concrete operations deck during assembly and maintenance disassembly operations. The maintenance trolley enables disassembly of the MHM and provides tooling and fixtures for major repairs. The MHM maintenance trolley is a rigid structure with dual casters in each corner. It is rolled into position over the maintenance pit and centered on the maintenance pit equipment frame. As components are removed, the maintenance trolley supports and maintains stability for the equipment above. Additional frames and structures are provided with the MHM maintenance trolley to perform different tasks as appropriate.

Multi-Canister Overpack Handling Machine Safety Considerations. The interface guide ring, the MHM seismic restraints, and some of the MHM interlocks (for example, interlocks that prevent; translational shear, turret rotation when the MCO hoist is not fully raised, and rotating the turret to the MCO position when over the maintenance pit. MHM seismic detection and power-disconnect system, and MHM interlocks that ensure the MHM turret is rotated to the navigate position before allowing power to the bridge or trolley drive motor.) are classified as safety class and important-to-safety Category A. The collision-avoidance system (interlock P10), the MHM radiation protection interlock system, and the MHM fixed shielding are safety significant. The MHM structure and the MCO hoist are safety significant and important-to-safety Category B. The remaining components of the MHM and the anticollision system are classified general service.

\subsubsection{Multi-Canister Overpack Sampling/Weld Operations}

The MCO sampling system is used for withdrawing a sample of gases from the monitored MCOs according to a predetermined schedule. Weld equipment will provide additional sealing of the MCO by welding a cap on the MCO. The MCOs are sampled periodically at a sampling/weld station (see Figure 2-11, Sampling/Weld Station Gantry Crane, Floor Plan and Figure 2-12, MCO in Sampling/Weld Pit, Section). The sampling procedure provides a process for monitoring MCO storage of SNF at the CSB.

The major components of the MCO sampling operations are as follows:

- Sampling/weld pit impact absorber

- Sampling/weld gantry crane and hoists

- Sample cart

- Sample hood

- Sampling pit cover plate 


\section{SNF-4831 REV 0}

- Sampling/weld station chiller and cooling cap

- Sampling/weld station HEPA filter and exhauster

- Sampling temporary shield plate assembly.

The sampling process begins when the MHM lowers a monitored MCO into the sampling/weld pit. The temporary shields are used whenever a monitored MCO is raised or lowered into the sampling station to reduce the radiological streaming coming from the MCO to within as low as reasonably achievable (ALARA) limits. An MCO placed in the sampling /weld pit is supported by the rotating shield that rotates on bearings retained in the stationary shielding. The stationary shielding is supported from the pit floor using 5 -in. diameter pipes. The fixed optical pyrometer senses and measures, and the Distributed Control System (DCS) records, the MCO profile skin temperatures as the MCO is lowered into the sampling station. An impact absorber in the bottom of the sampling station cushions the MCO if it is dropped and prevents rupture of the MCO. The DCS skin temperature data can be used to indicate possible heatup problems from the SNF in the MCO. After placing the MCO in the pit, a hand-held optical pyrometer is used to measure the MCO cover surface temperature. An MCO cover surface temperature exceeding a predetermined range will require cooling of the cover before sampling operations begin protecting the operator from skin burns. A chilled cooling cap will be placed on the $\mathrm{MCO}$ cover to cool the top surface to a safe temperature range (typically $<49^{\circ} \mathrm{C}\left[<120^{\circ} \mathrm{F}\right]$ ).

The MCO temperature and pressure are recorded and gases in the MCO are sampled using the MCO sampling cart. After monitoring and sampling operations are complete, the MCO pressure is reestablished with inert gas. The MCO mechanical seal and cover plate may be leak tested to confirm seal integrity. These monitored MCOs will eventually be transferred to a weld station for the cover cap welding operation. If required, the sampling station chilled cooling cap is connected to the chilled supply and return lines to cool the MCO cover. The stationary shielding and cooling cap are designed to cool the MCO by removing heat from the MCO body and top.

The trench cover is removed and stored, and guard rails are installed to prevent workers from falling into the open trench and the sampling station pit. A ventilation supply system has not been provided for the sampling/weld trenches, because the trenches are too shallow to be considered as a confined space. If the MHM inadvertently moves near the sampling/weld gantry crane, the bumpers attached to the sampling/weld gantry crane will activate the MHM collisionavoidance system to prevent a collision of the MHM with the sampling/weld station sample hood. A 1-ton crane hoist is used to lower the sampling hood over the sampling pit. The sampling hood is used to confine potential airborne contamination coming from an accidental MCO release during sampling operations and dilute any hydrogen released.

The sampling cart is moved near to the sampling pit and connections are made to the utilities in the sampling/weld pit. The quick-disconnect lines from the sampling cart are attached to the inert gas supply, the sampling hood filter, and the discharge line of the sampling hood. The sampling hood flexible exhaust line is connected to the sampling station HEPA filter and exhauster. The cart is readied for operation. An operator uses the MCO process valve operator 
to open the MCO process valve and start the sampling. The sampling hood and the HEPA filter (FH-9) provide a confinement barrier preventing the release of particulate contamination to the operating area environment. After sampling operations, the sample cart pipelines are vented and purged.

The sampling/weld station HEPA filtered exhauster is shut down, the sampling cart lines are disconnected, and the sample hood flexible line to the HEPA filter and exhauster is removed. The sample hood can now be lifted off of the sampling/weld station pit using one of the 0.75 -ton hoists. The guard rails are removed and the trench cover is reinstalled. The sampling/weld station chiller is shut down. The MHM then removes the monitored MCO from the sampling/weld station and places it in the assigned preselected storage tube. The sampling pit cover plate is placed over the sampling/weld pit, if no other monitored MCOs are to be place in the sampling/weld pit.

Cap Welding Operations. The design of this equipment is being finalized and will include all equipment necessary for welding caps onto the MCOs (i.e., welder, weld station chiller, ventilation of weld gases and utility connections).

\subsubsection{Tube Vent and Purge Cart}

The tube vent and purge cart (see Figure 2-13, Tube Vent and Purge Cart Assembly) include features to analyze gas from the overpack storage tube, purge generated gas (containing hydrogen) from the tube through a HEPA filter to the operating area atmosphere, and replace the purged gas with an inert gas (e.g., helium). The cart contains an inert gas supply (two gas cylinders); a flexible steel hose fitted for the overpack tube; a flexible steel hose for the standard storage tubes; a CAM unit; a radioactive gas monitor; a hydrogen gas monitor with associated alarms; a sampling connection; a HEPA filter; a gas monitor port heat exchanger; and an oxygen concentration monitor with associated alarms. The tube vent and purge cart interfaces with the overpack tube plug connector, the floor electrical supply, the standard tube plug connector, and the helium filling station. The tube vent and purge cart also have the capability to sample standard storage tubes.

The tube vent and purge cart is a battery-powered, rechargeable, utility vehicle. The battery is maintenance free and attached to the cart inside a battery compartment designed to contain any acid that might leak from the battery. This battery design and configuration minimizes loss of battery acid and subsequent hydrogen generation caused by acid reaction with exposed metal components. The cart is designed with a rear bed and tow hitch. The rear bed, or cargo deck, is sized for a platform $4 \mathrm{ft}, 7 \mathrm{in}$. by $9 \mathrm{ft}, 7.5 \mathrm{in}$. The bed is fitted with all of the equipment and systems required to perform the tube venting and purging operations. A flexible steel hose connects the cart's piping header with the tube plug quick-disconnect coupling. The tube vent and purge cart's rated load capacity is specified to be not less than $3,000 \mathrm{lb}$. The cart can tow a portable floor crane. The floor crane is used for lifting the $425-\mathrm{lb}$. center hatch of the standard or Qverpack tube plug cover. The portable floor crane is used to remove standard or overpack tube plug covers in preparation for tube plug removal by the MHM. The standard tube plug cover weighs $1,475 \mathrm{lb}$., and the overpack tube plug cover weighs $1,805 \mathrm{lbs}$. The portable crane's rated capacity is specified to be $2,000 \mathrm{lbs}$. The cart receives electrical power for 


\section{SNF-4831 REV 0}

recharging its batteries and operating equipment by means of an on-board retractable cable reel ( $480 \mathrm{~V}, 3$-phase, 4-wire cord with ground). The cord is plugged into the electrical distribution system outlets recessed into the operating deck.

During the time the cart is being used to perform venting and purging, the portion of the connected system that is between the cart-mounted HEPA filter and the tube atmosphere serves the same secondary confinement role as the overpack storage tubes. Under accident conditions, this confinement provides mitigation of radionuclide releases from the tubes. During purging operations, the purge cart is secured in place by wheel chocks adjacent to the storage tube being serviced. The portable crane is used to remove the center hatch and move it to a temporary location convenient to the tube. Removing the quick-disconnect cap on the MCO overpack tube plug, connecting the flexible steel hose from the cart to the plug, and opening the pressureindicating valve on the cart shows the tube pressure. This pressure can be compared with the pressure indicated by the tube plug local pressure gauge. If these two pressure gauges differ by more than $0.5 \mathrm{lb} / \mathrm{in}^{2}$ gauge, both instruments are recalibrated before continuing the purging operation.

The purge cart CAM, hydrogen monitor, and radioactive gas monitoring systems measure radioactivity, hydrogen concentration, and radioactive gas concentrations of gases being evacuated or purged from the tube. Gas flow rate to the monitoring equipment is monitored. If the flow rate to the CAM and radioactive gas monitor drops below the setpoint value, or if the flow to the hydrogen monitor drops below the setpoint value, a low-flow alarm activates alerting the operator that the gas monitoring equipment may not be operating properly. The hydrogen monitor alarms if the hydrogen gas concentration exceeds $1 \%$ by volume. The gas temperature is measured and an alarm is activated if the temperature exceeds $52{ }^{\circ} \mathrm{C}\left(125^{\circ} \mathrm{F}\right)$. A high gas temperature could cause thermal damage to the gas monitoring equipment. An in-line gas cooler has been designed to cool gases before they reach the CAM and gas monitors to prevent thermal damage to the gas monitoring equipment.

MCO overpack tube gases are vented through a HEPA filter to remove radioactive contamination before the gases pass into the operating area atmosphere. If there is a breach or leak in the MCO, spent fuel particulate may be suspended in the overpack tube atmosphere. An HPT will provide periodic radiation monitoring of the FH-3 HEPA filter and determine when filter changeout is needed. A radiation detection system with an alarm setpoint is not practical for the HEPA filter.

After venting and purging the overpack tube, the flexible connection to the tube plug is disconnected, the quick-disconnect cap is replaced, the tube plug center hatch is replaced using the hoist, the cart is disconnected from the electrical outlet, and the cart is returned to the cart storage area. In the cart storage area, cart preparation activities for future storage tube purging or venting operations include recharging the cart battery, refilling the inert gas bottles, calibrating instruments (if needed) and general cart maintenance.

The tube vent and purge cart specification call out the following human factors performance criteria: 


\section{SNF-4831 REV 0}

- The tube vent and purge cart shall incorporate human factors engineering in the design and layout of equipment. Controls and all components that require maintenance or frequent access shall be arranged in a safe and efficient manner. Controls shall be logical and convenient and meet the requirements of Specification Section 17861B or 17861C, Local Control Panels.

- The design of the system shall be conducive to the performance of maintenance activities, and shall reduce maintenance requirements where possible. Cabinet and panel doors shall be designed to swing to a secured position, permitting full access when open, without obstructing or creating a work hazard. Maintenance schedules and requirements shall be submitted for Buyer review.

- The vacuum pump shall be provided with a sound enclosure that will limit the sound level of the operating vacuum pump to $70 \mathrm{~dB}$ at a distance of 3 feet. The enclosure will not obscure the operator's view of controls, gauges and other instrumentation or impede normal operating procedures. It shall be removable, providing for easy access for maintenance activities. It shall be ventilated if required to prevent excessive heat accumulation in accordance with the pump manufacturer's recommendation.

- At location where the operators are required to step up onto the cart equipment platform in performance of normal operations, the cart shall be equipped with a fold down step and hand holds for operator accessibility.

- To the extent possible, quarter-turn valves shall not be located where they can be inadvertently bumped and actuated. If valves must be installed in an exposed location where they may be at risk, they shall be protected with handle guards. Valves which must be reached from the floor shall require no more than a 2-foot, 6-inch reach.

Vendor submittals include HFE requirements. Therefore, it is expected that the cart will adequately incorporate HFE criteria. The HFE requirements will be checked during engineering acceptance testing of the equipment.

\subsubsection{Heating, Ventilation, and Air Conditioning System}

According to the SNF CSB HVAC System Design Description (HVAC SDD), the HVAC system is designed to provide, along with physical barriers, part of the CSB contamination confinement system and contamination control within the CSB. The HVAC system provides a controlled pressure gradient flow of air from outside the CSB inward through uncontaminated. areas to potentially contaminated areas of the building and out through HEPA filters and a monitored exhaust. The HVAC system also provides climate control to ensure that environmental conditions in the CSB are maintained in the required ranges for personnel and equipment. The HEPA-filtered service station enclosure discharges air into the operations area. The operations area air exchange rate is approximately 1.5 volume changes per hour.

The HVAC composite flow diagram is available in CSB FSAR Chapter A2.0 (Figure A2-47). The HVAC system has its own programmable controller. The HVAC system is 
manually adjusted to achieve the operating area negative pressure. Dampers automatically compensate for changes in filter pressure drops or other sources of exhaust from the CSB. The setpoint for starting the second exhaust fan, in the event of failure of the lead fan, is $50 \%$ of 4,500 $\mathrm{ft}^{3} / \mathrm{min}$. The HVAC system comprises two subsystems, the operating area HVAC subsystem and the support area HVAC subsystem.

Operating Area Heating Ventilation and Air Conditioning. The operating area HVAC subsystem provides ventilation and air conditioning for the CSB operating area and the HVAC equipment room. The operating area HVAC system is designed to maintain a negative pressure of $0.10 \mathrm{in}$. with regard to the outside environment to ensure airflow from areas of lower contamination potential to areas of higher contamination potential. The operating area HVAC system provides approximately $44,000 \mathrm{ft}^{3} / \mathrm{min}$ of supply air and recalculates approximately 35,500 $\mathrm{ft}^{3} / \mathrm{min}$ of air through the operating area and HVAC equipment rooms.

During cold weather conditions, electric heating elements (present in the electric duct heater and in each operating area HVAC air handling unit) operate in a controlled, cascading fashion to maintain the operating area air temperature within the normal range above the lowtemperature setpoint. For warm weather conditions, external, air-cooled condenser/compressor units that supply refrigerant to cooling vanes in the air handlers maintain the operating area air temperature in the normal range below the high-temperature setpoint.

Support Area Heating Ventilation and Air Conditioning. After passing through the operating area or the HVAC equipment room, air is exhausted from the support area HVAC through HEPA filters, through an exhaust fan, and out the main exhaust stack where continuous radiation monitoring records contamination, if any, in the air. Heater blankets in each exhaust HEPA filter housing prevent the accumulation of condensation on the filters. Ember screens upstream of the HEPA filters protect the filters from potential fire damage and meet the requirements of the DOE Filter Plenum Fire Protection Standard (DOE 1993).

The operating area HVAC airflow is balanced by setting manual airflow dampers in the operating area intake, recirculation, and HVAC equipment room ducts to achieve the desired differential pressure with a constant exhaust fan airflow. Manual damper MVD-1 maintains the balance of intake air to recirculating airflow for the operating area HVAC subsystem. Manual damper MVD-2 maintains the balance of flows exiting the HVAC equipment room between that entering the exhaust flowpath and that recirculating to the operating area HVAC subsystem. Manual damper MVD-3 sets the airflow entering the HVAC equipment room. Manual damper MVD-4 maintains the airflow to the "entry-related" rooms of the support area HVAC subsystem. The operating area HVAC controls the positions of the inlet vane damper of the operating area exhaust fan, varying the overall HVAC exhaust to maintain the desired constant exhaust fan discharge airflow. If both exhaust fans are shut down, the operating area HVAC air handlers shut down automatically (loss-of-flow controller FIC-281 50\% exhaust flow permissive). If the operating exhaust fan is shut down, the other ("lag") exhaust fan automatically starts, followed by a restart of the air handlers when the $50 \%$ exhaust flow permissive is again met on loss-of-flow controller FIC-281. By shutting down the air handling units and allowing only an exhaust fan to operate in a low exhaust flow condition, an over pressurization of the operating area HVAC system and possible contamination spread is averted. 


\section{SNF-4831 REV 0}

Automatic, fusible-link fire dampers and duct-mounted smoke detectors provide for worker safety and help prevent the fire from spreading to other areas of the facility. Operation of fire dampers in the operating area HVAC causes a loss of exhaust flow, with subsequent trip of the air handlers from the $50 \%$ exhaust flow permissive setpoint. The smoke detectors are mounted in the operating area HVAC return line and in the support area HVAC recirculation line. A trip of the operating area HVAC duct-mounted smoke detector shuts down the HVAC inlet air handlers; sounds an alarm within the facility; and transmits a fire alarm by radio from the fire control panel to the central fire alarm system, causing the fire department to respond. An exhaust fan continues to operate and maintains a negative pressure in the CSB. A trip of the support area HVAC duct-mounted smoke detector also performs these actions and sends a signal to the fire department. The fusible-link sprinklers in the support area release a water spray into the support area rooms when the air temperature melts the fusible link. Water flowing through the wet-pipe sprinkler system activates a flow switch in the sprinkler system and transmits signal to the fire department indicating that the sprinklers have activated.

The support area HVAC subsystem uses forced-air ventilation to maintain desired support area temperatures and required contamination confinement for potentially contaminated rooms in . the support area. The support area subsystem serves the control room, corridor, telephone and equipment room, effluent monitor room, generator rooms, electrical equipment room, regulated change room, HPT office, step-off pad and bag room, and the monitoring and decontamination room. Air is drawn from outside the building through roof-mounted intakes and an electric duct heater to an air handling unit and passes through the support area rooms. Air from entry-related rooms is exhausted through a prefilter and another air handling unit at a constant $920 \mathrm{ft}^{3} / \mathrm{min}$ (nominal) flowrate and is discharged to the HVAC equipment room (where it joins the operating area HVAC exhaust flow). Air supplied to the generator rooms is vented directly to atmosphere. The rest of the air is recirculated.

The support area HVAC subsystem airflow is balanced by setting the manual airflow damper in the duct to the entry-related rooms. The relief damper (which relieves excess air pressure from the support area to the outside) is set to achieve the desired negative differential pressure balanced with the rest of the support area HVAC subsystem in the entry-related rooms. The desired airflow throughout the rest of the support area HVAC subsystem is balanced with a constant exhaust airflow (to the operating area HVAC subsystem). The support area HVAC maintains the desired differential pressures and flows by controlling the speed of the exhaust fan to maintain a constant discharge airflow. Support area HVAC air handler AH-003 will not start until support area HVAC exhaust fan AH-004 flow rate reaches a minimum 50\% airflow. If exhaust fan AH-004 is shut down and low flow is sensed, the low-flow interlock automatically shuts down support area HVAC supply air handler AH-003 to prevent over pressurization. If the supply air handler is shut down, the exhaust fan continues to operate at a constant exhaust flow.

The HVAC system interfaces with the following system:

- The normal electrical distribution system provides electrical power for HVAC equipment operation; 


\section{SNF-4831 REV 0}

- The instrument/service air system (ISA) provides dry, oil and particulate-free compressed air regulated to $20 \mathrm{lb} / \mathrm{in}^{2}$ gauge for $\mathrm{HVAC}$ equipment requiring compressed air for operation (pneumatic actuators, dampers, instruments, etc.);

- Smoke detectors within the return duct of CSB-AH-001, CSB-AH-002, and CSB-AH-003 provide smoke detection for the HVAC Systems;

- The liquid waste collection system receives condensate from CSB-AH-001, CSBAH-002, and CSB-AH-003 cooling coils; and

- The support area subsystem (SHVAC) interfaces with the operating area HVAC (OHVAC) in the HVAC equipment room; part of the support area air is exhausted through air handling unit CSB-AH-004 into the HVAC equipment room, where it joins the OHVAC airstream.

The electric duct heaters of the OHVAC and SHVAC subsystems are located on the inlet ducts for those systems, in the HVAC equipment room. Air handling units of the OHVAC and SHVAC subsystems are located in the HVAC equipment room. Ductwork for the HVAC system extends throughout the operating area. Air-cooled condensing units serving the air handling units of the OHVAC and SHVAC heat pump unit are located outside, on the north side of the building. Exhaust HEPA filters, for the OHVAC subsystem, are located in the filter room, within the HVAC equipment room. Exhaust fans for the OHVAC subsystem are located in the HVAC equipment room.

The OHVAC operational requirements are as follows:

- Operating area temperature for normal operations is 16 to $29^{\circ} \mathrm{C}\left(60\right.$ to $85^{\circ} \mathrm{F}$ )

- $\quad$ HVAC equipment room temperature, normal operations is 13 to $35^{\circ} \mathrm{C}\left(55\right.$ to $\left.95^{\circ} \mathrm{F}\right)$

- Operating area operating pressure is -0.10 in.wg

- $\quad$ Filter room operating pressure is -0.10 in.wg.

Maintenance and surveillance requirements for the OHVAC include the following:

- Air handlers CSB-AH-001 \& -002 filters will be routinely changed

- Exhaust HEPA filters CSB-PF-001 \& -002 will be routinely changed

- HVAC pressure indicators will be periodically calibrated

- HVAC temperature indicators will be periodically calibrated

- OHVAC pressure indicators will be periodically tested

- OHVAC pressure indicators will be periodically calibrated 


\section{SNF-4831 REV 0}

- HVAC exhaust stack flow instrumentation will be periodically tested and calibrated

- OHVAC duct heater CSB-EH-002 will be periodically inspected

- Condensing units CSB-CU-001 \& -002 will be periodically inspected and cleaned

- OHVAC components and conditions will undergo periodic surveillance.

The SHVAC operational requirements are as follows:

- Support area temperature 22 to $26^{\circ} \mathrm{C}\left(72\right.$ to $\left.78^{\circ} \mathrm{F}\right)$

- Entry-related rooms operating pressure $-0.03 \mathrm{in} . / \mathrm{wg}$.

Maintenance and surveillance requirements for the SHVAC include the following:

- Air handlers CSB-AH-003 \& -004 filters will be routinely changed.

- Condensing unit CSB-CU-003 will be periodically inspected and cleaned.

- SHVAC components and conditions will undergo periodic surveillance.

HVAC Safety. Engineering is aware of hazards of the HVAC system including rotating equipment hazards from operating fans, electrical shock hazards from fan motors, and contamination hazards from airflows through potentially contaminated areas. Failure of either HVAC subsystem will create potentially harmful working conditions for personnel who must work in the CSB. These conditions include excessively hot or cold temperatures (depending on time of year and work locations) and slightly increased exposures to radioactive gases (which could be a safety issue if enough leaking MCOs are present).

\subsubsection{Health Protection System}

The health protection system is designed to monitor and warn CSB personnel of hazardous radioactive conditions that may occur as a result of malfunctions or accidents. It provides contamination control and limited computer-activated database management and status reporting. The health protection system employs radiation monitoring equipment and personnel contamination monitors.

The individual components of the health physics system are located throughout the CSB. Each instrument of the system has the ability to operate independently from the DCS. Not all of the health physics instruments are connected to the DCS. The data path provided from the instruments to the DCS enable data collected by the instruments to be stored, compared, and displayed in one central location. Portable decontamination showers are provided for facility personnel. 


\section{SNF-4831 REV 0}

\subsubsection{Lighting Systems (Illumination)}

Lighting systems for the CSB comply with Illuminating Engineering Society (IES) Lighting Handbook-1987 and ASHRAE 90-75R, Energy Conservation in New Building Design. The lighting systems include exterior, interior, standby, and emergency lighting. Exterior lighting illuminates the outside of the buildings using wall-mounted low-pressure sodium light fixtures and are controlled by light sensitive photocells. Interior lighting consists of normal lighting and standby lighting. Illumination levels follow DOE Order 6430.1A, General Design Criteria, which recommends $\mathbf{5 0}$ foot-candles for workstation lighting, 30 for work area lighting, and 10 for nonwork areas. Fluorescent light fixtures with energy saving ballasts are used in the support building rooms. High intensity discharge lighting fixtures are used in the operating area shelter. Standby lighting systems are controlled using manual light switches. Emergency lighting consists of individual lighting fixtures powered by an integral battery and self-luminous exit. The emergency lighting fixtures are installed in areas essential to life safety, ingress and egress routes from the equipment areas. Portable lighting may be needed during inspection of the cask surface to meet the requirements of ANSI 57.2, Design Requirements for Light Water Reactor Spent Fuel Storage Facilities at Nuclear Power Plants, which calls out 100 foot-candles for inspection at the surface of the cask.

\subsubsection{Distributed Control System}

The DCS is classified as general service, for safety consideration. The DCS provides monitoring capabilities for systems that provide confinement of incidental radioactive contamination to the CSB operating area by supporting key equipment connected to health physics monitoring systems, the HVAC system, the MCO servicing system, and the vault cooling system. The only control associated with the DCS is the MCO vent inert gas dilution control valve in the cask servicing system. All other functions of the DCS are monitoring functions of safety-significant equipment.

Components in the field (e.g., instruments, actuators, and sensors) are connected to the DCS through two remote termination unit cabinets that are located in rooms 019 and 030 in the facility. A data highway links all components of the DCS together. A color printer in the control room permits printing of hardcopy listings of alarms, control actions, and other reports by operator request. An audible alarm in the control room alerts the operators when set points are exceeded. The DCS is shown on Figure 2-14, Distributed Control System

Distributed control system instrument interfacing is with the following system:

- Health physics stack monitoring

- Health physics operating area

- Air compressor

- $\quad$ Air dryer 


\section{SNF-4831 REV 0}

- HVAC pump

- Uninterruptable power supply (UPS)

- Vault intake flow

- Vault inlet temperature

- Vault outlet temperature

- $\quad$ MCO servicing

- $\quad$ MCO sampling station.

Two operator work stations provide monitoring of components connected to the DCS, control functions, and the means for archiving mass data for safe storage. A programmable logic controller accepts sensor inputs from field devices and control inputs from the work stations. It processes these inputs through "ladder logic" algorithms in the programmable logic controller processor, then generates and transmits control signals to field devices such as controllers or alarms, and returns to the DCS for data recording or alarm annunciation. Programmable logic controller remote input/output units concentrate and transmit data to another data processing unit, which then acts as controller for the data processing unit represented by the Input/Output unit. The DCS receives electrical power from the normal electrical distribution system through battery-backed UPS DA-33-213.

The DCS has a "hot spot data" display screen designed for using operator input values (e.g., vault total heat, maximum MCO heat, and maximum storage tube heat) and CSB instrument data (e.g., vault inlet air temperature, vault outlet air temperature, and the passive ventilation system air flow rate) to estimate the maximum tube surface temperature and the maximum MCO surface temperature. These maximum temperature estimates use a computer algorithm based on data provided by the computer codes used for the passive ventilation heat transfer evaluation.

\subsubsection{Instrument/Service Air System}

The CSB System Design Description describes the function of the instrument/service air system. The ISAis designed to provide dry, oil- and particulate-free compressed air to components and locations throughout the SNF CSB. The ISAconsists of the compressed air system, which supplies the instrument air and service air subsystems.

The compressed air system supplies compressed air at 100 to $125 \mathrm{lb} / \mathrm{in}^{2}$ gauge for the two subsystems on a demand basis, and does not directly supply any end use. The instrument air subsystem distributes compressed air at 0 to $20 \mathrm{lb} / \mathrm{in}^{2}$ gauge to HVAC and other equipment (e.g., pneumatic actuators, control valves, dampers, instruments) throughout the SNF CSB, and to the MCO service station area. The service air subsystem distributes compressed air at 100 to $110 \mathrm{lb} / \mathrm{in}^{2}$ gauge to the MHM festoon, the sampling/weld station, and for general use (e.g., air tools) to utility stations in the north end of the CSB, near the receiving area. 


\section{SNF-4831 REV 0}

Operation of the ISAis described in the SDD.

Maintenance and surveillance requirements include the following:

- Compressed air subsystem pressure indicators will be periodically calibrated.

- Compress air subsystem temperature indicators will be periodically calibrated.

- Air dryer moisture indicator MSH-239 will be calibrated yearly.

- Air compressor inlet filter vacuum must be checked weekly, and the inlet filters replaced at least every six months or sooner, based on weekly checks.

- Air compressor oil and oil filter must be changed after the first week (150 hours) of operation, and once per year ( 8,000 hours) thereafter.

- Air compressor drive motor lubrication must be performed every three months, and Air compressor fan motor lubrication must be performed once per year.

- Air dryer dew point monitor must be checked and calibrated yearly.

- Air dryer solenoid and butterfly valve diaphragms and seats must be replaced yearly.

- Air dryer prefilter F-5 and afterfilter F-6 elements must be replaced yearly.

- Air compressor condensate strainers must be inspected once per year.

- The dryer prefilter drain valve and dryer system monitor lights (on the compu-purge controller panel) must be checked daily.

- Dryer exhaust mufflers, dryer filter $\Delta \mathrm{P}$ indicators, and dryer purge exhaust valves must be checked weekly.

- Dryer desiccant must be inspected yearly for oil contamination and broken desiccant.

- Air receiver VX-1 is an ASME pressure vessel that must be inspected yearly. A bypass line is provided so the vessel may be opened for inspection without interruption of compressed air system operation.

- Safety (relief) valves PSV-246 (mounted on dryer inlet shuttle valve CA-V-11) and PSV-249 (mounted on air receiver VX-1) must be tested and inspected every two years.

Maintenance requirements for the instrument air system and service air are:

- Instrument air subsystem pressure indicators PI-250 and PI-287 will be periodically calibrated. 


\section{SNF-4831 REV 0}

- Instrument air subsystem pressure control valves PCV-250 and PCV-261 will be periodically calibrated.

- Service air subsystem pressure indicators will be periodically calibrated.

- Service air subsystem pressure control valve PCV-256 on the service air branch line must be tested yearly to verify that the service air subsystem is shut off when the compressed air header pressure drops to $100 \mathrm{lb} / \mathrm{in}^{2}$ gauge.

- Service air subsystem pressure control valves PCV-252 and PCV-256 will be periodically tested.

Hazards of the ISAinclude rotating and remote-start equipment, high noise levels from venting air, and possible high temperatures at some points in the system. Proper precautions that should be taken include the use of personal protective equipment appropriate to the hazard expected.

\subsubsection{Gaseous Efnuent Monitoring System}

The gaseous effluent monitoring system (GEMS; formerly referred to as the continuous air monitoring system) is a microprocessor based particulate and iodine monitor and particulate/iodine collector mounted in a two component, open frame skid and cabinet assembly. The primary purpose of the system is to collect particulate and iodine effluent on fixed sample media for later laboratory analysis and documentation of emissions. GEMS is also designed to monitor real time alpha/beta particulate and iodine-129 gamma radiation effluent in a ventilation exhaust stack and provide early warning of out-of-ordinary emissions to CSB personnel. Visual digital and alarm indications, and contact outputs for remote alarms are provided for high radiation and failure conditions. Analog and digital outputs are provided to the CSB monitoring system. A computer data logging system is provided to record monitored functions for later download, as appropriate.

The GEMS assembly is an open frame skid and cabinet construction comprising of the following major subassemblies:

- Stack sample probe assembly

- Sampler skid assembly

- Control console.

The stack sample probe assembly is mounted directly to the stack by way of fittings welded to the stack. The sampler skid assembly is an open frame assembly suitable for concrete pad mounting. The sample skid allows easy stand up access to the sampler assemblies and is equipped with a work surface to facilitate periodic filter changeouts. The control console is designed for permanent tabletop or rack mounting, and is a National Electrical Manufacturer's Association (NEMA) 12 box assembly containing all major electronics and interface terminals. 


\section{SNF-4831 REV 0}

The control console is located in the CSB GEMS room and mounted on a tabletop for easy accessibility.

\subsubsection{Communications System}

The design of the CSB communications system provides the cabling and/or raceway system equipment for the telephone, public address, intercom, and radio communications systems within the CSB to the communications equipment interface point. All communications system physical interfaces are located in the communications area of the UPS room. A door from the electrical equipment room provides access to the UPS room. Space is provided for telephone exchange equipment, paging equipment, wire terminating frames, radio equipment, and coaxial and fiber-optic transmission equipment.

Telephone requirements are based on providing internal and external communications service to all office and operating areas within the CSB. The telephone system provides tie-ins to the Hanford Site crash alarm and the Hanford Site 911 emergency telephone system. An intercom system is incorporated into the telephone system.

Public address system coverage is required for all areas accessible to personnel, both interior and exterior. Public address systems within the CSB are accessed through specified telephone sets within the facility. Master overrides originate from the control room and the emergency response center. An evacuation alarm will be annunciated through the public address system speakers. The evacuation alarm can be activated from the control room or the emergency response center.

Area alarms are part of the 200 East alarm system and CSB alarms are incorporated into the DCS. Ringdown phones are installed for security use. Fire alarm and detection system signals are transmitted to the central fire alarm system by means of a radio system integral to the fire alarm control panel. Radiation and hazardous conditions alarms are annunciated by means of the DCS. The Hanford Site crash alarm in annunciated through the general CSB telephone system ringer and is directed to selected CSB telephones. 
Figure 2-1. Canister Storage Building.

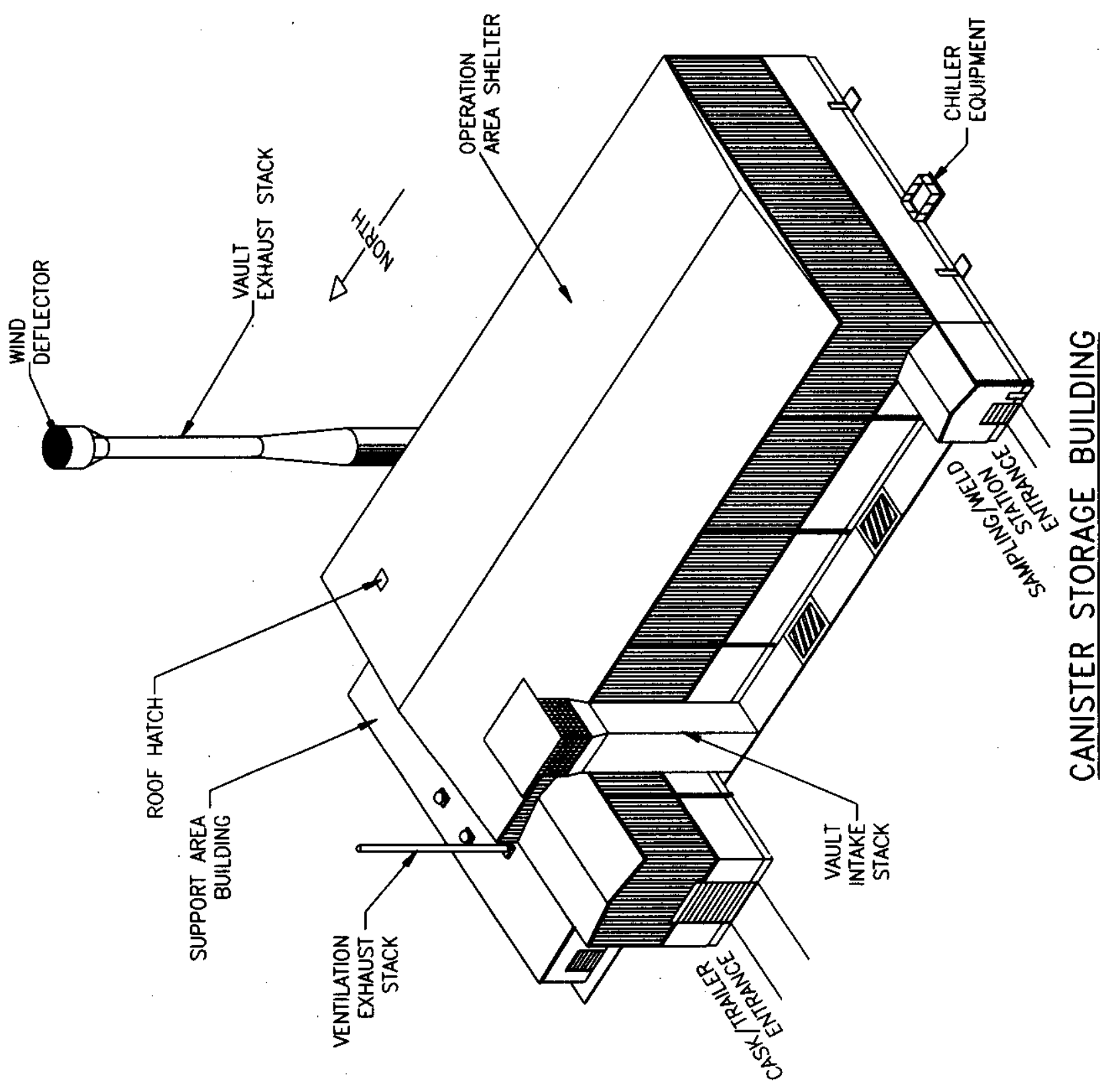


Figure 2-2. Canister Storage Building Operating Deck Plan View.

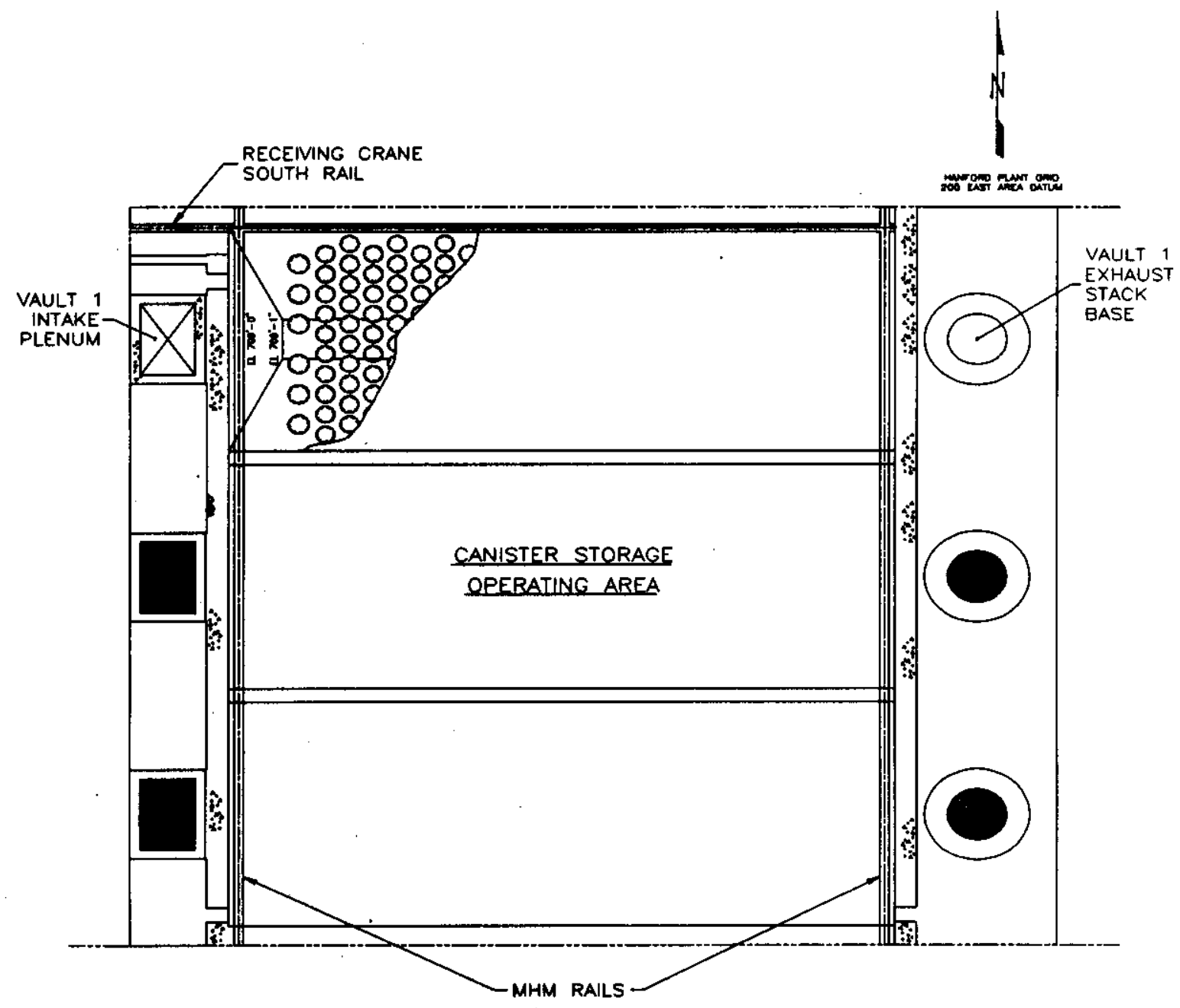

VAULT OPERATING AREA FLOOR PLAN 
Figure 2-3. Cask Transportation System Arrangement.
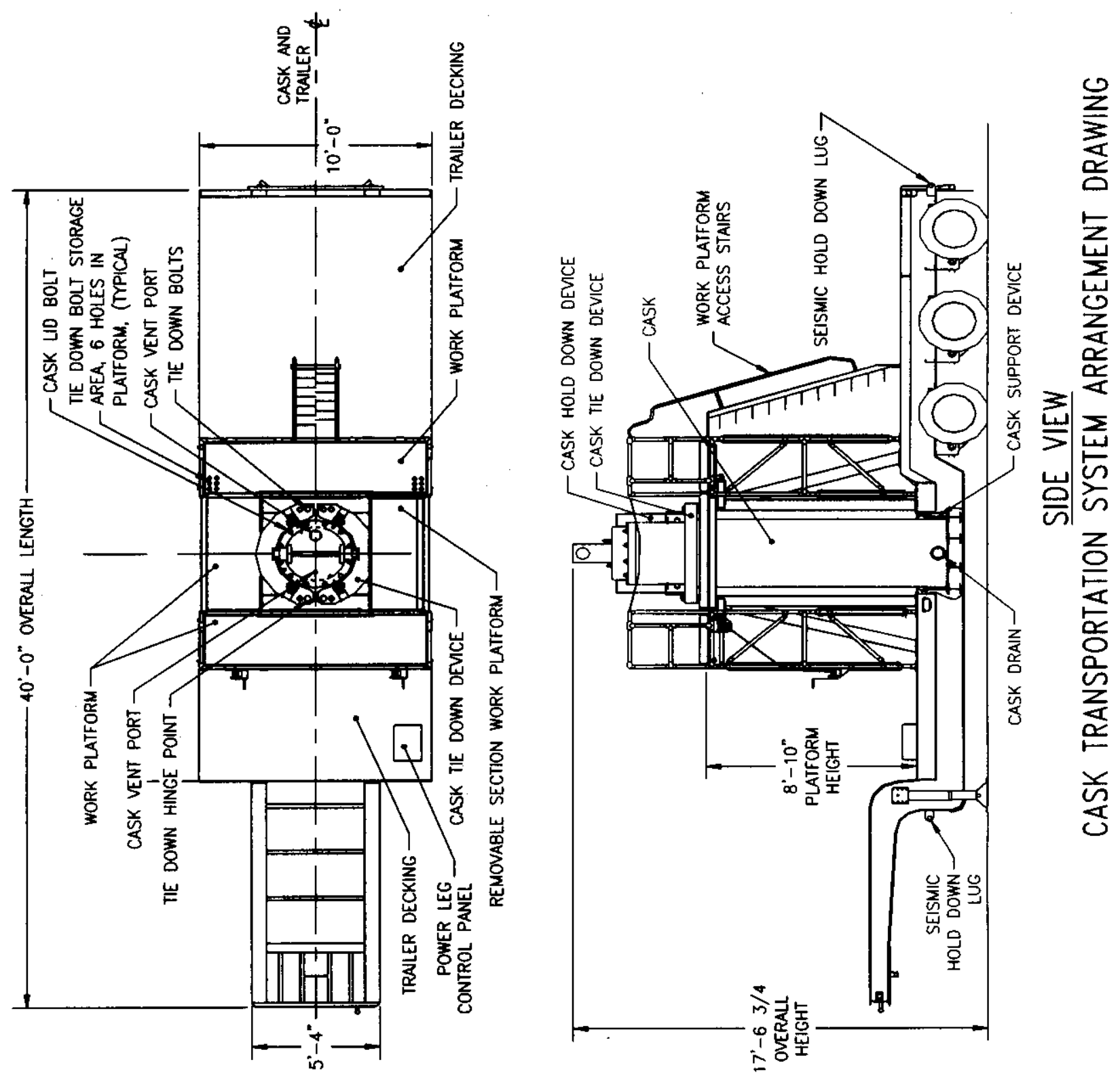


\section{SNF-4831 REV 0}

Figure 2-4. Cask Transportation Safety System Arrangement.

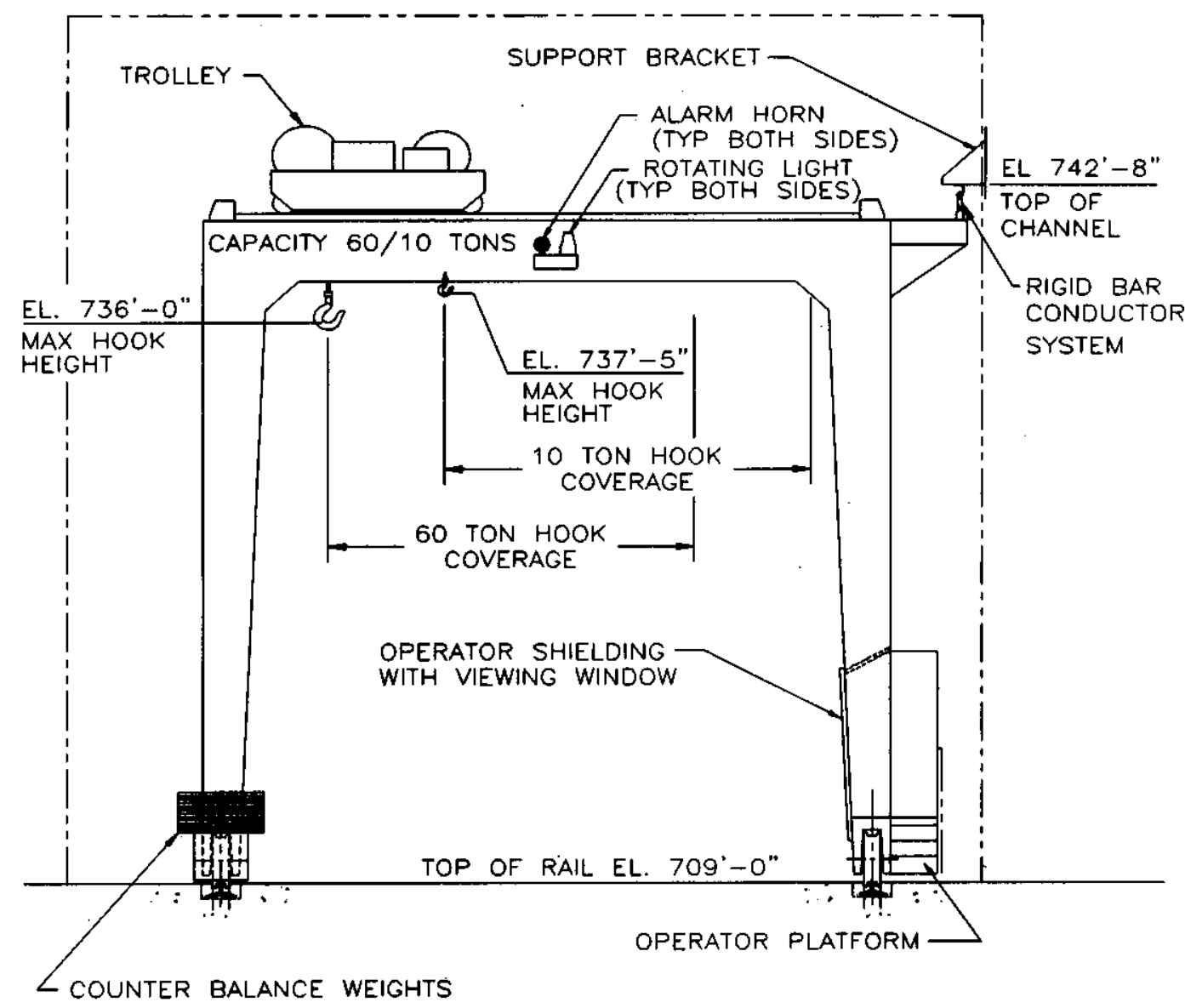

RECEIVING CRANE 
Figure 2-5. Service Pit Operations.
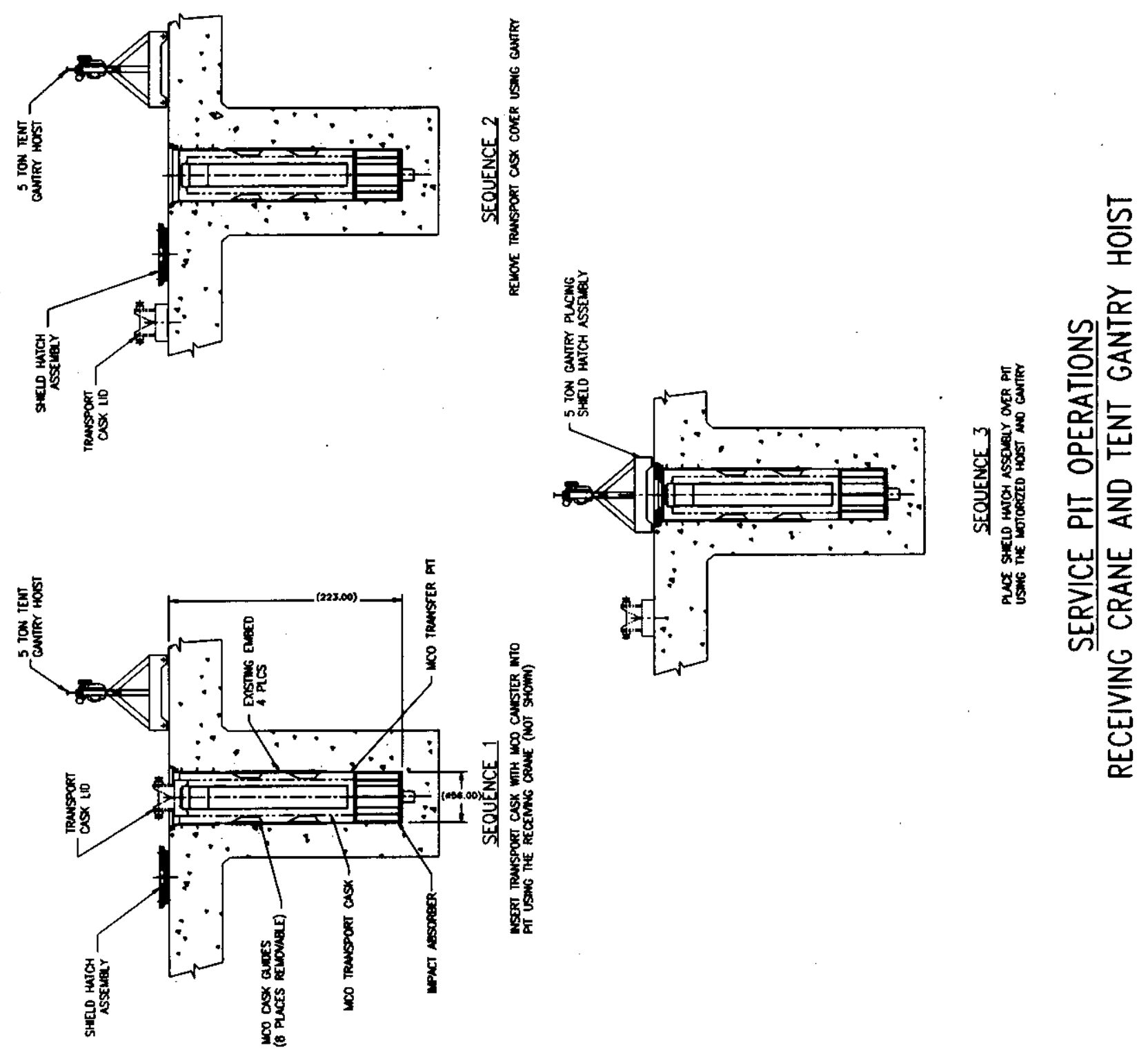
Figure 2-6. Multi-Canister Overpack Handling Machine.

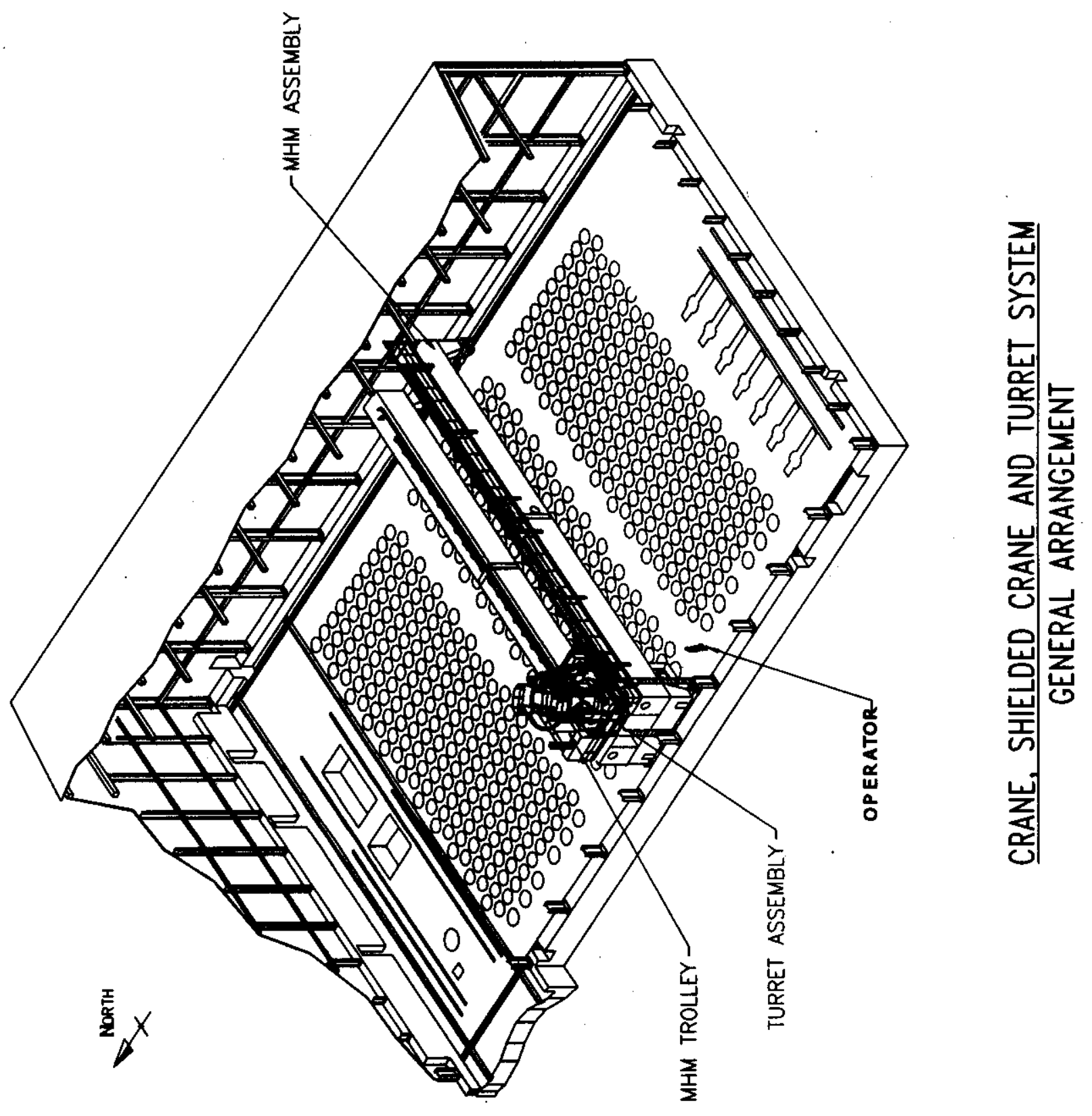


Figure 2-7. Multi-Canister Overpack Handling Machine Cask Turret Assembly.

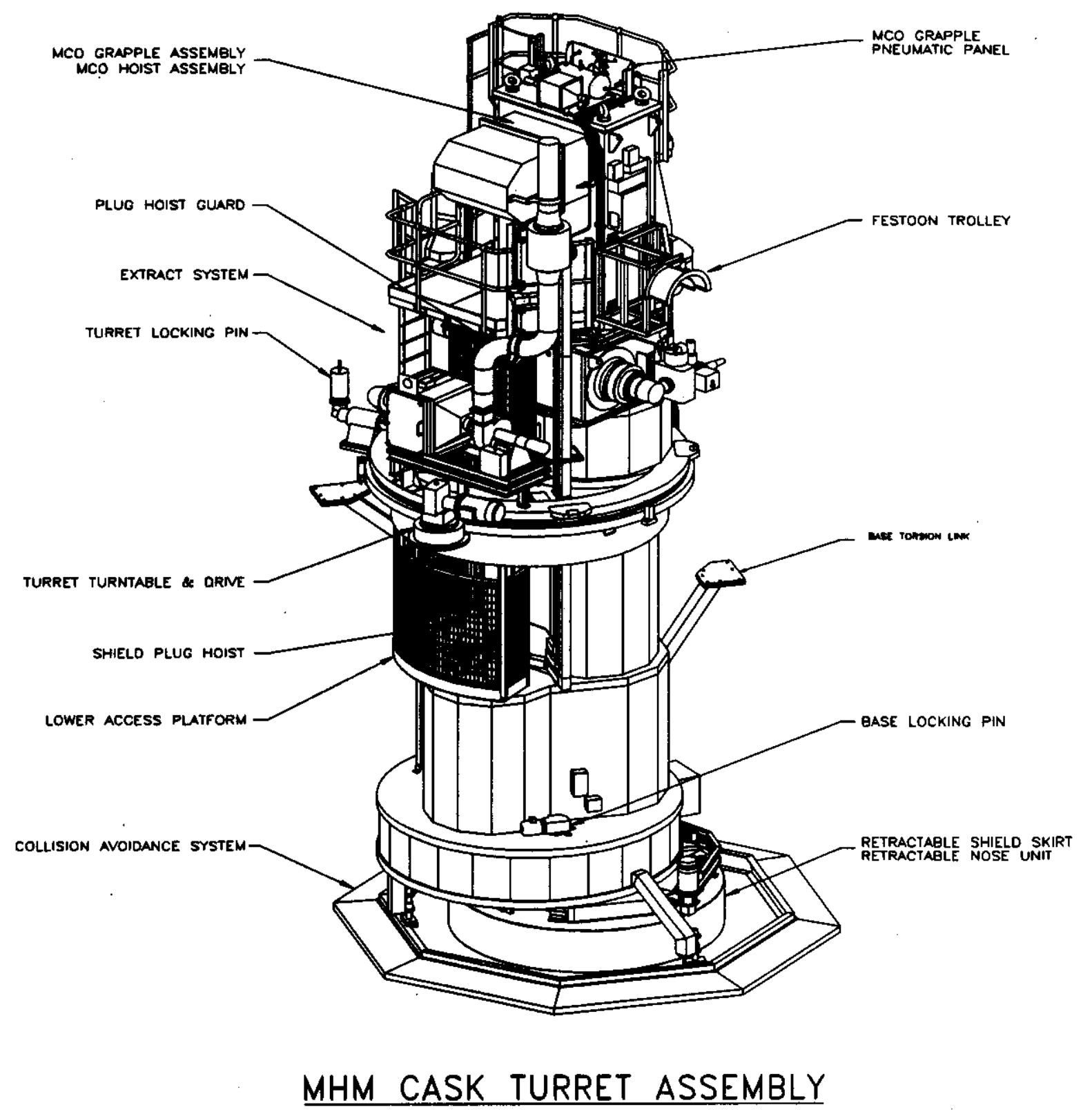


Figure 2-8. Multi-Canister Overpack Hoist Assembly.

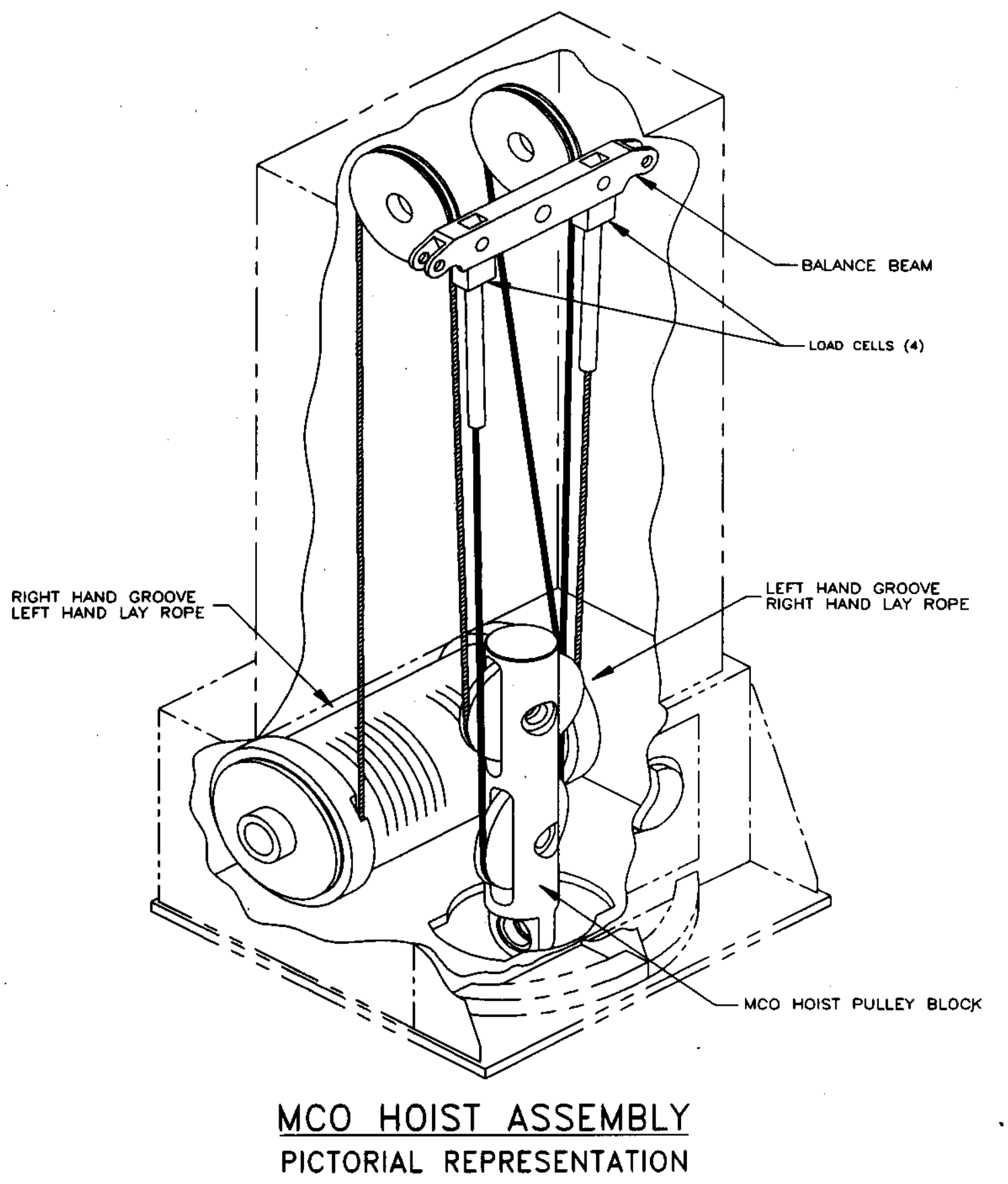


Figure 2-9. Tube Plug Grapple.

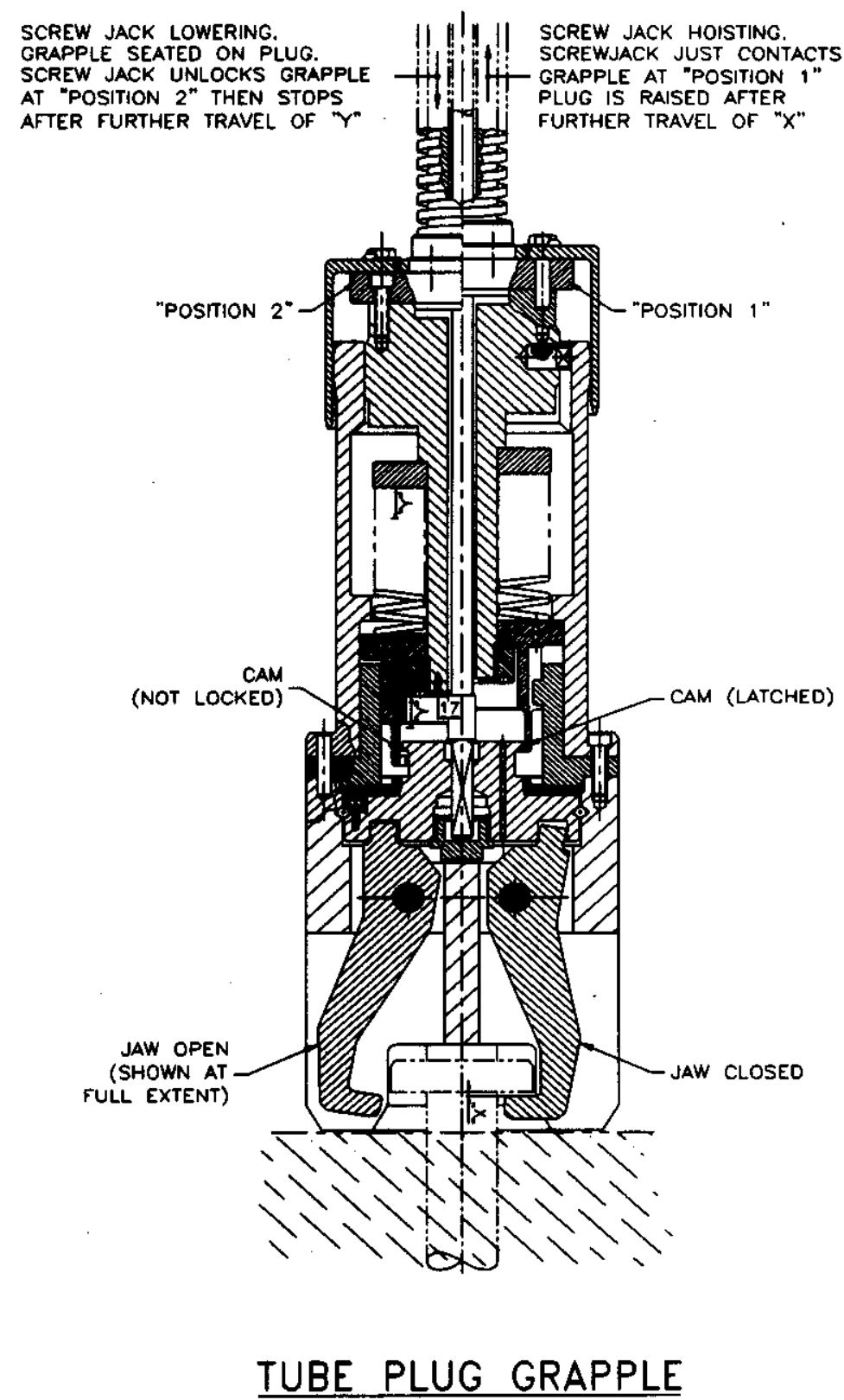


Figure 2-10. Multi-Canister Overpack Handling Machine Cask Shielding.

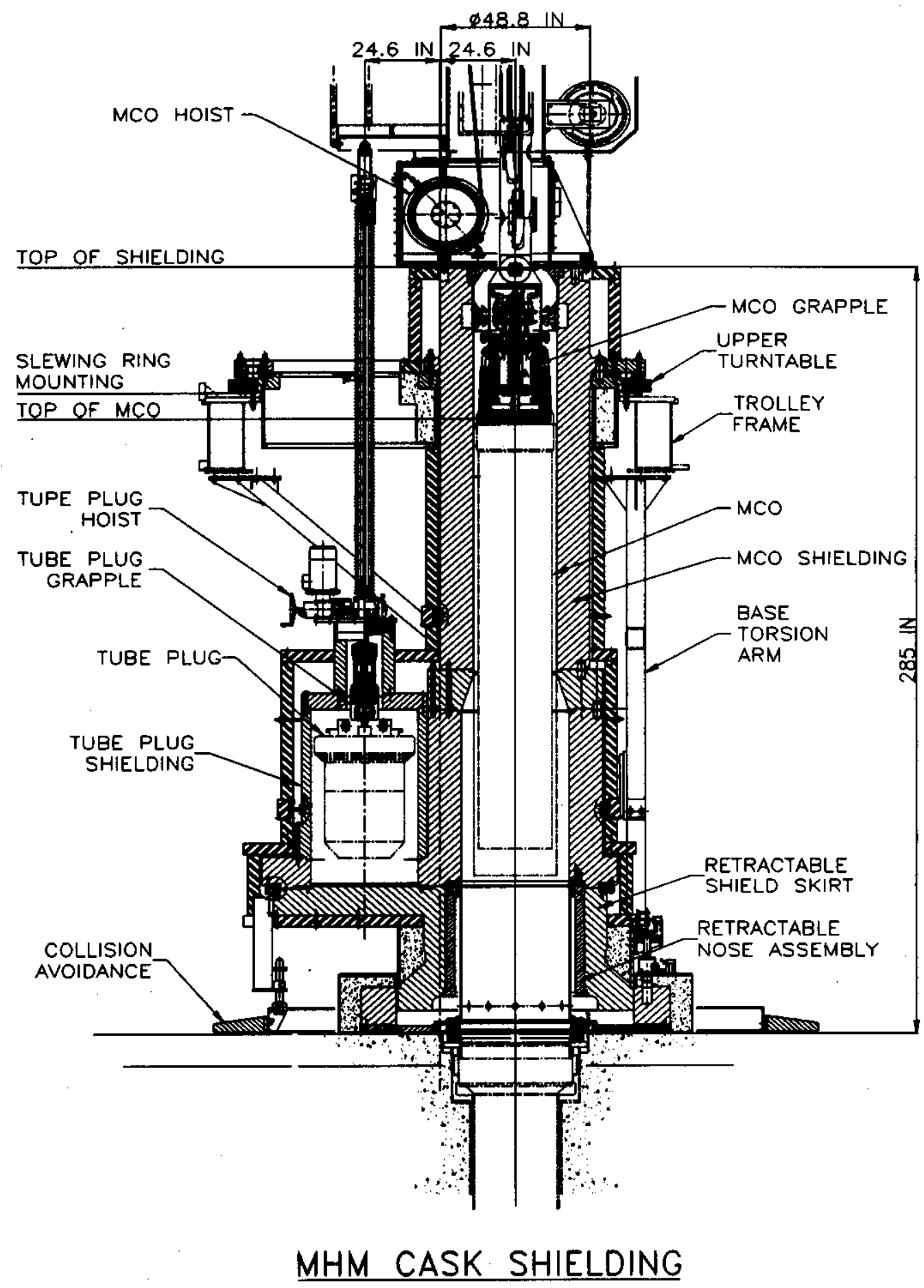


Figure 2-11. Sampling/Weld Station Gantry Crane.

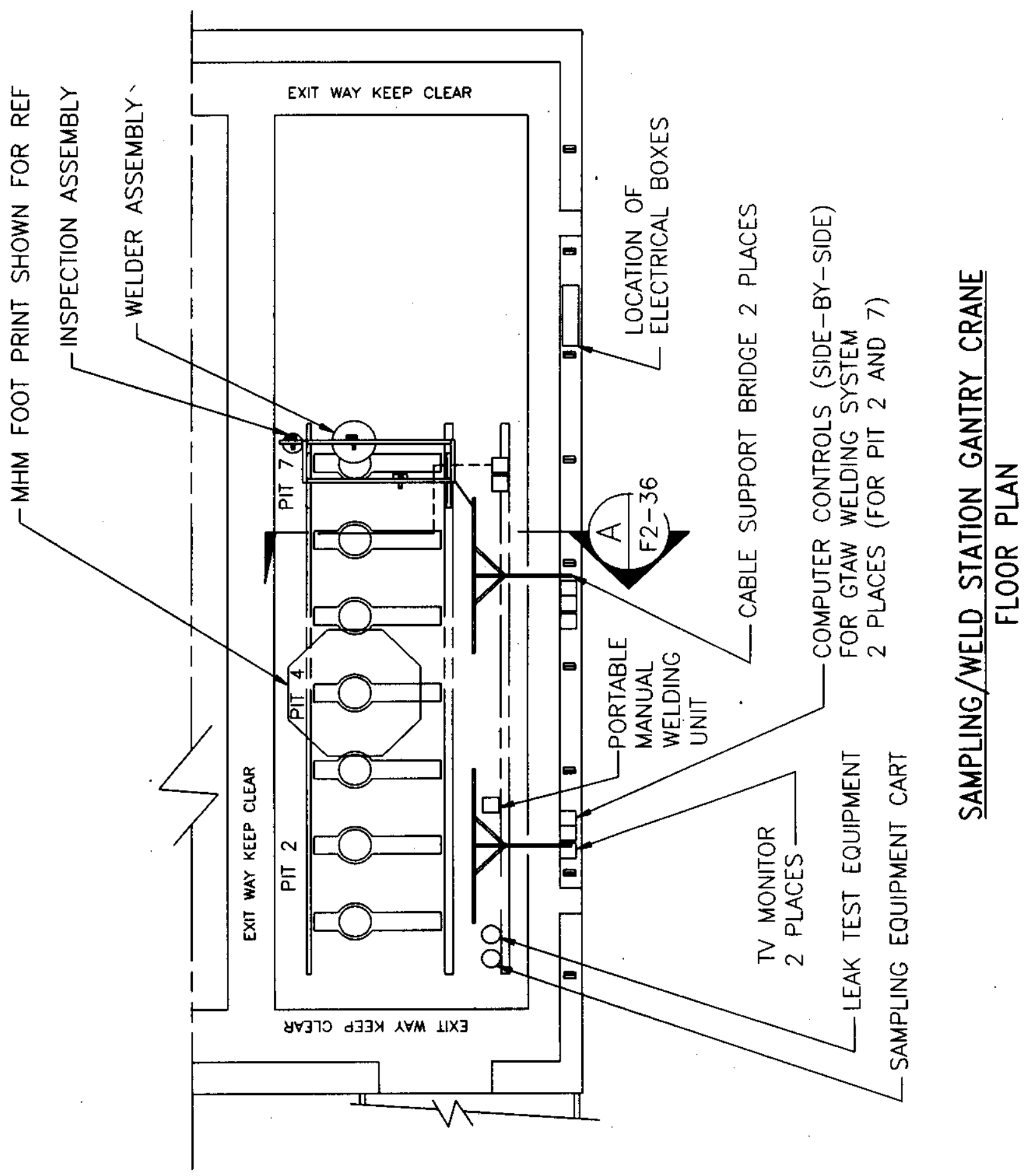


Figure 2-12. Multi-Canister Overpack in Sampling/Weld Pit.
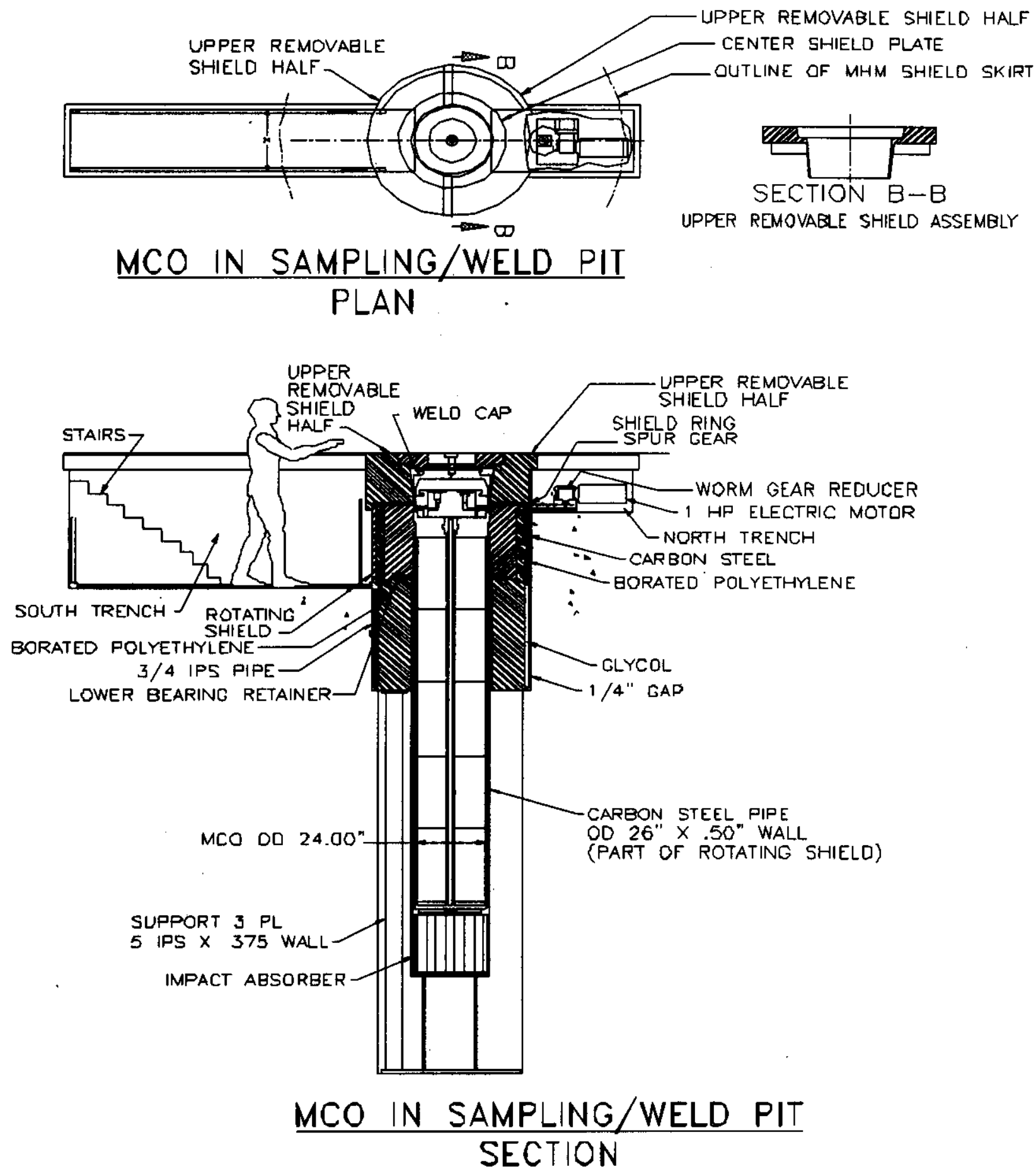
Figure 2-13. Tube Vent and Purge Cart. (sheet 1 of 2)
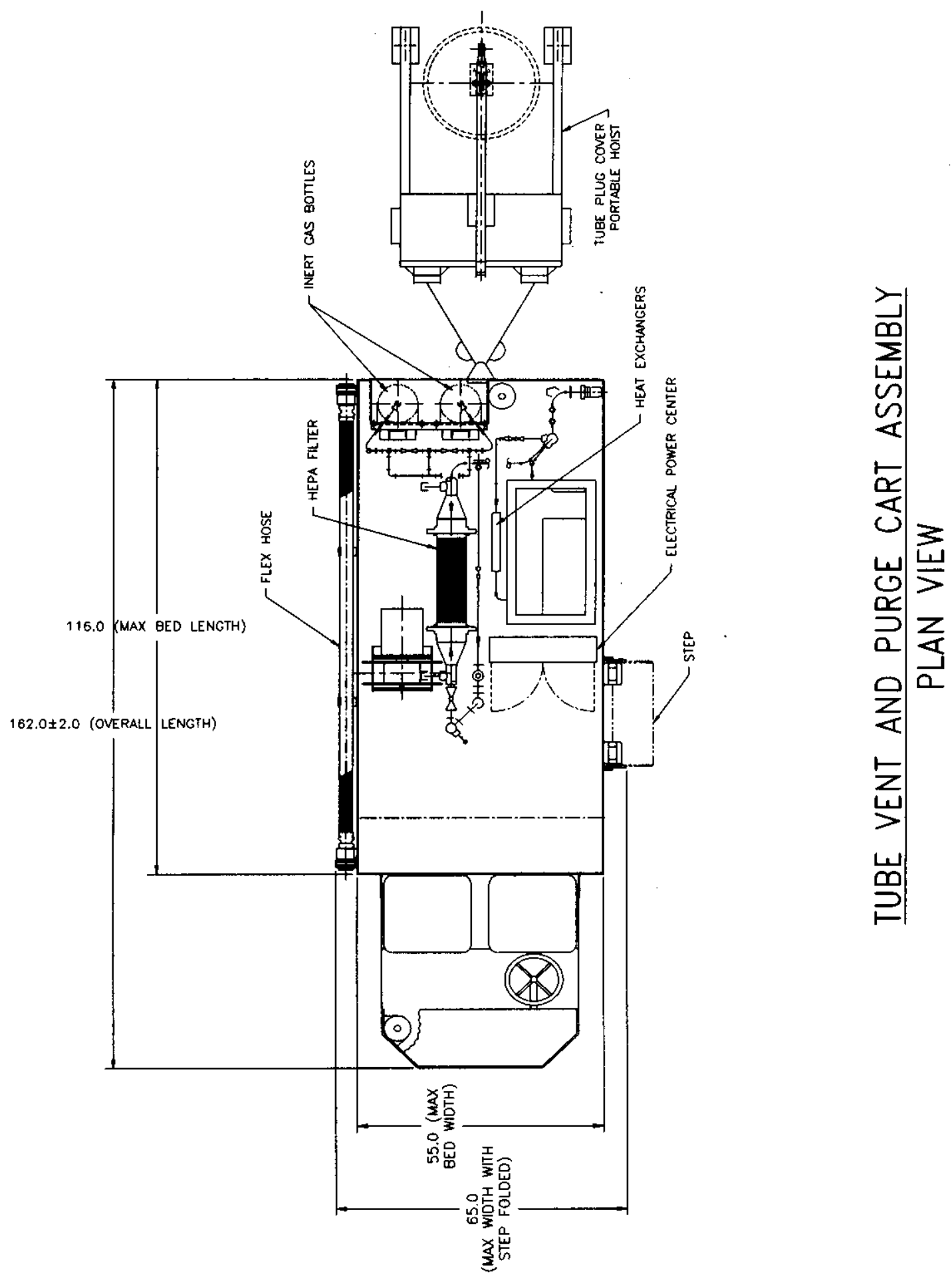
Figure 2-13. Tube Vent and Purge Cart. (sheet 2 of 2)

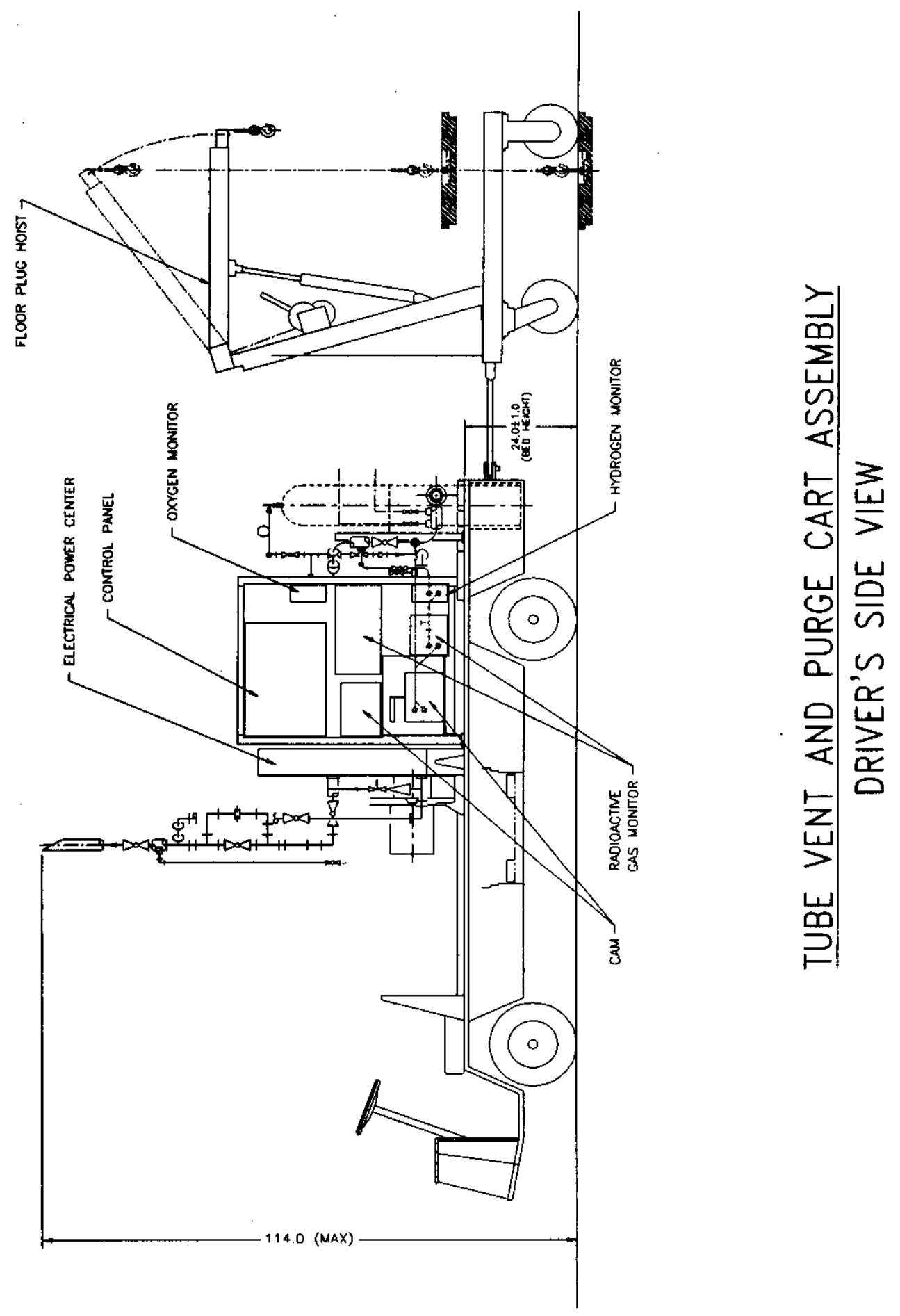


Figure 2-14. Distributed Control System.

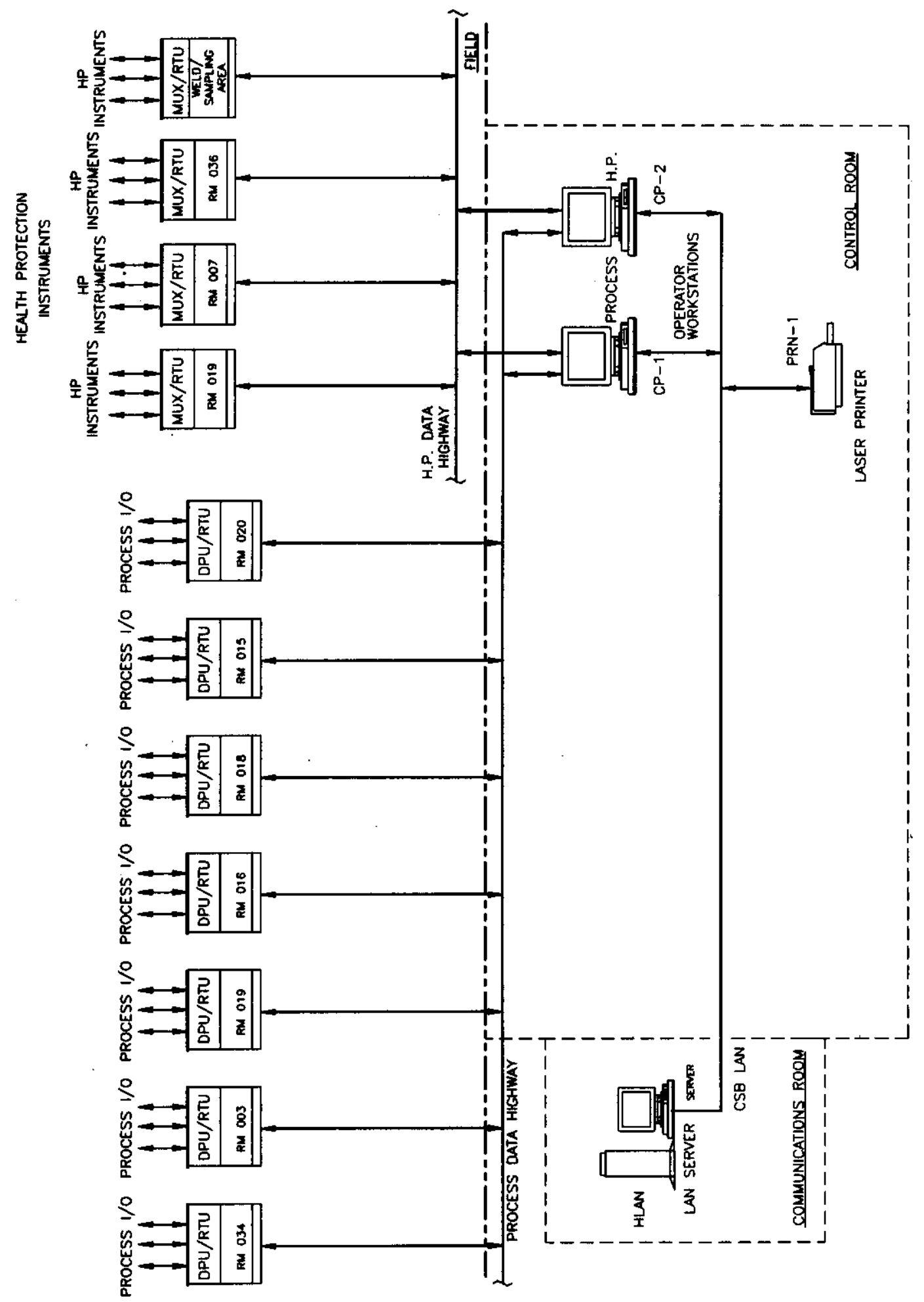

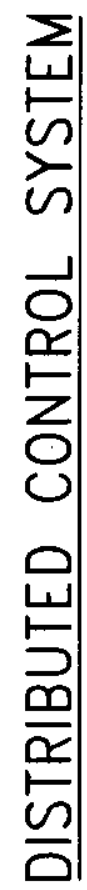




\section{SNF-4831 REV 0}

This page intentionally left blank. 


\subsection{CANISTER STORAGE BUILDING TOOLS STATUS}

Table 3-1 shows the numerous tools being procured or fabricated for the CSB. The table will indicate the tool/tool purpose, size of the tool, status of procuring the tool and any available comments. Tools are in various stages of design, for example, the rail frog lifting tool has not been conceptualized at this time, neither has the rail frog bolt tool. Some tools are procured "offthe-shelf." Some tooling is provided by the vendor.

Table 3-1. Canister Storage Building Tool Status. (5 sheets)

\begin{tabular}{|c|c|c|c|}
\hline Tool or Tool Purpose & $\begin{array}{l}\text { Tool Size } \\
(\mathrm{LxWxH}) \\
\text { or } \\
\text { Capacity } \\
\end{array}$ & Status & Comments \\
\hline $\begin{array}{l}\text { Wheel Chocks (set) (prevent } \\
\text { the trailer from rolling - } 1 \text { set } \\
\text { per trailer }\end{array}$ & N/A & No design. Off-the-shelf item. & \\
\hline $\begin{array}{l}\text { Trailer "bumper" ("stops" } \\
\text { prevent backing too far) }\end{array}$ & N/A & Designed. & \\
\hline $\begin{array}{l}\text { Exhaust trunk for tractor } \\
\text { (prevents exhaust from filling } \\
\text { the facility while trailer is } \\
\text { backed into the facility and } \\
\text { released from the tractor) }\end{array}$ & N/A & $\begin{array}{l}\text { Need to design to facility } \\
\text { interface. Trunks are off-the- } \\
\text { shelf items. }\end{array}$ & \\
\hline $\begin{array}{l}\text { Air Supply Gladhand for } \\
\text { inflation of trailer suspension } \\
\text { (connects facility air supply to } \\
\text { trailer) }\end{array}$ & $<0 \mathrm{ft}$. & $\begin{array}{l}\text { No design. Off-the-shelf item. } \\
\text { Need to determine length for } \\
\text { CSB. }\end{array}$ & \\
\hline $\begin{array}{l}\text { Cask secondary vent port } \\
\text { access tool (used with cask } \\
\text { section vent port filter system) } \\
\text { to inert cask before removing } \\
\text { cask lid. }\end{array}$ & & Design complete. & \\
\hline $\begin{array}{l}\text { Cask secondary vent port filter } \\
\text { system }\end{array}$ & & $\begin{array}{l}\text { Requirements for filter system } \\
\text { need to be determined. }\end{array}$ & \\
\hline $\begin{array}{l}\text { Cask secondary vent port dust } \\
\text { cap removal tool }\end{array}$ & & $\begin{array}{l}\text { MCE Part \# DES-2-010. } \\
\text { Prototype and first } 2 \text { available. } \\
\text { Need to procure } 3 \text { more. Store } \\
\text { this tool with trailer/cask. }\end{array}$ & \\
\hline $\begin{array}{l}\text { Fixture for cask lid (also used } \\
\text { to change seal and decon lower } \\
\text { surface) - supports cask lid } \\
\text { when removed from the cask }\end{array}$ & & Design completed. & $\begin{array}{l}\text { Need confirmation as to seal } \\
\text { change out and leak testing } \\
\text { requirements. }\end{array}$ \\
\hline $\begin{array}{l}\text { Cask lid automatic torque tool } \\
\text { (used to loosen or tighten cask } \\
\text { bolts) }\end{array}$ & & Factory complete. & $\begin{array}{l}\text { Lifting bail to be adjusted for } \\
\text { CSB. }\end{array}$ \\
\hline
\end{tabular}


Table 3-1. Canister Storage Building Tool Status. (5 sheets)

\begin{tabular}{|c|c|c|c|}
\hline Tool or Tool Purpose & $\begin{array}{c}\text { Tool Size } \\
(\mathrm{LxWxH}) \\
\text { or } \\
\text { Capacity }\end{array}$ & Status & Comments \\
\hline $\begin{array}{l}\text { Torque Calibration } \\
\text { tool/standard (used for cask lid } \\
\text { auto torque tool) }\end{array}$ & & & $\begin{array}{l}\text { Incorporated into previous } \\
\text { item. Torque calibration may } \\
\text { not be used at CSB. }\end{array}$ \\
\hline $\begin{array}{l}\text { Cart or Stand for Automatic } \\
\text { cask torque tool }\end{array}$ & & Design started. & Use with previous item. \\
\hline $\begin{array}{l}\text { Standard hand tools (electrical, } \\
\text { pneumatic, and mechanical) }\end{array}$ & & $\begin{array}{l}\text { Standard procurement. No } \\
\text { design; off-the-shelf item. }\end{array}$ & \\
\hline Cask lid lift feature & & Design completed. & $\begin{array}{l}\text { Used to remove cask lid to } \\
\text { containment tent. }\end{array}$ \\
\hline $\begin{array}{l}\text { Mobile Tent Gantry Hoist } \\
\text { Lifting Yoke }\end{array}$ & $1,800 \mathrm{lb}$ & $\begin{array}{l}\text { FDI Conceptual Design } \\
\text { complete. Ref: HNF-3553, } \\
\text { Figure A4-4 }\end{array}$ & $\begin{array}{l}\text { Needed for cask lid removal. } \\
\text { Needs to interface with mobile } \\
\text { gantry crane hoist. }\end{array}$ \\
\hline $\begin{array}{l}\text { Leak Check Equipment for } \\
\text { MCO port appliances and port } \\
\text { covers }\end{array}$ & & $\begin{array}{l}\text { Equipment required for MCO } \\
\text { port plug cover, and process } \\
\text { connector. Design started. }\end{array}$ & $\begin{array}{l}\text { For use at sampling/weld } \\
\text { station. }\end{array}$ \\
\hline Cask Lift Yoke & $60,000 \mathrm{lb}$ & $\begin{array}{l}\text { Requires modification or } \\
\text { replacement to fit } 150 \text {-ton } \\
\text { hoist. }\end{array}$ & \\
\hline Cask Lift Yoke stand & & Started. & \\
\hline Rail Frog Lifting Tool & & Started. & $\begin{array}{l}\text { Needs to include tooling for } \\
\text { unbolting and re-bolting } \\
\text { (torquing) the frogs. }\end{array}$ \\
\hline $\begin{array}{l}\text { Lifting Device for Service } \\
\text { Station Shield Hatch Assembly }\end{array}$ & $10,000 \mathrm{Ib}$ & & $\begin{array}{l}\text { Needs to work with mobile } \\
\text { service station gantry crane } \\
\text { and hoist (CRN-008) }\end{array}$ \\
\hline $\begin{array}{l}\text { MHM/Tube Interface Ring } \\
\text { Lifting device }\end{array}$ & & & $\begin{array}{l}\text { Needs to interface with the } \\
\text { Tube vent and Purge Cart } \\
\text { hoist. Can be the same as tube } \\
\text { plug cover lifting device. }\end{array}$ \\
\hline $\begin{array}{l}\text { Tube Plug Unlock/Lock Tool } \\
\text { (overpack tubes only) }\end{array}$ & & Determine if needed. & $\begin{array}{l}\text { Overpack tube plug lock down } \\
\text { device uses hand knob } \\
\text { assembly. }\end{array}$ \\
\hline \multicolumn{4}{|l|}{$\begin{array}{l}\text { Tube Plug Seal Test Apparatus } \\
\text { (overpack tubes only) }\end{array}$} \\
\hline $\begin{array}{l}\text { Empty MCO Handling Fixtures } \\
\text { (used to handle new or empty } \\
\text { MCOs before they are initially } \\
\text { placed in the cask) }\end{array}$ & & $\begin{array}{l}\text { No design required; off-the- } \\
\text { shelf item. }\end{array}$ & $\begin{array}{l}\text { Analysis completed to verify } \\
\text { MCO will not be damaged by } \\
\text { tool. }\end{array}$ \\
\hline $\begin{array}{l}\text { MCO Port Cover Removal and } \\
\text { Installation Tool }\end{array}$ & & $\begin{array}{l}\text { No design required; off-the- } \\
\text { shelf item. }\end{array}$ & $\begin{array}{l}\text { For use at the sampling/weld } \\
\text { station. }\end{array}$ \\
\hline
\end{tabular}


Table 3-1. Canister Storage Building Tool Status. (5 sheets)

\begin{tabular}{|c|c|c|c|}
\hline Tool or Tool Purpose & $\begin{array}{l}\text { Tool Size } \\
\text { (LxWxH) } \\
\text { or } \\
\text { Capacity } \\
\end{array}$ & Status & Comments \\
\hline $\begin{array}{l}\text { Tools to replace Tube Plug } \\
\text { seals }\end{array}$ & & $\begin{array}{l}\text { No design required. Standard } \\
\text { procurement. }\end{array}$ & \\
\hline $\begin{array}{l}\text { Tools to Replace Filters and } \\
\text { Valves on Tube Plug }\end{array}$ & & $\begin{array}{l}\text { No design required. Standard } \\
\text { procurement. }\end{array}$ & \\
\hline $\begin{array}{l}\text { Standard and Overpack Tube } \\
\text { Covers lifting devices }\end{array}$ & $1.500 \mathrm{Ib}$ & & $\begin{array}{l}\text { Need to interface with the } \\
\text { Tube Vent and Purge Cart } \\
\text { hoist. Can be same as } \\
\text { Tube/MHM interface guide } \\
\text { ring lifting device. }\end{array}$ \\
\hline Service Cart special tools & & Included with cart procurement & \\
\hline $\begin{array}{l}\text { Specialized Handling Tools for } \\
\text { Facility HEPA filters. }\end{array}$ & & No special tools required. & \\
\hline Special MFM tools & & $\begin{array}{l}\text { Included with MHM } \\
\text { procurement. }\end{array}$ & \\
\hline $\begin{array}{l}\text { Fixture to Change Tube Plug } \\
\text { Seals in MHM Maintenance Pit }\end{array}$ & & Not started. & \\
\hline $\begin{array}{l}\text { Fittings to Refill Helium } \\
\text { Cylinders On Service Carts } \\
\text { from Building Gas Supply }\end{array}$ & & Design complete. & \\
\hline Empty MCO Storage Carts & & Design started. & \\
\hline $\begin{array}{l}\text { Storage Rack for MHM } \\
\text { Maintenance Pit Tools }\end{array}$ & & & \\
\hline $\begin{array}{l}\text { Handling fixtures for MHM } \\
\text { special tools }\end{array}$ & & & \\
\hline Impact Limiter Handling Tool & & Design completed. & $\begin{array}{l}\text { For lowering impact lifter } \\
\text { placement without using } \\
\text { MHM. }\end{array}$ \\
\hline Tools for welding cover cap & & Not started. & Welding Contractor scope? \\
\hline $\begin{array}{l}\text { Leakage Rate Collar tools } \\
\text { 1. Mechanical Seal Collar } \\
\text { 2. Cover cap weld collar } \\
\text { 3. Cover cap Port cover } \\
\text { (possible) }\end{array}$ & & Design started. & \\
\hline $\begin{array}{l}\text { Tool for Lifting the } \\
\text { Sampling/weld station cover } \\
\text { plug assembly }\end{array}$ & & Conceptual Design complete. & $\begin{array}{l}\text { Sampling/weld station center } \\
\text { shield plate interfaces with } \\
\text { MFM tube plug grapple. }\end{array}$ \\
\hline \multicolumn{4}{|l|}{ Radiation survey/swipe tools } \\
\hline Sample Transfer? & & Design required. & $\begin{array}{l}\text { For use in transferring } \\
\text { He/MCO gas samples. }\end{array}$ \\
\hline
\end{tabular}




\section{SNF-4831 REV 0}

Table 3-1. Canister Storage Building Tool Status. (5 sheets)

\begin{tabular}{|c|c|c|c|}
\hline Tool or Tool Purpose & $\begin{array}{l}\text { Tool Size } \\
\text { (LxWxH) } \\
\text { or } \\
\text { Capacity }\end{array}$ & Status & Comments \\
\hline $\begin{array}{l}\text { Load test weights for weld } \\
\text { station gantry cranes }\end{array}$ & & $\begin{array}{l}\text { No design required; standard } \\
\text { procurement. }\end{array}$ & \\
\hline Pallets for weld caps & $500 \mathrm{tb}$ ea. & $\begin{array}{l}\text { No design; standard aluminum } \\
\text { pallets. }\end{array}$ & \\
\hline MCO Process valve operator & & Design complete. & $\begin{array}{l}\text { needs to interface with MCO } \\
\text { sample station. }\end{array}$ \\
\hline $\begin{array}{l}\text { Lift fixture for temporary } \\
\text { shielding }\end{array}$ & & Design complete. & $\begin{array}{l}\text { Needs to interface with } \\
\text { Sampling/Weld station gantry } \\
\text { crane. Welding contractor } \\
\text { scope. }\end{array}$ \\
\hline $\begin{array}{l}\text { Panel cover for trailer operating } \\
\text { mechanisms }\end{array}$ & & Complete. & \\
\hline Cask Vent Port/Test Tool & & Design complete. & $\begin{array}{l}\text { Interfaces with cask pressure } \\
\text { test tool and cask servicing } \\
\text { system. }\end{array}$ \\
\hline Cask Pressure Test Tool & & & $\begin{array}{l}\text { Interfaces with Cask vent } \\
\text { port/test tool. }\end{array}$ \\
\hline
\end{tabular}

N/A = not applicable 


\subsection{CANISTER STORAGE BUILDING HAZARD ANALYSIS}

HNF-SD-SNF-HIE-001, Canister Storage Building Hazard Analysis and SNF 3907 are reviewed. The CSB hazard analysis covered normal, intended, CSB operations for handling and storing a sealed MCO. Also identified and analyzed were the potential hazards associated with storing an off-normal MCO in an overpack storage tube following undetermined accident recovery actions. The following normal CSB operations were considered:

- Receiving the transporter containing the cask-MCO and moving it into the facility

- Moving the cask-MCO to the service area and removing the cask lid

- Transporting the MCO from the service area to the storage tube with the MCO MHM

- Transporting the MCO from the storage tube to the MCO sampling/weld station and returning it to the storage tube after sampling

- Conducting activities during MCO staging and interim storage.

The following off-normal MCO storage operations were also considered:

- The event or accident leading to MCO damage has been terminated and recovery actions completed

- The off-normal MCO is in place in the overpack storage tube

- The overpack storage tube plug cover is installed

- An inert atmosphere has been established in the overpack tube.

The hazard identification process systematically and comprehensively identified hazards that can contribute to the uncontrolled release of radioactive or hazardous materials or that can threaten the safety of facility workers. The hazard evaluation process identified hazardous conditions, determined causes and preventive and mitigative features, and qualitatively estimated the frequency and consequences of occurrence. In addition to credited prevention, mitigation, and defense-in-depth or worker safety features, additional mitigating considerations are now offered from the HFE/Erg analysis.

Table 4-1, CSB Hazard Analysis Table (Human Error), presents results for only those hazards associated with human error. The Hazard Analysis Table is abbreviated from the table found in HNF-SD-SNF-HIE-001. The Hazard Analysis Table covers the following seven CSB areas:

- $\quad$ Truck Vestibule (TV) 
- $\quad$ Service Area (SA)

- Operating Area, including overpack storage tubes and tube vent and purge cart (OA)

- $\quad$ Sampling/Weld Station (WS)

- $\quad$ Vault (VL)

- $\quad$ Support Building (SB)

- Outside (OU).

Table 4-1. Canister Storage Building Hazard Analysis Table (Human Error). (14 sheets)

\begin{tabular}{|c|c|c|c|c|c|}
\hline $\begin{array}{c}\text { Location/ } \\
\text { Checklist } \\
\text { entry }\end{array}$ & $\begin{array}{l}\text { Hazardous } \\
\text { Condition }\end{array}$ & $\begin{array}{l}\text { Credited } \\
\text { Prevention }\end{array}$ & $\begin{array}{l}\text { Credited } \\
\text { Mitigation }\end{array}$ & $\begin{array}{l}\text { Defense-in-depth or } \\
\text { worker safety features }\end{array}$ & $\begin{array}{l}\text { HFE/Erg evaluation } \\
\text { addition mitigators to } \\
\text { consider }\end{array}$ \\
\hline TV-F-01 & $\begin{array}{l}\text { Transporter } \\
\text { collision }\end{array}$ & & & $\begin{array}{l}\text { The truck vestibule has } \\
\text { wheel stops to alert the } \\
\text { drive to his position. } \\
\text { The approach into the } \\
\text { truck vestibule is } \\
\text { restricted by design speed } \\
\text { and includes speed limits. } \\
\text { The drivers of the } \\
\text { transporters are trained } \\
\text { and qualified to perform } \\
\text { their duties safely. } \\
\text { Packaging controls limit } \\
\text { the conditions under } \\
\text { which a transporter could } \\
\text { arrive at the CSB. } \\
\text { Regular maintenance is } \\
\text { performed on the } \\
\text { transporter to ensure it is } \\
\text { in good working order. }\end{array}$ & $\begin{array}{l}\text { Provide a second person } \\
\text { to direct the transporter } \\
\text { driver while in or } \\
\text { around the truck } \\
\text { vestibule. } \\
\text { Provide written } \\
\text { guidelines for truck } \\
\text { operations in and around } \\
\text { the CSB. }\end{array}$ \\
\hline
\end{tabular}


Table 4-1. Canister Storage Building Hazard Analysis Table (Human Error). (14 sheets)

\begin{tabular}{|c|c|c|c|c|c|}
\hline $\begin{array}{l}\text { Location/ } \\
\text { Checklist } \\
\text { entry }\end{array}$ & $\begin{array}{l}\text { Hazardous } \\
\text { Condition }\end{array}$ & $\begin{array}{l}\text { Credited } \\
\text { Prevention }\end{array}$ & $\begin{array}{l}\text { Credited } \\
\text { Mitigation }\end{array}$ & $\begin{array}{l}\text { Defense-in-depth or } \\
\text { worker safety features }\end{array}$ & $\begin{array}{l}\mathrm{HFE} / \mathrm{Erg} \text { evaluation } \\
\text { addition mitigators to } \\
\text { consider }\end{array}$ \\
\hline TV-F-05 & $\begin{array}{l}\text { Crane } \\
\text { collision }\end{array}$ & & : & $\begin{array}{l}\text { The receiving crane } \\
\text { design includes such } \\
\text { features as restricted } \\
\text { speed, load float, } \\
\text { microprocessor, and } \\
\text { auditory movement } \\
\text { alarms. } \\
\text { The operators of the } \\
\text { receiving crane are } \\
\text { trained and qualified to } \\
\text { perform their duties } \\
\text { safely. } \\
\text { Regular maintenance is } \\
\text { performed on the } \\
\text { receiving crane to ensure } \\
\text { it is in good working } \\
\text { order. }\end{array}$ & $\begin{array}{l}\text { Redesign of crane } \\
\text { controls to avoid } \\
\text { inadvertent or wrong } \\
\text { actuation's or } \\
\text { movements. } \\
\text { Provide a second person } \\
\text { to direct and guide the } \\
\text { crane operator. } \\
\text { Provide written } \\
\text { guidelines for the } \\
\text { receiving crane } \\
\text { operations. }\end{array}$ \\
\hline TV-F-06 & $\begin{array}{l}\text { Gas Bottles } \\
\text { collision or } \\
\text { impact }\end{array}$ & & $\begin{array}{l}\text { Site maintenance } \\
\text { program prohibits } \\
\text { maintenance on the } \\
\text { bottles }\end{array}$ & $\begin{array}{l}\text { All gas bottles except } \\
\text { carbon dioxide fire } \\
\text { extinguisher bottles have } \\
\text { orifices that restrict the } \\
\text { velocity of exiting gas. }\end{array}$ & $\begin{array}{l}\text { Conduct routine visual } \\
\text { inspection of bottles. } \\
\text { Chain down stored } \\
\text { bottles. }\end{array}$ \\
\hline TV-F-09 & $\begin{array}{l}\text { Cask falls off } \\
\text { transporter } \\
\text { after the } \\
\text { clamshell hold } \\
\text { downs are } \\
\text { removed but } \\
\text { before the } \\
\text { yoke is } \\
\text { attached }\end{array}$ & & • & $\begin{array}{l}\text { The operators of the } \\
\text { receiving crane are } \\
\text { trained and qualified to } \\
\text { perform their duties } \\
\text { safely, which includes } \\
\text { following procedures for } \\
\text { safe handling of the } \\
\text { transportation cask. } \\
\text { Regular maintenance is } \\
\text { performed on the } \\
\text { transporter to ensure it is } \\
\text { in good working order. }\end{array}$ & \\
\hline
\end{tabular}


Table 4-1. Canister Storage Building Hazard Analysis Table (Human Error). (14 sheets)

\begin{tabular}{|c|c|c|c|c|c|}
\hline $\begin{array}{l}\text { Location/ } \\
\text { Checklist } \\
\text { entry }\end{array}$ & $\begin{array}{l}\text { Hazardous } \\
\text { Condition }\end{array}$ & $\begin{array}{l}\text { Credited } \\
\text { Prevention }\end{array}$ & $\begin{array}{l}\text { Credited } \\
\text { Mitigation }\end{array}$ & $\begin{array}{l}\text { Defense-in-depth or } \\
\text { worker safety features }\end{array}$ & $\begin{array}{l}\text { HFE/Erg evaluation } \\
\text { addition mitigators to } \\
\text { consider }\end{array}$ \\
\hline TV-F-13 & $\begin{array}{l}\text { Cask falls } \\
\text { from receiving } \\
\text { crane }\end{array}$ & & & $\begin{array}{l}\text { The operators of the } \\
\text { receiving crane are } \\
\text { trained and qualified to } \\
\text { perform their duties } \\
\text { safely, which includes } \\
\text { following procedures for } \\
\text { safe handling of the } \\
\text { transportation cask. } \\
\text { Maintenance and } \\
\text { operations manuals and } \\
\text { details are to be provided } \\
\text { by crane vendors. } \\
\text { The hoist design includes: } \\
\text { Interlocks to preclude lift } \\
\text { and horizontal motion at } \\
\text { the same time } \\
\text { dual brakes } \\
\text { no free-fall capacity }\end{array}$ & $\begin{array}{l}\text { Better visibility of hook } \\
\text { by the crane operator } \\
\text { during lifting operations. } \\
\text { Provide a second person } \\
\text { to direct and guide the } \\
\text { crane operator. }\end{array}$ \\
\hline TV-J-07 & $\begin{array}{l}\text { Flammable } \\
\text { gas in the } \\
\text { truck } \\
\text { vestibule } \\
\text { ignites }\end{array}$ & & & $\begin{array}{l}\text { This hazard is within the } \\
\text { envelope of the cask } \\
\text { Safety Analysis Report for } \\
\text { Packaging for external } \\
\text { fires. }\end{array}$ & $\begin{array}{l}\text { Remove flammable gas } \\
\text { prior to bringing in a } \\
\text { cask. } \\
\text { Restrict smoking. } \\
\text { Have a dedicated space } \\
\text { for gas bottles. }\end{array}$ \\
\hline
\end{tabular}


Table 4-1. Canister Storage Building Hazard Analysis Table (Human Error). (14 sheets)

\begin{tabular}{|c|c|c|c|c|c|}
\hline $\begin{array}{l}\text { Location/ } \\
\text { Checklist } \\
\text { entry }\end{array}$ & $\begin{array}{l}\text { Hazardous } \\
\text { Condition }\end{array}$ & $\begin{array}{l}\text { Credited } \\
\text { Prevention }\end{array}$ & $\begin{array}{l}\text { Credited } \\
\text { Mitigation }\end{array}$ & $\begin{array}{l}\text { Defense-in-depth or } \\
\text { worker safety features }\end{array}$ & $\begin{array}{l}\text { HFE/Brg evaluation } \\
\text { addition mitigators to } \\
\text { consider }\end{array}$ \\
\hline SA-E-07 & $\begin{array}{l}\text { Rotating turret } \\
\text { creates a } \\
\text { shearing force } \\
\text { on a lowered } \\
\text { MCO or on } \\
\text { the supporting } \\
\text { lifting cable } \\
\text { and pneumatic } \\
\text { lines of the } \\
\text { MHM }\end{array}$ & . & & $\begin{array}{l}\text { Personnel are trained to } \\
\text { MHM-specific procedures } \\
\text { for safe operation. } \\
\text { Interlocks (electrical and } \\
\text { mechanical) prohibit any } \\
\text { horizontal movement, } \\
\text { linear or rotational, while } \\
\text { an MCO is loaded but not } \\
\text { fully raised. } \\
\text { MHM resolver indicates } \\
\text { MCO's relative position } \\
\text { within the service station } \\
\text { pit and/or MHM while it } \\
\text { is being raised. } \\
\text { The MHM is provided } \\
\text { with backup grapple } \\
\text { disengagement capability. } \\
\text { The MHM-service station } \\
\text { pit interface provides } \\
\text { active HEPA-filtered } \\
\text { ventilation. }\end{array}$ & $\begin{array}{l}\text { Provide a second person } \\
\text { on the floor to view the } \\
\text { status of the MCO and } \\
\text { feedback to MHM } \\
\text { operator. } \\
\text { Additional visibility of } \\
\text { the MCO and lines } \\
\text { provided to the MHM } \\
\text { operator during } \\
\text { movement. }\end{array}$ \\
\hline SA-F-05 & $\begin{array}{l}\text { MHM collides } \\
\text { with cask- } \\
\text { MCO as it is } \\
\text { being } \\
\text { lowering into } \\
\text { MCO service } \\
\text { pit by the } \\
\text { receiving } \\
\text { crane }\end{array}$ & . & & $\begin{array}{l}\text { Electrical interlocks } \\
\text { relative to receiving crane } \\
\text { and MHM positioning } \\
\text { along their respective } \\
\text { tracks preclude the } \\
\text { presence of both the } \\
\text { MHM and the receiving } \\
\text { crane in the service area } \\
\text { simultaneously. } \\
\text { Personnel are trained to } \\
\text { procedures detailing the } \\
\text { safe sequence of } \\
\text { operations. These } \\
\text { procedures prohibit } \\
\text { interference between the } \\
\text { receiving crane and the } \\
\text { MHM. } \\
\text { The frogs on the receiving } \\
\text { crane's tracks have stops. } \\
\text { The receiving crane has } \\
\text { auditory indication of its } \\
\text { movement (i.e., alarms). } \\
\text { The receiving crane is } \\
\text { limited to relatively slow } \\
\text { movement. }\end{array}$ & $\begin{array}{l}\text { Provide a second person } \\
\text { on the floor to look for } \\
\text { indication of possible } \\
\text { collisions } \\
\text { Proximity wires around } \\
\text { the receiving crane and } \\
\text { the MHM to } \\
\text { automatically top } \\
\text { horizontal travel } \\
\text { Rail frog designed to } \\
\text { preclude inappropriate } \\
\text { positioning } \\
\text { Rail frog position } \\
\text { indicator light or panel } \\
\text { visible t crane and } \\
\text { MHM operator. }\end{array}$ \\
\hline
\end{tabular}


Table 4-1. Canister Storage Building Hazard Analysis Table (Human Error). (14 sheets)

\begin{tabular}{|c|c|c|c|c|c|}
\hline $\begin{array}{l}\text { Location/ } \\
\text { Checklist } \\
\text { entry }\end{array}$ & $\begin{array}{l}\text { Hazardous } \\
\text { Condition }\end{array}$ & $\begin{array}{l}\text { Credited } \\
\text { Prevention }\end{array}$ & $\begin{array}{l}\text { Credited } \\
\text { Mitigation }\end{array}$ & $\begin{array}{l}\text { Defense-in-depth or } \\
\text { worker safety features }\end{array}$ & $\begin{array}{l}\text { HFE/Rrg evaluation } \\
\text { addition mitigators to } \\
\text { consider }\end{array}$ \\
\hline SA-F-06 & $\begin{array}{l}\text { MCO service } \\
\text { area gas } \\
\text { bottles } \\
\text { collisions or } \\
\text { impact }\end{array}$ & & $\begin{array}{l}\text { Site maintenance } \\
\text { program prohibits } \\
\text { maintenance on the } \\
\text { bottles }\end{array}$ & $\begin{array}{l}\text { All gas bottles except } \\
\text { carbon dioxide fire } \\
\text { extinguisher bottles have } \\
\text { orifices that restrict the } \\
\text { velocity of exiting gas. }\end{array}$ & $\begin{array}{l}\text { Conduct routine visual } \\
\text { inspection of bottles. } \\
\text { Chain down stored } \\
\text { bottles. } \\
\text { Limit number of bottles } \\
\text { on the floor. }\end{array}$ \\
\hline SA-F-07a & $\begin{array}{l}\text { 5-Ton gantry } \\
\text { or service area } \\
\text { collision }\end{array}$ & . & & $\begin{array}{l}\text { The S-ton gantry crane } \\
\text { and service area enclosure } \\
\text { have a limited movement } \\
\text { area. They operate inside } \\
\text { the span of both the } \\
\text { MriM and the receiving } \\
\text { crane. } \\
\text { The S-ton gantry crane is } \\
\text { limited to relatively slow } \\
\text { movement, and the } \\
\text { service area enclosure is } \\
\text { moved manually. } \\
\text { The crane and service } \\
\text { area enclosure have been } \\
\text { designed to preclude } \\
\text { tipping. } \\
\text { Personnel are trained to } \\
\text { operate the 5-ton gantry } \\
\text { and service area enclosure } \\
\text { according to facility- } \\
\text { specific procectures, which } \\
\text { include related activities } \\
\text { such as ensuring } \\
\text { equipment is not blocking } \\
\text { gantry crane and service } \\
\text { area enclosure movement. }\end{array}$ & $\begin{array}{l}\text { Provide a socond person } \\
\text { to watch for possible } \\
\text { collision opportunities } \\
\text { while equipment is } \\
\text { moving. } \\
\text { Proximity wire around } \\
\text { the 5-ton crane. }\end{array}$ \\
\hline
\end{tabular}


Table 4-1. Canister Storage Building Hazard Analysis Table (Human Error). (14 sheets)

\begin{tabular}{|c|c|c|c|c|c|}
\hline $\begin{array}{l}\text { Location } \\
\text { Checklist } \\
\text { entry }\end{array}$ & $\begin{array}{l}\text { Hazandous } \\
\text { Condition }\end{array}$ & $\begin{array}{l}\text { Credited } \\
\text { Prevention }\end{array}$ & $\begin{array}{l}\text { Credited } \\
\text { Mitigation }\end{array}$ & $\begin{array}{l}\text { Defense-in-depth or } \\
\text { worker safety features }\end{array}$ & $\begin{array}{l}\text { HFE/Erg evaluation } \\
\text { addition mitigators to } \\
\text { consider }\end{array}$ \\
\hline SA-F-07b & $\begin{array}{l}\text { MHM } \\
\text { collision or } \\
\text { rotating MHM } \\
\text { turret creates } \\
\text { a shear force } \\
\text { on the } \\
\text { supporting } \\
\text { lifting cable } \\
\text { and pneumatic } \\
\text { lines of the } \\
\text { MHM }\end{array}$ & . & . & 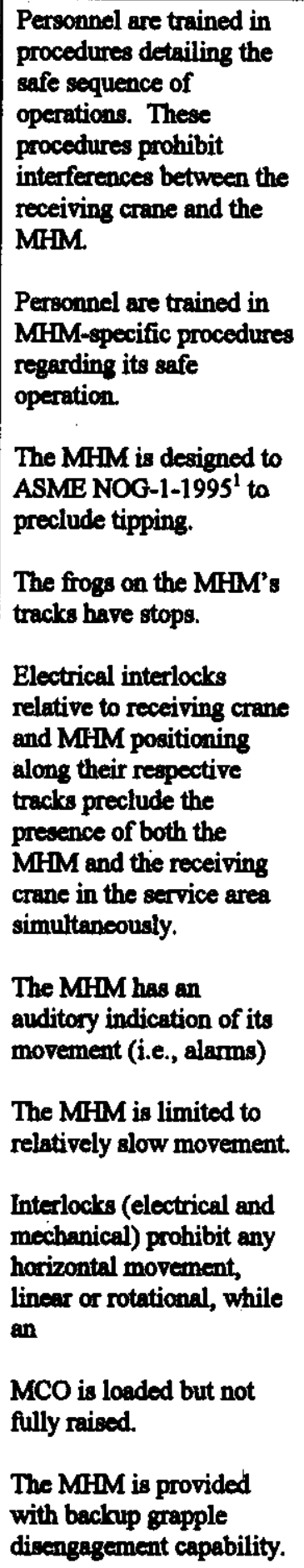 & $\begin{array}{l}\text { Ensure the alarms for } \\
\text { each of MHM and } \\
\text { receiving crane are } \\
\text { distinguishable. } \\
\text { Provide a second person } \\
\text { on the floor to view } \\
\text { status of the MCO and } \\
\text { feedback to the MHM } \\
\text { operator. } \\
\text { Additional visibility of } \\
\text { the MCO and lines } \\
\text { provided to the MHM } \\
\text { operator during } \\
\text { movement. } \\
\text { Provide a second person } \\
\text { on the floor to watch for } \\
\text { possible collisions. } \\
\text { Proximity wires around } \\
\text { the receiving crane and } \\
\text { the MHM to } \\
\text { automatically stop } \\
\text { horizontal movement. } \\
\text { Rail frog designed to } \\
\text { preclude inappropriate } \\
\text { positioning. } \\
\text { Rail frog position } \\
\text { indicator lights or panel } \\
\text { visible to crane and } \\
\text { MHM operator. } \\
\text { ming }\end{array}$ \\
\hline
\end{tabular}


Table 4-1. Canister Storage Building Hazard Analysis Table (Human Error). (14 sheets)

\begin{tabular}{|c|c|c|c|c|c|}
\hline $\begin{array}{l}\text { Location/ } \\
\text { Checklist } \\
\text { entry }\end{array}$ & $\begin{array}{l}\text { Hazardous } \\
\text { Condition }\end{array}$ & $\begin{array}{l}\text { Credited } \\
\text { Prevention }\end{array}$ & $\begin{array}{l}\text { Credited } \\
\text { Mitigation }\end{array}$ & $\begin{array}{l}\text { Defense-in-depth or } \\
\text { worker safety features }\end{array}$ & $\begin{array}{l}\text { HFE/Erg evaluation } \\
\text { addition mitigators to } \\
\text { consider }\end{array}$ \\
\hline & & & & $\begin{array}{l}\text { The MHM resolver } \\
\text { indicates the MCO's } \\
\text { relative position within } \\
\text { the service station pit } \\
\text { and/or MHM while it is } \\
\text { being raised. }\end{array}$ & \\
\hline SA-G-03a & $\begin{array}{l}\text { Drop of the } \\
\text { transportation } \\
\text { cask, a drop of } \\
\text { the MCO from } \\
\text { the MHM as } \\
\text { it is being } \\
\text { raised, a drop } \\
\text { of the cask lid, } \\
\text { or a shield } \\
\text { plug or impact } \\
\text { absorber at } \\
\text { the exchange } \\
\text { pit, or MCO } \\
\text { dropped back } \\
\text { into cask or } \\
\text { conto the cask } \\
\text { rim by the } \\
\text { MHM }\end{array}$ & $\begin{array}{l}\text { MHM } \\
\text { interlocks } \\
\text { prevent travel } \\
\text { over the } \\
\text { maintenance } \\
\text { pit and FFTF } \\
\text { pit when } \\
\text { carying an } \\
\text { MCO. } \\
\text { Interlocks are } \\
\text { protected by } \\
\text { TSRs. }\end{array}$ & $\begin{array}{l}\text { MHM interlocks } \\
\text { prevent travel over } \\
\text { the maintenance } \\
\text { pit and FFTF pit } \\
\text { when carrying an } \\
\text { MCO. Interlocks } \\
\text { are protected by } \\
\text { TSRs. }\end{array}$ & $\begin{array}{l}\text { The MHM grapple is } \\
\text { designed such that it } \\
\text { cannot release while a } \\
\text { load is being suspended } \\
\text { from it. } \\
\text { Personnel are trained to } \\
\text { facility-specific } \\
\text { procedures in the proper } \\
\text { handling of the } \\
\text { transportation cask, MCO, } \\
\text { receiving crane, gantry, } \\
\text { and MHM. }\end{array}$ & $\begin{array}{l}\text { Recertifying MHM } \\
\text { operators. } \\
\text { Insure yoke design } \\
\text { preclude human error } \\
\text { during rigging. }\end{array}$ \\
\hline SA-G-03b & $\begin{array}{l}\text { Drop of cask } \\
\text { with MCO } \\
\text { into } \\
\text { maintenance } \\
\text { pit or FFTF } \\
\text { pit. }\end{array}$ & $\begin{array}{l}\text { MHM } \\
\text { interlocks } \\
\text { prevent travel } \\
\text { over the } \\
\text { maintenance } \\
\text { pit and FFTF } \\
\text { pit when } \\
\text { carrying an } \\
\text { MCO. } \\
\text { Interlocks are } \\
\text { protected by } \\
\text { TSRs. }\end{array}$ & $\begin{array}{l}\text { MHM interlocks } \\
\text { prevent travel over } \\
\text { the maintenance } \\
\text { pit and FFTF pit } \\
\text { when carrying an } \\
\text { MCO. Interlocks } \\
\text { are protected by } \\
\text { TSRs. }\end{array}$ & $\begin{array}{l}\text { The MHM grapple is } \\
\text { designed such that it } \\
\text { cannot be released while a } \\
\text { load is being suspended } \\
\text { from it. } \\
\text { Personnel are trained to } \\
\text { facility-specific } \\
\text { procedures in the proper } \\
\text { handling of the } \\
\text { transportation cask, MCO, } \\
\text { receiving crane, gantry, } \\
\text { and MHM. }\end{array}$ & $\begin{array}{l}\text { Recertifying MHM } \\
\text { operators. }\end{array}$ \\
\hline
\end{tabular}


Table 4-1. Canister Storage Building Hazard Analysis Table (Human Error). (14 sheets)

\begin{tabular}{|c|c|c|c|c|c|}
\hline $\begin{array}{l}\text { Location/ } \\
\text { Checklist } \\
\text { entry }\end{array}$ & $\begin{array}{l}\text { Hazandous } \\
\text { Condition }\end{array}$ & $\begin{array}{l}\text { Credited } \\
\text { Prevention }\end{array}$ & $\begin{array}{l}\text { Credited } \\
\text { Mitigation }\end{array}$ & $\begin{array}{l}\text { Defense-in-depth or } \\
\text { worker safety features }\end{array}$ & $\begin{array}{l}\text { HFE/Erg evaluation } \\
\text { addition mitigators to } \\
\text { consider }\end{array}$ \\
\hline $\begin{array}{l}\text { CSB OA- } \\
\text { E-07 }\end{array}$ & $\begin{array}{l}\text { Rotating } \\
\text { MHM turret } \\
\text { creates a shear } \\
\text { force on the } \\
\text { supporting } \\
\text { lifting cable } \\
\text { and pneumatic } \\
\text { lines of the } \\
\text { MHM }\end{array}$ & & & $\begin{array}{l}\text { Interlocks (electrical and } \\
\text { mechanical) prohibit any } \\
\text { horizontal movement, } \\
\text { linear or rotational, while } \\
\text { an MCO is loaded but not } \\
\text { fully raised. } \\
\text { MHM resolver indicates } \\
\text { MCO's relative position } \\
\text { within the storage tube } \\
\text { and/or MHM while it is } \\
\text { being lowered or raised. } \\
\text { The MHM is provided } \\
\text { with a backup grapple } \\
\text { disengagernent capability. } \\
\text { The MHM-tube plug } \\
\text { interface provides active } \\
\text { ventilation. } \\
\text { Personnel are trained to } \\
\text { MHM-specific procedures } \\
\text { for safe operation. }\end{array}$ & $\begin{array}{l}\text { Provide a second } \\
\text { person on the floor to } \\
\text { view the status of the } \\
\text { MCO and feedback to } \\
\text { the MHM operator. } \\
\text { Additional visibility } \\
\text { of the MCO and lines } \\
\text { provided to the MHM } \\
\text { operator during } \\
\text { movement. }\end{array}$ \\
\hline $\begin{array}{l}\text { CSB OA- } \\
\text { F-7 }\end{array}$ & $\begin{array}{l}\text { MHM impact. } \\
\text { Rotating } \\
\text { MHM turret } \\
\text { creates a shear } \\
\text { force on the } \\
\text { supporting } \\
\text { lifting cable } \\
\text { and pneumatic } \\
\text { lines of the } \\
\text { MHM }\end{array}$ & . & & $\begin{array}{l}\text { The MHM is designed to } \\
\text { ASME NOG-1-1995 to } \\
\text { preclude tipping. } \\
\text { The rail frogs on the } \\
\text { MHM's tracks have } \\
\text { electrical and mechanical } \\
\text { stops. } \\
\text { Electrical interlocks } \\
\text { relative to receiving crane } \\
\text { and MHM positioning } \\
\text { along their respective } \\
\text { tracks preclude the } \\
\text { presence of both the } \\
\text { MHM and the receiving } \\
\text { crane in the service area } \\
\text { simultaneously. } \\
\text { The MHM has an } \\
\text { auditory indication of its } \\
\text { movernent (i.e., alarms). } \\
\text { The MHM has a collision } \\
\text { avoidance system that } \\
\text { detects obstacles to its } \\
\text { movernent. }\end{array}$ & $\begin{array}{l}\text { Provide a second } \\
\text { person on the floor to } \\
\text { view the status of the } \\
\text { MCO and feedback to } \\
\text { the MHM operator. } \\
\text { Additional visibility } \\
\text { of the MCO and lines } \\
\text { provided to the MHM } \\
\text { operator during } \\
\text { movement. }\end{array}$ \\
\hline
\end{tabular}


Table 4-1. Canister Storage Building Hazard Analysis Table (Human Error). (14 sheets)

\begin{tabular}{|c|c|c|c|c|c|}
\hline $\begin{array}{c}\text { Location/ } \\
\text { Checklist } \\
\text { entry }\end{array}$ & $\begin{array}{l}\text { Hazardous } \\
\text { Condition }\end{array}$ & $\begin{array}{l}\text { Credited } \\
\text { Prevention }\end{array}$ & $\begin{array}{l}\text { Credited } \\
\text { Mitigation }\end{array}$ & $\begin{array}{l}\text { Defense-in-depth or } \\
\text { worker safety features }\end{array}$ & $\begin{array}{l}\text { HFE/Brg evaluation } \\
\text { addition mitigators to } \\
\text { consider }\end{array}$ \\
\hline & & ' & $r$ & $\begin{array}{l}\text { Interlocks (electrical and } \\
\text { mechanical) prohibit any } \\
\text { horizontal movement, } \\
\text { linear or rotational, while } \\
\text { an MCO is loaded but not } \\
\text { fully raised. } \\
\text { MHM resolver indicates } \\
\text { MCO's relative position } \\
\text { within the storage tube } \\
\text { and/or MHM while it is } \\
\text { being lowered or raised. } \\
\text { The MrM is provided } \\
\text { with a backup grapple } \\
\text { disengagement capability. } \\
\text { Personnel are trained to } \\
\text { procedures detailing the } \\
\text { safe sequence of } \\
\text { operations. These } \\
\text { procedures prohibit } \\
\text { interferences between the } \\
\text { receiving crane and the } \\
\text { MHM. }\end{array}$ & . \\
\hline $\begin{array}{l}\text { CSB OA- } \\
\text { G-03; and } \\
\text { OAG-13 }\end{array}$ & $\begin{array}{l}\text { Dropped } \\
\text { MCO impacts } \\
\text { MHM } \\
\text { turntable. } \\
\text { Top and sides } \\
\text { of standard } \\
\text { storage tube. } \\
\text { Bottom of } \\
\text { standard } \\
\text { storage tube if } \\
\text { impact } \\
\text { absorber not } \\
\text { present. } \\
\text { Other MCO in } \\
\text { the storage } \\
\text { tube. }\end{array}$ & r & $\cdot$ & $\begin{array}{l}\text { Inpact absorbers are } \\
\text { placed in intermediate } \\
\text { positions. } \\
\text { The MHM grapple is } \\
\text { designed such that it } \\
\text { cannot be released while a } \\
\text { load is being suspended } \\
\text { from it. } \\
\text { Personnel are trained to } \\
\text { facility-specific } \\
\text { procedures in the proper } \\
\text { handling of the } \\
\text { transportation cask, MCO, } \\
\text { receiving crane, and } \\
\text { MHM. } \\
\text { Lifting devices used at the } \\
\text { CSB are designed to } \\
\text { handle the loads they will } \\
\text { carry. }\end{array}$ & $\begin{array}{l}\text { Recertifying MHM } \\
\text { operators }\end{array}$ \\
\hline
\end{tabular}


Table 4-1. Canister Storage Building Hazard Analysis Table (Human Error). (14 sheets)

\begin{tabular}{|c|c|c|c|c|c|}
\hline $\begin{array}{c}\text { Location/ } \\
\text { Checklist } \\
\text { entry }\end{array}$ & $\begin{array}{l}\text { Hazardous } \\
\text { Condition }\end{array}$ & $\begin{array}{l}\text { Credited } \\
\text { Prevention }\end{array}$ & $\begin{array}{l}\text { Crodited } \\
\text { Mitigation }\end{array}$ & $\begin{array}{l}\text { Defense-in-depth or } \\
\text { worker safety features }\end{array}$ & $\begin{array}{l}\text { HFE/Erg evaluation } \\
\text { addition mitigators to } \\
\text { consider }\end{array}$ \\
\hline $\begin{array}{l}\text { CSB OA- } \\
\text { G-14 }\end{array}$ & $\begin{array}{l}\text { Drop of } \\
\text { standard tube } \\
\text { plug, impact } \\
\text { absorber, } \\
\text { cover plate } \\
\text { assembly, seal } \\
\text { ring, or } \\
\text { rigging } \\
\text { equipment, or } \\
\text { MCO }\end{array}$ & & . & $\begin{array}{l}\text { Impact absorbers are } \\
\text { placed in intermediate } \\
\text { positions. } \\
\text { The MHM grapple is } \\
\text { designed such that it } \\
\text { cannot be released while a } \\
\text { load is being suspended } \\
\text { from it. } \\
\text { Personnel are trained to } \\
\text { facility-specific } \\
\text { procedures in the proper } \\
\text { handling of the } \\
\text { transportation cask, MCO, } \\
\text { receiving crane, and } \\
\text { MHM. } \\
\text { Lifting devices used at the } \\
\text { CSB are designed to } \\
\text { handle the loads they will } \\
\text { carry. }\end{array}$ & $\begin{array}{l}\text { Recertifying MHM } \\
\text { operators }\end{array}$ \\
\hline $\begin{array}{l}\text { Weld } \\
\text { Station } \\
\text { WS-B-05 }\end{array}$ & $\begin{array}{l}\text { Localized } \\
\text { overheating } \\
\text { and burn } \\
\text { through an } \\
\text { MCO }\end{array}$ & & . & $\begin{array}{l}\text { Welder arrangements } \\
\text { makes misalignments } \\
\text { unlikely. } \\
\text { The MCO and pit can be } \\
\text { built to replicate the } \\
\text { MCO-shielding } \\
\text { arrangement. } \\
\text { MHM grapple design } \\
\text { reduces the likelihood of } \\
\text { MCO release in an } \\
\text { incorrect position. } \\
\text { Shield mass provides a } \\
\text { limited heat sink. } \\
\text { The welder alignment is } \\
\text { checked before welding. } \\
\text { Multiple checks of the } \\
\text { weld are made between } \\
\text { passes. } \\
\text { Operators are trained and } \\
\text { qualified to follow proper } \\
\text { procedures in the proper } \\
\text { observation of welding } \\
\text { activities. }\end{array}$ & $\begin{array}{l}\text { Thermocouples or } \\
\text { infrared devices to } \\
\text { register MCO skin } \\
\text { temperatures and alarm } \\
\text { to the operator. }\end{array}$ \\
\hline
\end{tabular}


Table 4-1. Canister Storage Building Hazard Analysis Table (Human Error). (14 sheets)

\begin{tabular}{|c|c|c|c|c|c|}
\hline $\begin{array}{l}\text { Location/ } \\
\text { Checklist } \\
\text { entry }\end{array}$ & $\begin{array}{l}\text { Hazardous } \\
\text { Condition }\end{array}$ & $\begin{array}{l}\text { Credited } \\
\text { Prevention }\end{array}$ & $\begin{array}{l}\text { Credited } \\
\text { Mitigation }\end{array}$ & $\begin{array}{l}\text { Defenso-in-depth or } \\
\text { worker safety features }\end{array}$ & $\begin{array}{l}\text { HFE/Brg evaluation } \\
\text { addition mitigators to } \\
\text { consider }\end{array}$ \\
\hline WS-E-07 & $\begin{array}{l}\text { Rotating } \\
\text { MHM turret } \\
\text { creates a shear } \\
\text { force on the } \\
\text { supporting } \\
\text { lifting cable } \\
\text { and pneumatic } \\
\text { lines of the } \\
\text { MHM }\end{array}$ & & & $\begin{array}{l}\text { MHM resolver indicates } \\
\text { MCO's relative position } \\
\text { within the storage } \\
\text { sampling/weld station } \\
\text { and/or MHM while it is } \\
\text { being lowered or raised. } \\
\text { The MHM is provided } \\
\text { with a backup grapple } \\
\text { disengagement capability. } \\
\text { The MHM-sampling/weld } \\
\text { interface provides active } \\
\text { ventilation. } \\
\text { Personnel are trained to } \\
\text { MHM-specific procedures } \\
\text { for safe operation. }\end{array}$ & $\begin{array}{l}\text { Provide a second person } \\
\text { on the floor to view the } \\
\text { status of the MCO and } \\
\text { feodbeck to the MHM } \\
\text { operator. } \\
\text { Additional visibility of } \\
\text { the MCO and lines } \\
\text { provided to the MHM } \\
\text { operator during } \\
\text { movement. }\end{array}$ \\
\hline $\begin{array}{l}\text { WS-F-02, } \\
\text { and WS- } \\
\text { F-05 }\end{array}$ & $\begin{array}{l}\text { Inadvertent } \\
\text { crane } \\
\text { movement }\end{array}$ & & & . & $\begin{array}{l}\text { Removable stoel "cage" } \\
\text { around sampling area to } \\
\text { prevent other equipment } \\
\text { from insdvertently } \\
\text { impacting the lines. } \\
\text { Personnel training and } \\
\text { following proper } \\
\text { procedures. } \\
\text { Use a second person to } \\
\text { verify crane movement } \\
\text { and line status. }\end{array}$ \\
\hline WS-F-06 & $\begin{array}{l}\text { Helium } \\
\text { cylinders, } \\
\text { become } \\
\text { "missiles" and } \\
\text { impact. }\end{array}$ & & $\begin{array}{l}\text { Site maintenance } \\
\text { program prahibits } \\
\text { maintenance on the } \\
\text { bottles }\end{array}$ & $\begin{array}{l}\text { All gas bottles except } \\
\text { carbon dioxide fire } \\
\text { extinguisher bottles have } \\
\text { orifices that restrict the } \\
\text { velocity of exiting gas. }\end{array}$ & $\begin{array}{l}\text { Conduct routine visual } \\
\text { inspection of bottles. } \\
\text { Chain down stored } \\
\text { bottles. } \\
\text { Limit number of bottles } \\
\text { on the floor. }\end{array}$ \\
\hline
\end{tabular}


Table 4-1. Canister Storage Building Hazard Analysis Table (Human Error). (14 sheets)

\begin{tabular}{|c|c|c|c|c|c|}
\hline $\begin{array}{l}\text { Location/ } \\
\text { Checklist } \\
\text { entry }\end{array}$ & $\begin{array}{l}\text { Hazardous } \\
\text { Condition }\end{array}$ & $\begin{array}{l}\text { Credited } \\
\text { Prevention }\end{array}$ & $\begin{array}{l}\text { Credited } \\
\text { Mitigation }\end{array}$ & $\begin{array}{l}\text { Defense-in-depth or } \\
\text { worker safety features }\end{array}$ & $\begin{array}{l}\text { HFE/Erg evaluation } \\
\text { addition mitigators to } \\
\text { consider }\end{array}$ \\
\hline WS-F-07 & $\begin{array}{l}\text { MHM } \\
\text { collision } \\
\text { Rotating } \\
\text { MHM turret } \\
\text { creates a shear } \\
\text { force on the } \\
\text { supporting } \\
\text { lifting cable } \\
\text { and pneumatic } \\
\text { lines of the } \\
\text { MHM }\end{array}$ & . & . & $\begin{array}{l}\text { The MHM has an } \\
\text { auditory indication of its } \\
\text { movement (i.e., alarms). } \\
\text { The MHM has a collision } \\
\text { avoidance system that } \\
\text { detects obstacles to its } \\
\text { movement. } \\
\text { MHM is limited to } \\
\text { relatively slow movement. } \\
\text { MHM resolver indicates } \\
\text { MCO's relative position } \\
\text { within the sample/weld } \\
\text { station and/or MHM } \\
\text { while it is being lowered } \\
\text { or raised. } \\
\text { The MHM is provided } \\
\text { with a backup grapple } \\
\text { disengagement capability. } \\
\text { Personnel are trained to } \\
\text { procedures detailing the } \\
\text { safe sequence of } \\
\text { operations. These } \\
\text { procectures prohibit } \\
\text { interferences between the } \\
\text { receiving crane and the } \\
\text { MHM. } \\
\text { Personnel are trained in } \\
\text { MHM-specific procedures } \\
\text { for safe operation. }\end{array}$ & $\begin{array}{l}\text { Provide a second person } \\
\text { on the floor to view the } \\
\text { status of the MCO and } \\
\text { feedback to the MHM } \\
\text { operator. } \\
\text { Additional visibility of } \\
\text { the MCO and lines } \\
\text { provided to the MHM } \\
\text { operator during } \\
\text { movement. }\end{array}$ \\
\hline WS-G0-3a & $\begin{array}{l}\text { Dropped } \\
\text { MCO from the } \\
\text { MHM as it is } \\
\text { being raised. }\end{array}$ & & 4 & $\begin{array}{l}\text { The MHM grapple is } \\
\text { designed such that it } \\
\text { cannot release while a } \\
\text { loed is being suspended } \\
\text { from it. } \\
\text { Personnel are trained to } \\
\text { facility-specific } \\
\text { procedures in the proper } \\
\text { handling of MCOs and } \\
\text { MHM. }\end{array}$ & $\begin{array}{l}\text { Chains or other passive } \\
\text { means of preventing the } \\
\text { sampling equipment } \\
\text { from falling onto the } \\
\text { MCO while the cover is } \\
\text { removed. } \\
\text { Second perwon on the } \\
\text { floor to view status of } \\
\text { the MCO and feedback } \\
\text { to the MHM operator. } \\
\text { Additional visibility of } \\
\text { the MCO and lines } \\
\text { providod to the MHM } \\
\text { operator during } \\
\text { movement. }\end{array}$ \\
\hline
\end{tabular}


Table 4-1. Canister Storage Building Hazard Analysis Table (Human Error). (14 sheets)

\begin{tabular}{|c|c|c|c|c|c|}
\hline $\begin{array}{c}\text { Location/ } \\
\text { Checklist } \\
\text { entry }\end{array}$ & $\begin{array}{l}\text { Hazardous } \\
\text { Condition }\end{array}$ & $\begin{array}{l}\text { Credited } \\
\text { Prevention }\end{array}$ & $\begin{array}{l}\text { Credited } \\
\text { Mitipation }\end{array}$ & $\begin{array}{l}\text { Defense-in-depth or } \\
\text { worker safety features }\end{array}$ & $\begin{array}{l}\text { HFE/Erg evaluation } \\
\text { addition mitigators to } \\
\text { consider }\end{array}$ \\
\hline WS-03b & $\begin{array}{l}\text { Equipment } \\
\text { dropped on } \\
\text { sample line } \\
\text { Dropped } \\
\text { equipment } \\
\text { (c.g., hoods, } \\
\text { sampling } \\
\text { equipment, pit } \\
\text { covers) }\end{array}$ & & & $\begin{array}{l}\text { The sample hood is } \\
\text { designed to confine any } \\
\text { releases from the MCO } \\
\text { during sampling. } \\
\text { The sample hood has a } \\
\text { HEPA filter on its exit to } \\
\text { filter any releases to the } \\
\text { sample hood before they } \\
\text { are exhausted to the } \\
\text { HVAC system. } \\
\text { Sampling/weld station } \\
\text { gantry crane bumper } \\
\text { prevents collisions with } \\
\text { sample hood and sample } \\
\text { lines. }\end{array}$ & $\begin{array}{l}\text { Chains or other passive } \\
\text { means of preventing the } \\
\text { sampling equipment } \\
\text { from falling onto the } \\
\text { MCO while the cover is } \\
\text { removed. } \\
\text { Administratively defined } \\
\text { "clear zone" demarcated } \\
\text { on the floor. }\end{array}$ \\
\hline $\begin{array}{l}\text { Outside } \\
\text { OU-Q-04 }\end{array}$ & $\begin{array}{l}\text { Impact on the } \\
\text { CSB facility }\end{array}$ & & & $\begin{array}{l}\text { The roads near the facility } \\
\text { are designed to guide } \\
\text { vehicles around the } \\
\text { facility, rather than } \\
\text { directly toward the } \\
\text { facility, thus limiting their } \\
\text { potential to impact the } \\
\text { facility. } \\
\text { The transporter and } \\
\text { transportation cask are } \\
\text { designed to survive } \\
\text { vehicle impacts without } \\
\text { releasing radioactive or } \\
\text { toxic materials. } \\
\text { Speed limits are posted in } \\
\text { the vicinity of the CSB to } \\
\text { keep vehicles speeds low. } \\
\text { There will be no more } \\
\text { than one transporter in the } \\
\text { CSB boundary at one } \\
\text { time, reducing the } \\
\text { potential for consequences } \\
\text { involving two or more } \\
\text { transporters. }\end{array}$ & $\cdot$ \\
\hline
\end{tabular}




\section{SNF-4831 REV 0}

Table 4-1. Canister Storage Building Hazard Analysis Table (Human Error). (14 sheets)

\begin{tabular}{|l|l|l|l|l|l|}
\hline $\begin{array}{l}\text { Location/ } \\
\text { Checklist } \\
\text { entry }\end{array}$ & $\begin{array}{c}\text { Hazardous } \\
\text { Condition }\end{array}$ & $\begin{array}{c}\text { Credited } \\
\text { Prevention }\end{array}$ & $\begin{array}{c}\text { Credited } \\
\text { Mitigation }\end{array}$ & $\begin{array}{c}\text { Defense-in-depth or } \\
\text { worker safety features }\end{array}$ & $\begin{array}{l}\text { HFE/Erg evaluation } \\
\text { addition mitigators to } \\
\text { consider }\end{array}$ \\
\hline $\begin{array}{l}\text { Off- } \\
\text { Normal } \\
\text { MCO } \\
\text { Overpack } \\
\text { Storage } \\
\text { Tube }\end{array}$ & $\begin{array}{l}\text { Impacts or } \\
\text { collisions with } \\
\text { overpack } \\
\text { shield plug } \\
\text { assembly. }\end{array}$ & & & & $\begin{array}{l}\text { The MHM has a } \\
\text { collision avoidance } \\
\text { system that detects } \\
\text { obstacles to its } \\
\text { movement. }\end{array}$ \\
$\begin{array}{l}\text { CSB OA- } \\
\text { F-02 }\end{array}$ & & & & $\begin{array}{l}\text { MHM is limited to } \\
\text { relatively slow } \\
\text { movement. }\end{array}$ \\
& & & & $\begin{array}{l}\text { Position a second person } \\
\text { on floor to watch for } \\
\text { potential collisions. }\end{array}$ \\
\hline
\end{tabular}

'ASME NOG-1-1995 (1995).

$\mathrm{OA}=$ operating area

SA $=$ service area

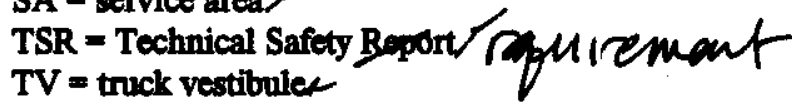

WS $=$ sampling/weld station 
This page intentionally left blank. 


\subsection{INFORMATION PROVIDED IN FLUOR DANIEL HANFORD, INC. LETTERS}

Two Fluor Daniel Hanford, Inc. letters were written concerning CSB issues. The first letter is FDH-9755210 R1, Response To Issues Associated With Fabrication Release For The Spent Nuclear Fuel Project Multi-Canister Overpack Handling Machine (Williams 1997). The second letter is FDH-9855462, Contract Number DE-AC06-96RL13200: Update Of 22 Issues From The U.S. Department of Energy, Richland Operations Office Review OfMulti-Canister Overpack Handling Machine (Mahaffey 1998).

Letter FDH-9755210 R1 (Mahaffey 1997) is a response to issues associated with fabrication release for the SNF MCM. At that time an MHM risk evaluation package was presented to the U.S. Department of Energy, Richland Operations Office to assess the status of design and risks associated with $R L$ release of remaining MHM fabrication. Item 2, of the enclosure, addresses the concern of "Implementation of a human factors program that meets the requirements of DOE Order 6430.1A and guidance contained in DB-003, item \#9 must begin immediately. This needs to include environmental factors and their interface with the Canister Storage Building (CSB)."

The response was indicated as "Complete."

"Human factors engineering programs in compliance with DOE Order 6430.1A have been included since the inception of the CSB project. Engineers procedures (see Exhibit A-1) require a Human Factors Engineering Plan and periodic human factors reviews.

The MHM specification imposes MIL-STD-1472D-89 and NUREG 700 (guidance only) on panel layout. This meets DOE STD 6430.1A Section 1300. A human factors design review checklist will be used to review the panel design. Design reviewers will include a human factors specialist, operations and an Instrumentation and Control Engineer. This review will be conducted in about 5 weeks on a panel mockup at Ederer. Any deficiencies will be noted and corrected. A compilation of control system functions is contained in the GEC Control System Specification.

There are no safety class control actions required by the operator or associated with the controls and indicating devices. Therefore, the control panel is not "important to safety" and NRC equivalency does not apply."

Discussion: The human factors review reported in SNF-3907 was completed on the MHM control console at Ederer in Seattle, Washington on November 6, 1997. The report concluded that human factors engineering was judged satisfactory based upon correction of the following items:

- Level 1 labeling required for sub-system groups 


\section{SNF-4831 REV 0}

- Level 2 labeling for alarm and status modules

- Relocation of two control switches on the crane control panel is needed for better grouping and labeling

- Application of additional color coding on the Crane Control Panel for better group identification and demarcation

- Application of vertical color line demarcation to the Alarm and Status Indicator Modules

- Units of measure noted on digital readouts located on MCO Hoist Panel.

The report also included a set of recommendations (see SNF-3907).

SNF-3907 is unclear as to the above items actually being completed or not. Was the HFE "satisfactory" because the above items were included and observed, or will the HFE be "satisfactory" once the above items are corrected? The control panel, if not properly laid out and understandable to the operator, may lead to significant human error, possibly resulting in an offnormal occurrence. The use of operators during a mock-up or simulation design of the control panel will help ensure that the MHM control panel meets the expectations of operating personnel, and any deficiency identified by the operator(s) can be reviewed and changes made for improving design.

Letter FDH-9855462 (Mahaffey1998) updated 22 issues from the DOE, Richland Operations Office review of MHM, supporting key driver resolution committee process for MHM installation. Attachment " 2 " to this letter provides closure of Issue 2, from a human factors review as follows:

"A human factors review was performed as part of the DE\&S Hanford, Inc. review of the Multi-Canister Overpack Handling Machine (MHM) control console. The reviewer was Jerry Prickett of Fluor Daniel, Inc. who accompanied operations and engineering personnel. The following is the closure of specific comments identified by DOE':

\section{System Grouping}

As a result of deleting the inerting systems, significant changes were made to the control console layout including clearly grouping controls and indicator lights by system. The changes implement and improve on the recommendations resulting from the Human Factors Evaluation.

\section{System/Group Demarcation}

Color-coding by system was added. Different colors are now provided for each of the systems/groups. 


\section{SNR-4831 REV 0}

\section{Hierarchical Labeling}

Larger Level 1 legend plates were added for each system/group.

\section{Alarm Anmunciators/Status Modules}

Suggested Level 2 legend will be added to the status module. The groupings on the alarm module do not provide a reasonable means to include Level 2 legends. The design and operating philosophy is such that none of the alarm lights are illuminated during normal operations [sic]. If a parameter goes into an alarm state, an audible alarm will sound. This will prompt the operator to look at the alarm panel to determine and acknowledge the alarm. Level 2 legends will not provide added value in this situation.

\section{Issue of interface between operator and cathode ray tube}

There is no issue of communications between the operators and the cathode-ray tube interface. The cathode ray tube is used to monitor final alignment of the MHM with a storage tube. The operator watches the electronically generated cross-hairs on the cathode ray tube for alignment with targets on the top of the plug, receiving station or weld/sampling station during movements of the MHM bridge and trolley."

Recommendation from this evaluation: This reviewer is not satisfied with the information as it appears in the above letters. It is highly recommended that the control panel(s) be further evaluated at test and evaluation using recommended HFE checklist for this purpose. Training and procedure are influenced and dependent on appropriate design of the control panels. Therefore, the control panels should continue to receive appropriate engineering work. Even though it was stated that the control panel is not "important-to-safety," this reviewer believes it is safety significant. 


\section{SNF-4831 REV 0}

This page intentionally left blank. 


\subsection{HUMAN FACTORS ENGINEERING/ERGONOMIC EVALUATION}

The CSB facility structures and support structures have been designed and are in place. A few items of equipment or tools are undergoing engineering or re-engineering, as will be. described below. An overview assessment of the HFE work accomplished to date shows a very high degree of consideration for human-machine interfacing. For example, where possible, machines are doing the work of lifting and carrying items of significant weight. The CSB will be operating with a minimum crew (see HNF-SD-SNF-PD-011) and Appendix A, Operational Sequence Block Flow Diagram Overview, shows the typical tasking that will be accomplished during CSB production.

The purpose for going through the SSCs in the beginning of this report was to show just how minimal human-machine interaction is, with regard to the entire facility as a whole. The graded approach method presented at the beginning also indicated many systems will not have human interaction, other than possibly routine or periodic maintenance. Outside of the major items of equipment, for example, the receiving crane and MHM, much of human activity will be involved with sampling, recording data, routine maintenance activities as described in the SDDs, security, communications, and housekeeping, etc. There are a number of critical areas where human-machine interfacing occurs, most notable is operator control of the MHM or receiving crane. The CSB process is not a fast process, such as an assembly line, but a slow deliberate process, with lengthy process time between the major actions.

Ergonomically, a few concerns arise because of tooling versus ALARA requirements. Biomechanical forces in handling some of the tooling may be a limiting factor for whoever is able to actually accomplish the task. For example, long reach tools will require substantially more force to hold and operate. Long reaches may be a problem and may also quantify the size (anthropometrically speaking) of the person who does the work. It is generally known in Human Factors work that a female must exert $15 \%$ more force to accomplish some types of work, than a male, because of different skeletal structures and force coupling arrangements. Therefore, attention should be paid to whom is assigned to handle some of the manual labor tasks.

Where appropriate, designs will inchude HFE inputs or engineering will implement administrative features to meet the intent of the HFE checklists. For example, if there is a biomechanical disadvantage created in the design, because of ALARA requirements, then an engineering change will first be sought to overcome the disadvantage, taking into account factors such as cost of change, time required to redesign based on project schedule, etc. When the engineering change is not feasible, because of project factors, then administrative controls will be put into place, for example, certification of operator capability to perform the task, training before performance of the task, etc.

In other areas of ergonomics concern, are the layout of the controls on the receiving crane. The grip controls appear misplaced geometrically for proper grasping. The design of the hand controls will introduce significant radial or ulnar deviations in the operator's hands and wrists, or problems with pronation or supination of the hands, depending on how the controls are 
used. These concerns are in addition to the already noted safety concern of possibly bumping into the controls because they are protruding into the worker's operating space.

The current design for cask servicing operations put the operators at a biomechanical disadvantage with the proposed work method of leaning over while working on the knees; or with extended reaches (arm proposed as completely outstretched). The cask servicing operation should continue to be monitored and followed-up in design to ensure the best possible conditions for manual work are achieved, factoring in costs, time spent in these operations, and other factors.

The control room in the Support Building appears to incorporate adjustable furnishings, base on a tour of the facility. Attention should be given to chair design, as well. It is anticipated the environmental design (e.g., illumination, HVAC, noise, and aesthetics) will easily meet the requirements of DOE STD 6430.1A Section 1300.

A potential safety problem was discovered at the receiving crane, while touring the facility. It was observed that the operator or maintainer could easily bump their head against a structure protruding out into the working platform area. When working under this structure, attending to an electrical panel to the right side of the control station area, the maintainer's head could hit the protruding structure when standing up. A recommendation to mitigate this problem, would be to make this structure readily visible with safety markings, add insulating material to the edges and corner of the protruding structure and brief the operators in training about this potential hazard.

Human Factors Engineering work should continue on the system not completely designed or in some cases, not yet conceptualized. For example, two tools will need to be acquired or design to maneuver the rail frogs. The rail frogs will need manual unbolting from their place in the track, lifting (weight is approximately $700 \mathrm{lb}$ each), and rotating to realign the track to the appropriate machine (receiving crane or MHM).

The HVAC, GEMS, instrument air/service air and other systems such as these will have mainly routine maintenance performed on them, or will be interfaced infrequently. Therefore, attention should focus on the accessibility of HEPA filter changeouts, instrument accessibility for calibrations, and remove and replacement of failed components. Maintainability is the human engineering key to these systems.

\subsection{STAFFING PLAN}

The purpose of the CSB staffing plan is to provide a baseline for process operations staffing needs. It provides definition of the staffing level needed to support the CSB processing facility and the transition to that staffing level. Transitional staffing reflects personnel needed to support staffing, procedure development, training module development, training, proof of proficiency, and readiness during the management self assessment and operational readiness review process, and production process startup. 


\section{SNF-4831 REV 0}

\subsubsection{Stafing Key Operational Assumptions for the Canister Storage Building}

Staffing numbers are based on a number of key assumptions. These key assumptions include those required preceding process operations and those required during process operations. These key assumptions are augmented by facility/process specific assumptions.

The operational assumptions for CSB are as follows:

- The CSB facility will have the capability to operate 24 hours per day, seven days per week

- There will be one service pit in the CSB for the cask-MCO

- An MCO sample station will be provided for testing of the validation MCOs

- Weld stations will be provided for seal welding conditioned MCOs

- Waste will be shipped from the CSB to the solid waste facility

- Load out area for waste will be available

- Individual exposure will not exceed 1000 mrem per year

- MCOs will be shipped any time (24 hours per day)

- $\quad$ Average rate of four MCOs will be shipped per week from the CVDF during concurrent operation of K West and $\mathrm{K}$ East Basins (based on a 72-hour process time)

- Radiological control equipment/monitors will be in place and available

- Training will be continuous

- Lunchroom and restroom facilities will be located in MO-46 (Support Building), adjacent to the CSB

- Existing minimum safe staffing will be maintained.

\subsubsection{Stafing Resources}

The work scope, production throughput, and work schedule bind the resources required for CSB facility operation over the life of the SNF Project. The necessary resources are based on the following:

- Work Scope: move 2100 metric tons uranium (MTUs), spent nuclear fuel, from wet storage in the $\mathrm{K}$ Basins to dry storage in the CSB 


\section{SNF-4831 REV 0}

- Production Throughput: average rate of four MCOs per week from the CVDF during concurrent operation of $K$ East and $K$ West Basins

- Work Schedule: complete fuel movement in three years, one month.

The plan defines the resources needed to support and maintain CSB facility operations on a 24-hour per day, seven days per week schedule.

To minimize operator radiation dose, the CSB facility sub-project has been provided with a radiation dose target for their activity. The target was designed to keep radiation doses ALARA.

The staffing operational concept is based on shared resources between SNF Project facilities. It utilizes functional work groups for equalizing exposure, sharing of resources during down times, and sharing of maintenance resources.

Using personnel in more than one facility/process will result in increased training requirements for some individuals.

The startup of fuel removal activities from the $\mathrm{K}$ Basins will be time phased to facilitate personnel hiring and training. The CSB will be ready to accept fuel from the basins at startup.

\subsubsection{Current Stafining Recommendation}

The SNF Project processing organization will consist of multidisciplined teams with welldefined work scopes. The team concept will facilitate communication and joint problem resolution while focusing on processing goals.

The selection of staff to support transition to an operational processing organization is in its early stages. Some interviews have been completed. The functional transition to a processing organization will continue through the first months of operation. this includes:

The CSB process support crews will be responsible for all facility operations in the CSB;

- Staging, storing, and monitoring of $\mathrm{MCO}$

- Controlling locks and tags

- Controlling facility access

- Providing contamination and radiation control

- Handling laundry

- Operating systems 


\section{SNF-4831 REV 0}

- Controlling radiation area access

- Maintaining radiological control routines

- Supporting radiological work area control as needed

- Supporting seal welding of MCOs.

Staffing for each shift will include 5 operators and 3 HPTs for a total of 25 operators and 15 HPTs.

Maintenance response crews will be responsible for on-shift maintenance repairs to support continued production operations. This includes the CSB. Staffing for each shift will include:

- Two electricians

- One millwright

- One pipefitter

- One instrument technician

- One driver

- One engineer.

The CSB will have a facility manager and an exempt support person on each shift. Each facility manager and exempt support people will be certified on their facility. This also provides a "defense in depth" concept by providing certified exempt support people on each shift, to assist and fill in for the facility manager when required. The facility managers will be experienced managers who can fill in for the shift operations manager, when required.

Support people will be at the disposal of the shift operations manager to enhance continued operations. These people will include a travelling crew to supplement facility production needs; a multi-craft maintenance response crew to allow on-shift repair work; process engineering support to oversee CSB facility production processes; and health physics and lab support personnel to maintain the radiological health of the facilities and to provide sample analysis capability. These people will supplement and support the facility operations crew and will report to the shift operations manager.

A normal 8-hour shift is being planned at this time, with provision for a second shift if necessary. The activity job hazard/safety analysis and prejob meetings provide the operators information to help them identify and control or mitigate hazards. CSB administrative procedures will require job hazard analyses as part of the job planning. Monthly, quarterly, and yearly safety inspections are conducted to identify unsafe conditions throughout the facility, including CSB 
equipment. Unsafe conditions will result in postings, personnel protective equipment requirements, and timely corrective actions, as appropriate.

The complete operational staffing plan is found in HNF-SD-SNF-PD-011, Rev 2, Spent Nuclear Fuel Project Operational Staffing Plan. Any TSR will also provide for the appropriate staffing with a basis and a qualification requirement. Chapter 3.0 of the CSB SAR HNF-3553 provides the necessary TSR(s) information.

\subsection{PROCEDURES}

A review of PROC-DI-001-01, SNF Project Technical Procedure Writer's Guide, demonstrates that the SNF Project meets the technical procedure writing requirements of DOE Order 5480.19, Conduct of Operations Requirements for Department of Energy Facilities, and DOE-STD-1029-92, DOE Standard Writer's Guide for Technical Procedure. PROC-DI-001-01 was developed locally at the Hanford Site for technical procedure writers. PROC-DI-001-01 includes the technical procedure writing requirements of DOE-STD-1029-92. The Human Factors Area Council created DOE-STD-1029-92 to ensure that writers of technical procedures will follow basic human factors principles in their content, layout, and format of written technical procedures. DOE-STD-1029-92 complies with accepted human factors principles. Inclusion of DOE-STD-1029-92 demonstrates that human factors consideration are included in the technical writers' work. DOE-STD-1029-92 is used in its entirety to provide guidance to technical procedure writers."

Procedures play a key role in ensuring safe, deliberate, and controlled operations. The intent of DOE-STD-1029-92 is to provide a knowledgeable and reasonable approach to all aspects of procedure management that will ensure the availability and use of sound procedures at DOE facilities. DOE-STD-1029-92 provides a method for writers to ensure key questions are addressed and that procedures contribute to maintaining safe operations. For example, key human factors questions procedure writers are trained to answer, especially during a task analysis for the procedure, include:

- Who is the user and what is the user's level of experience and training?

- How does this document relate to other procedures for the equipment and facility?

- What materials, equipment, and facilities are to be used?

- What tasks are to be accomplished?

- Why, when, where, and how are the tasks to be accomplished?

Procedure writers learn that the operators are an important source of information when developing procedures. Personnel from the operational organization are involved in the process from the initial decision to write a procedure through the review, verification, and validation of the procedure. 


\section{SNF-4831 REV 0}

CSB facility operators can provide valuable insight into the job being performed, information about past operating experience, and data for developing the procedure basis of the procedure. Their involvement in the process can include participating in walkthroughs and identifying behavioral obstacles, cautions, and valuable nonstandard source documentation beyond safety analysis reports, probabilistic risk assessments, technical safety requirements, vendor manuals, and old procedures.

The procedure is constructed and written to communicate to the procedure user all information needed to successfully operate the system within its design environment. Human factors considerations would include such things as using simple and concise language; using action statements; maintaining consistency in language and format among instrument labeling, procedures and training; avoiding ambiguity, limiting us of abbreviations and acronyms, adhering to grammatical conventions and syntax of standard American English, etc.

The procedure is verified and validated during the test and evaluation of the system. 


\section{SNF-4831 REV 0}

This page intentionally left blank. 


\subsection{HUMAN ENGINEERING DEFICIENCY TRACKING}

Human Engineering Deficiency (HED) Tracking should be applied to each CSB system. The purpose for this is to track concerns to resolution or disposition that are discovered during periodic HFE/Erg Reviews. One can create a log or table with appropriate numbering and nomenclature for each HED, preferably identified by system and subsystem and grouped accordingly. The table should include the resolution or disposition of each HED, by describing the solution to the concern. The HED Tracking should be kept in the engineering office and reviewed periodically at engineering meetings. Any time a new HED is discovered, it should immediately be recorded in the HED Tracking system. (NOTE: The draft of SNF-4399, Human Engineering Program Plan addresses HED and provides a recommended tracking system). It would be encouraging to have the vendors develop HEDs tracking for project engineering review concerning their specific systems, as applicable.

In addition, these items should have follow up with periodic HFE/Erg design reviews. The "proof of the project" will be the test and evaluation phase of the project, where all HED's should have been resolved before going into the Operational Test and Evaluation or preoperational test and evaluation phase of the SNF Project. The FSAR should be updated from the periodic HFE/Erg evaluations of the CSB subsystems.

\subsection{TEST AND VALIDATION}

Testing and validation will include the operator(s) walking through each system procedure (i.e., each step will be checked against the actual equipment and controls to ensure the step is technically accurate) before issue of the procedure in order to verify that they will perform their function, including human factors. This will also accomplish the verification that the system meets requirements.

SNF-4399 will address the human factors and ergonomics processes in testing and validation in detail. The HEPP will meet the requirements of DOE Order 6430.1A, Section 1300, as applicable.

\subsection{DISCUSSION OF HUMAN FACTORS ENGINEERING/ERGONOMIC DEFICIENCIES/DEVIATIONS FROM CANISTER STORAGE BUILDING HUMAN FACTORS ENGINEERING REPORT (SNF-3907)}

This section discusses HFE/Erg deficiencies or deviations from full compliances asserted in the initial HFE analysis (SNF-3907). These HFE/Erg issues have been reviewed by the appropriate design authorities.

The issue is whether the CSB facility will comply with the applicable criteria of the following HFE DOE Order(s) and Standards (as called out in the CSB-related standards/requirements identification documents): 


\section{SNF-4831 REV 0}

- $\quad$ DOE Order 5480.23, Attachment 1, Section 14 (Human Factors)

- DOE Order 6430.1A, General Design Criteria (Section 1300-12, Human Factors)

- NUREG-0700, Rev 1, 1995 (as approved 1996), Human System Interface Design Review Guideline.

- NUREG-0800, Standard Review Plan for the Review of Safety Analysis Reports for Nuclear Power Plants, Section 18.1, "Human Factors Engineering, Control Room."

- $\quad$ DOE-STD-1062-94, Human Factors Engineering Design Criteria, Draft, Volume 1.

These are the primary compliance documents and are supplemented with other standards, which are used for guidance purposes. Judging from the current work already accomplished on the CSB, it is apparent that inclusion of HFE/Erg design criteria has been discussed by engineering and included in the design, as appropriate. Though the rail frogs, the mobile tent, and the weld station are undergoing design or design modifications, engineering is aware of the need for including HFE/Erg design criteria in the final design, as applicable. The test and validation (indicated above in section 7.1) phase of the project will provide the opportunity to re-check these systems and their applicable human-machine interfaces (HMI).

Engineering is aware of the issues identified in SNF-3907, Table 5-3 (Summary of HEDs from Previous Reviews). There were 25 outstanding issues at the time of the report. ALL but one issue appear resolved, at this time. The outstanding issue concerns, item \#14, indicating reach distance to work over the MCO should be redesigned to provide for a maximum reach distance of 20 in.. Redesign of the pit mobile tent or elimination of the tent altogether will continue to be monitored for this issue of manual reach distance. This issue is to be put into the CSB HEDs tracking file.

It is noted that $12 \%$ of the criteria considered as non-compliant was resolved by engineering (SNF-3907, page 26). The administrative features indicated involved training, written procedures, staffing and direct oversight or any combination capable of compensating for $\mathrm{HFE}$ engineering deficiency. Examples given included "improper positioning of displays and controls relative to one another that preclude individual workers from operating the equipment can often be overcome by adding a second participating worker. Or, another example provided, marginal labeling can often be overcome through additional training or expanded written procedures for operating equipment associated with the marginal labeling.

It should be noted that for the MHM, a redesign effort corrected HFE/Erg deficiencies, by repositioning and grouping controls and displays. Additional demarcation on the panel should be used to separate out the groupings. During operator evaluation of a MHM control panel simulator, additional ideas were provided to engineering through the training department, which conducted the simulator evaluations to gather information for the training and procedure development. These ideas included demarcation of the controls, possible elimination of some of the indicator lights, redesign of the "mushroom" emergency stop and relocation of the emergency stop button because of possible inadvertent operation. The HFE/Erg solution would be to 


\section{SNF-4831 REV 0}

relocate the emergency stop button and provide a guard for the button to prevent inadvertent actuation.

It should be noted that since the completion of SNF-3907, the MCO Handling Machine System Operations \& Maintenance Manual (Volume 15) has been released. This manual describes in great detail the necessary operations and maintenance procedures required for the MHM. The color charts, and figures will greatly assist the operators and maintainers during their training for operating the MHM. provided:

In summary of the current HFE/Erg status of the CSB design, the following information is

The sampling/weld station will not be completed until late August, however, review of the pit design, glove box work area, tools, indicate that HFE/Erg are included in the design. For example, as much automation as possible is being designed into the Sampling/weld station to minimize both human exposure to possible contamination and to eliminate or reduce the biomechanical effort expended in this work area.

The overpack tube plug is designed, but not available yet. Engineering concern is in minimizing human exposure to possible contamination and reducing biomechanical forces involved in operations with the tube plug.

The mobile tent may possibly be eliminated, thus removing a biomechanical concern of manually pushing the heavy tent within the service station area.

The inclusion of two "crash gates" at garage door entries will include rolling garage doors (up and down) using a motorized system. The only human interaction is by way of a pushbutton(s).

The tube vent and purge cart has included.HFE/Erg requirements in the design as evidenced by examination of the design criteria. This subsystem will be tested and validated, including HFE/Erg specified criteria.

The CSB staffing plan was updated in 1998 and reviewed (in this report).

The MCO grapple will not be a problem for HMI. This is the grapple that attaches to the MCO mobile station hatch assembly. Associated with grappling are is the hoist assembly. The hoist assembly will not incur any problems for HMI, either. Hoisting will either be accomplished using two operators (one acting as an observer for the crane operator), or the crane operator will use a radio control operation, while working outside the crane operations booth, and perform the necessary operations. It would still be advisable to include a safety observer during crane hoisting lifting and moving operations. This should be a focus area during the test and validation phase.

MCO flex connectors and piping are being designed to minimize the effort of HMI, possibly using appropriately designed snap on connectors, where applicable. 


\section{SNF-4831 REV 0}

Tool design is includes applicable HFE/Erg considerations, for example, instead of using manual torque wrenches, the inclusion of the automatic torquing tools is being re-considered.

The DCS, HVAC, GEMS, and communication systems appear adequately designed for both operations and maintenance requirements. The HVAC system is impressive by its design for accessibility of all parts that are routinely inspected or calibrated. Changeout of HEPA filters include ease of accessibility, if changeout is required during the life of the CSB receiving operations.

The following information should be discussed by engineering to investigate possible changes before the test and validation phase:

MHM alarm and indicator panel should include a grid system to facilitate location of indicator lights (especially if being referenced from an operations manual). For example, each column would contain a numeric indicator, and each row would contain an alpha indication I(i.e., an indicator would be labeled as positioned at Row "C", Column "4" -- "C4").

MHM control panel should have demarcation boundaries for each grouping of controls.

MHM could include a provision for providing alarm information on the monitor. This may include cause of alarm, and corrective action displays. This may not be feasible at this time though because of cost and software re-engineering. But the idea is offered for consideration.

MHM should provide a place for the operator to sit down. Currently all operations are conducted from the standing position. (It is not known if an operator will be standing for $\mathbf{8}$ hours at the MFM control panel, during operations).

It appears the DCS provides non-specific indications or alarm locations. For example, the RAD alarm does not specify the exact problem or tell the operation specifically where the problem is (location in the building). This needs to be addressed by software engineering, to indicate exactly what the problem is and exactly where the alarm location is in the building. This will avoid momentary confusion if an alarm goes off.

It has been discovered that the cask receiving crane and the MHM hoist control joysticks move opposite from each other. This condition needs to be corrected to expectations of the HNF site control operators. Both joysticks should provide the same operations using the same movements (e.g., forward/backward joystick movement on both systems should result in the same operation). 


\section{SNF-4831 REV 0}

\subsection{LIMITATIONS OF THIS REPORT}

This report was generated to review the human factors engineering and ergonomics of the entire CSB system. This report should not be used as the sole basis for determining if CSB human factors meet FSAR requirements.

This report only serves to review the CSB systems and other HFE reports that have been generated. This report was limited in detail because of a number of factors, including: initial familiarization with the CSB system, understanding previous CSB HFE issues, time constraints in meeting the Project timeline to complete the FSAR, and in some cases, lack of information, data, or design conceptualization at this time. Though some designs may be incomplete, the opportunity exists to insert HFE requirements where engineering is designing or modifying equipment. Periodic HFE evaluations of ongoing design consideration should be accomplish.

HFE in test and evaluation to validate systems, should be given careful consideration with use of checklist guidelines, to ensure each step in the process can be completed in a safe and efficient manner. 


\section{SNF-483 1 REV 0}

This page intentionally left blank. 


\section{SNF-4831 REV 0}

\subsection{REFERENCES}

10 CFR 72, 1995, "Licensing Requirements for the Independent Storage of Spent Nuclear Fuel and High-Level Radioactive Waste," Code of Federal Regulations, as amended.

10 CFR 835, "Occupational Radiation Protection," Code of Federal Regulations, as amended.

ANSI/ANS-57.2-1992, 1992, Design Requirements for Light Water Reactor Spent Fuel Storage Facilities at Nuclear Power Plants, American Nuclear Society, La Grange Park, Illinois.

ASHRAE 90-75R, 1975, Energy Conservation in New Building Design, American Society of Heating, Refrigeration and Air Conditioning Engineers, Atlanta, Georgia.

ASME B31.1, 1995, Power Piping Code, American Society of Mechanical Engineers, New York, New York.

ASME B31.3, 1996 Process Piping Code, American Society of Mechanical Engineers, New York, New York.

DOE Order 5480.19, Change 1, 1992, Conduct of Operations Requirements for Department of Energy Facilities, U.S. Department of Energy, Washington, D.C.

DOE Order 5480.23, Change 1, 1994, Nuclear Safety Analysis Reports, U.S. Department of Energy, Washington, D.C.

DOE Order 6430.1A, April 6, 1989, General Design Criteria, Section 1300-12, "Human Factors Engineering," pages 13-34 to 13-43, U.S. Department of Energy, Washington, D.C.

DOE-STD-1029-92, DOE Writer's Guide for Technical Procedures, U.S. Department of Energy, Washington, D.C.

DOE-STD-1062-94, 1994 Human Factors Engineering Design Criteria, Draft, Volume 1. U.S. Department of Energy, Washington, D.C. 1994. [NOTE: this standard now is defunct, but the information contained in it is still useful as a guide in supplementing other HFE/Erg standards]

DOE STD-3009-94, 1994, Preparation Guide for U.S. Department of Energy Nonreactor Nuclear Facility Safety Analysis Reports, Chapter 13, "Human Factors." U.S. Department of Energy, Washington, D.C.

DOE 1993b, DOE Filter Plenum Fire Protection Standard, Rev 4, U.S. Department of Energy, Washington, D.C.

H-2-123400, Operational Sequence Block Flow Diagram Overview, sheets 1-7 


\section{SNF-4831 REV 0}

HNF-3553, 1999, Spent Nuclear Fuel Project, Final Safety Analysis Report (FSAR), Fluor Daniel Hanford, Incorporated, Richland, Washington.

HNF-SD-SNF-HIE-001, 1999, Canister Storage Building Hazard Analysis, Rev. 1, Fluor Daniel Hanford, Incorporated, Richland, Washington.

HNF-SD-SNF-PD-011, Rev 2, December, 1998, Spent Nuclear Fuel Project Operational Staffing Plan, Fluor Daniel Hanford, Incorporated, Richland, Washington.

IES, 1987, Lighting Handbook, Illuminating Engineering Society of North America, New York, New York.

INEL-95/0117, 1995, Human Factors Engineering Checklists for Application in the SAR Process, Idaho National Engineering Laboratory, Idaho Falls, Idaho.

Mahaffey, M. K., 1997, Response to Issues Associated With Fabrication Release for the Spent Nuclear Fuel Project Multi-Canister Overpack Handling Machine, (letter FDH 9755210R1 to E. D. Sellers, August 15), DE\&S Hanford, Inc. for Fluor Daniel Hanford, Inc., Richland, Washington.

Mahaffey, M. K., 1998, Contract Number DE-AC06-96RL13200: Update of 22 Issues From the U. S. Department of Energy, Richland Operations Office Review of Multi-Canister Overpack Handling Machine, Supporting Key Driver Resolution Committee Process for Multi-Canister Overpack Handling Machine Installation, (letter FDH 9855462 to E. D. Sellers, July 2), DE\&S Hanford, Inc. for Fluor Daniel Hanford, Inc., Richland, Washington.

MIL-STD-1472D, 1989, Human Engineering Design Criteria for Military Systems, Equipment, and Facilities, U.S. Department of Defense, Washington, D.C.

NFPA-780, 1995, Lighting Protection Systems, National Fire Protection Association, Quincy, Massachusetts.

NUREG-0700, Rev 1, 1995 (as approved 1996), Human System Interface Design Review Guideline, U.S. Nuclear Regulatory Commission, Washington, D.C.

NUREG-0800, 1996, Standard Review Plan for the Review of Safety Analysis Reports for Nuclear Power Plants, Section 18.1, "Human Factors Engineering, Control Room," U.S. Nuclear Regulatory Commission, Washington, D.C.

NUREG/CR-6407, Classification of Transportation Packaging and Dry Spent Fuel Storage Systems, U.S. Nuclear Regulatory Commission, Washington, D.C.

PROC-DI-001-01, SNF Project Technical Procedures Writer's Guide, Fluor Daniel Hanford, Incorporated, Richland, Washington. 


\section{SNF-4831 REV 0}

SNF-3907, 1999, Human Factors Engineering (HFE) Analysis: Results and Findings, Fluor Daniel Hanford, Incorporated, Richland, Washington.

SNF-4399, 1999, Human Engineering Program Plan, Fluor Daniel Hanford, Incorporated, Richland, Washington. 
SNF-4831 REV 0

This page intentionally left blank. 
SNF-4831 REV 0

APPENDIX A

\section{OPERATIONAL SEQUENCE BLOCK FLOW DIAGRAM OVERVIEW}

(H-2-123400, SHEETS 1-7) 
This page intentionally left blank. 


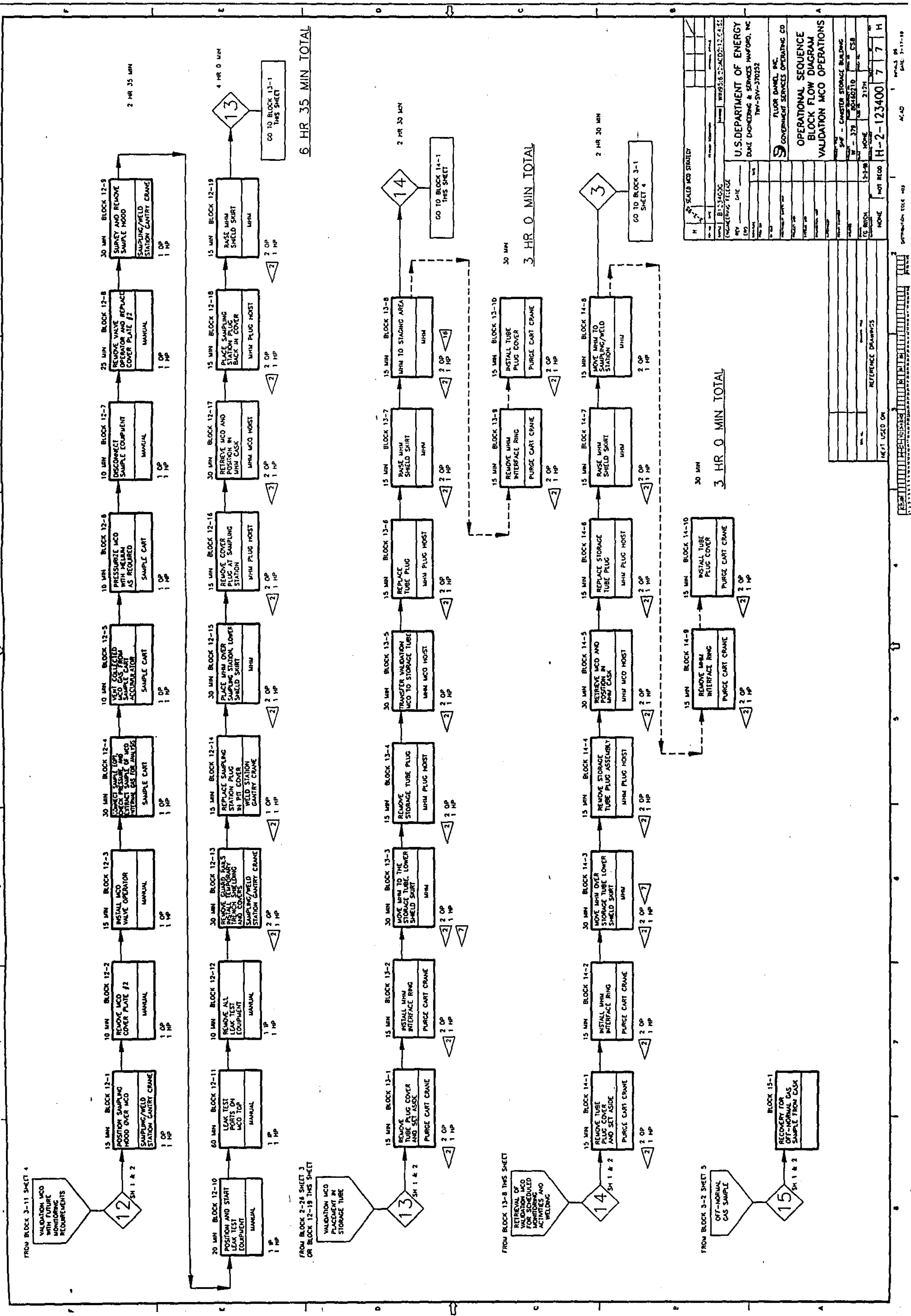




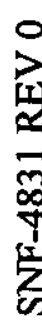

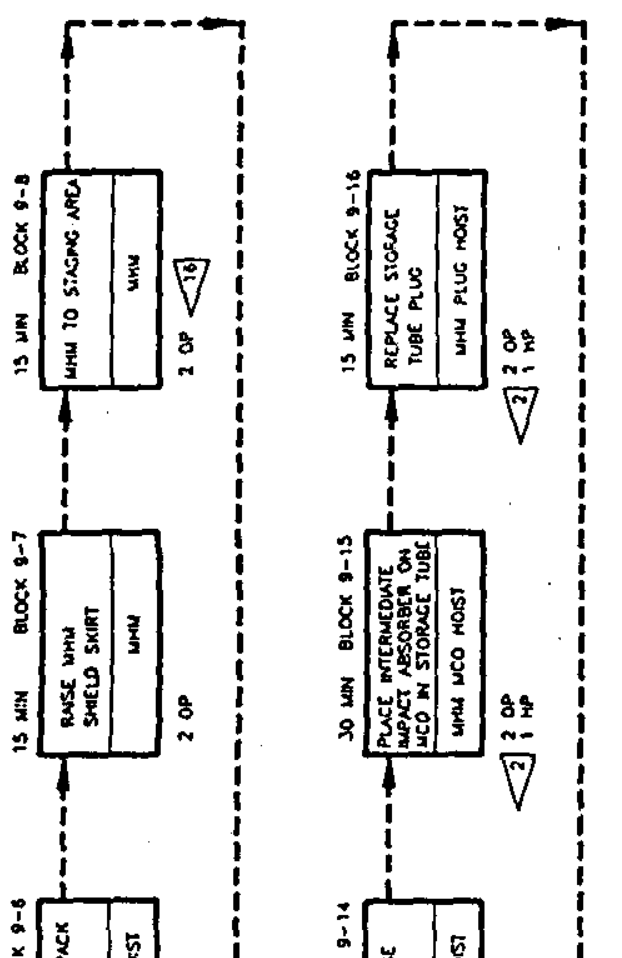

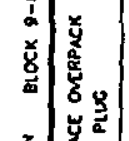

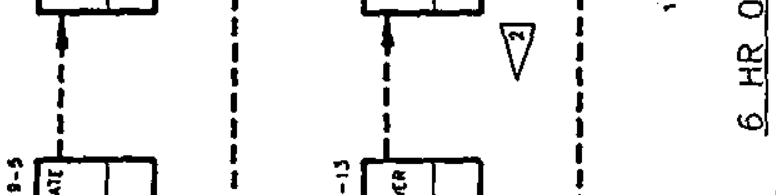

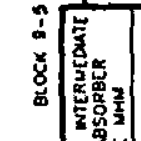

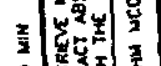

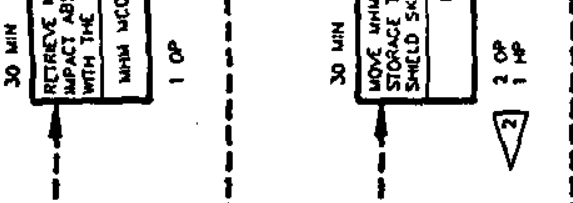

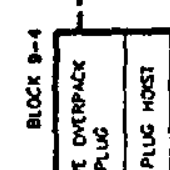

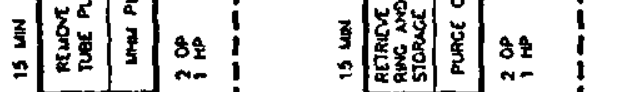
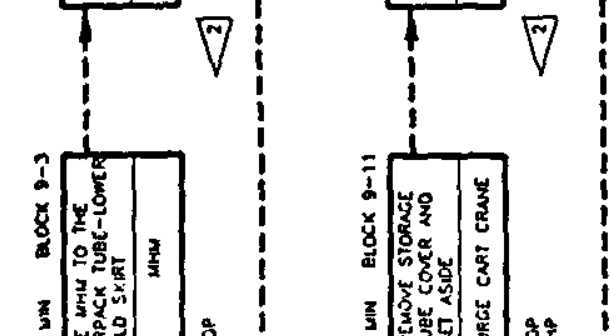

I

等

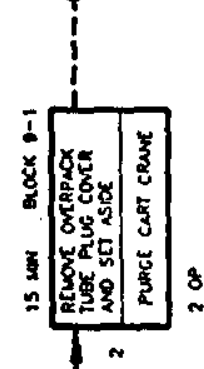

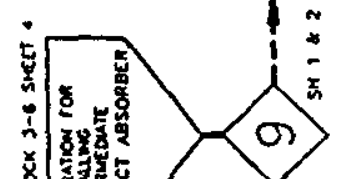

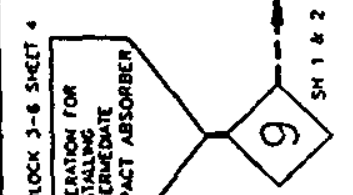

造

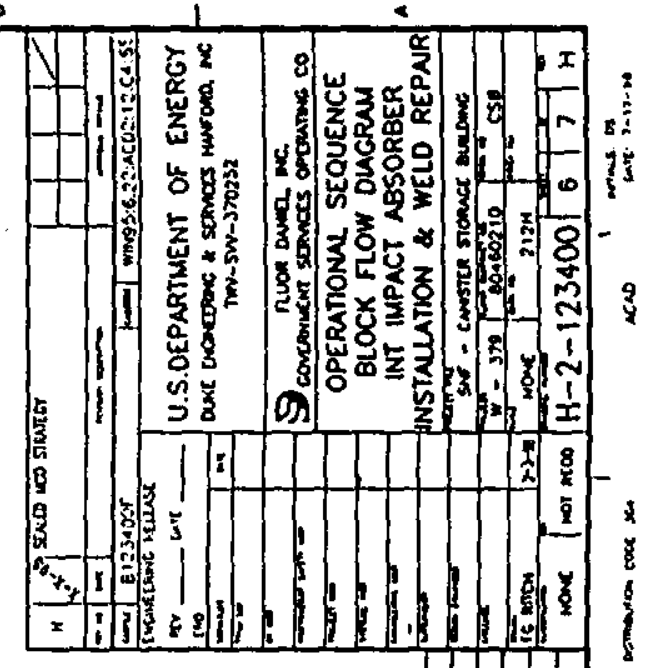

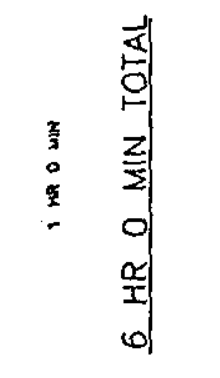

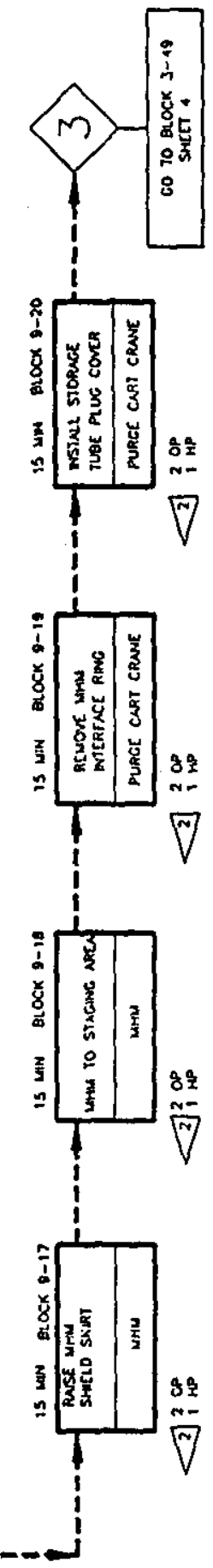

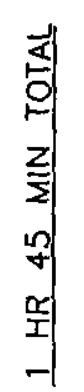

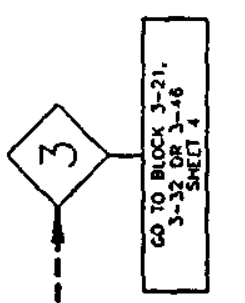

施总

烈

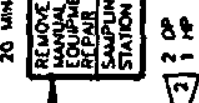

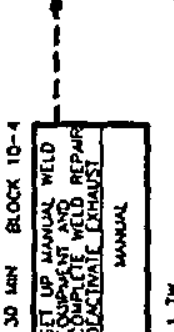

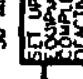
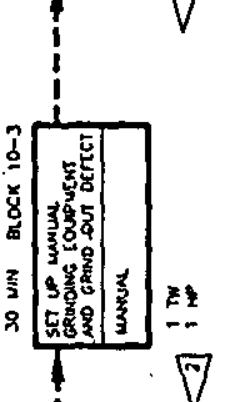

急

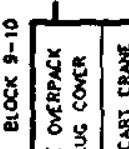

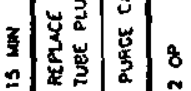

$T$

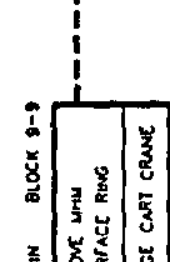

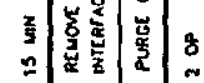

(1)

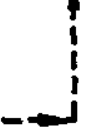




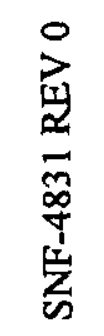

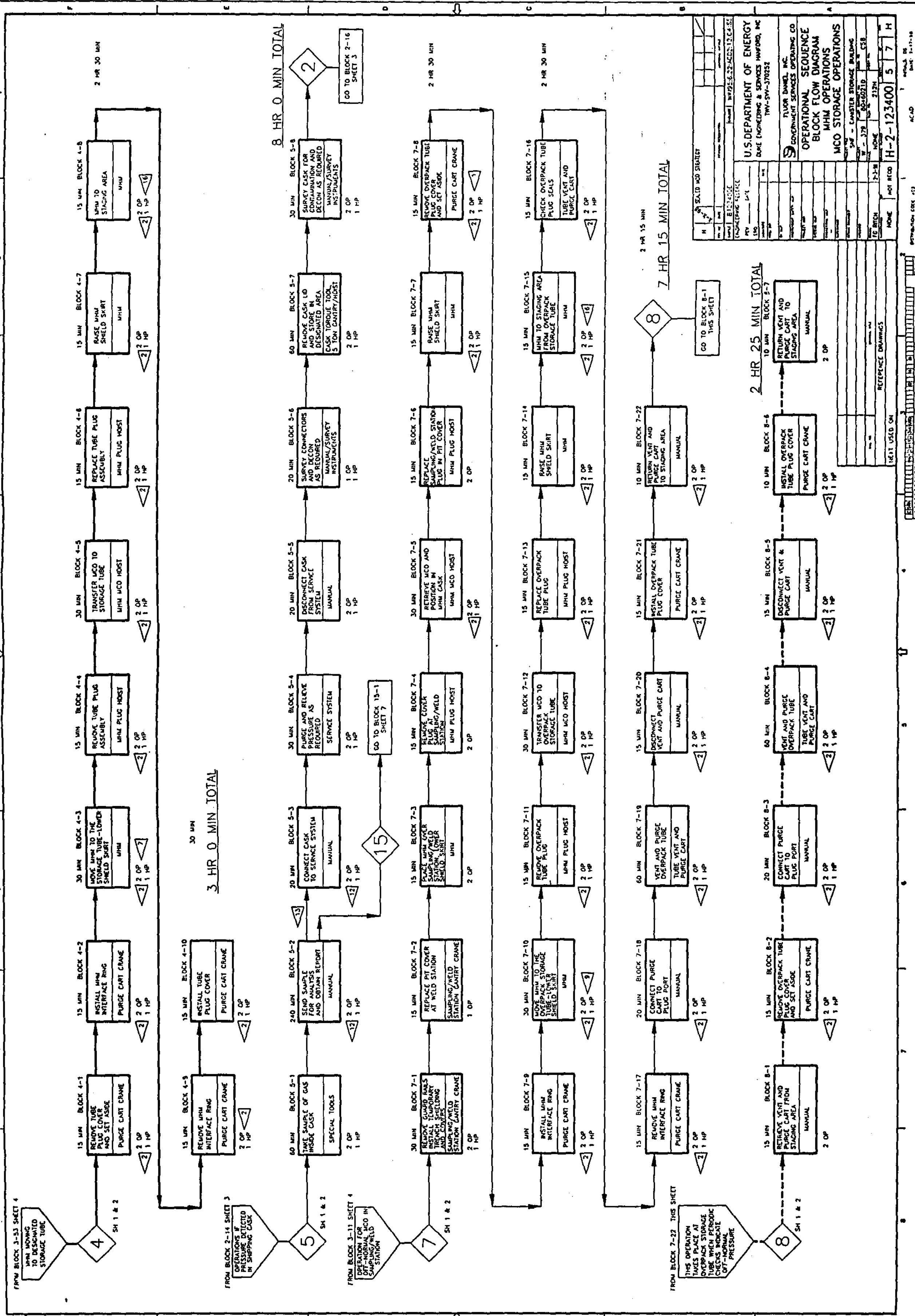


盆

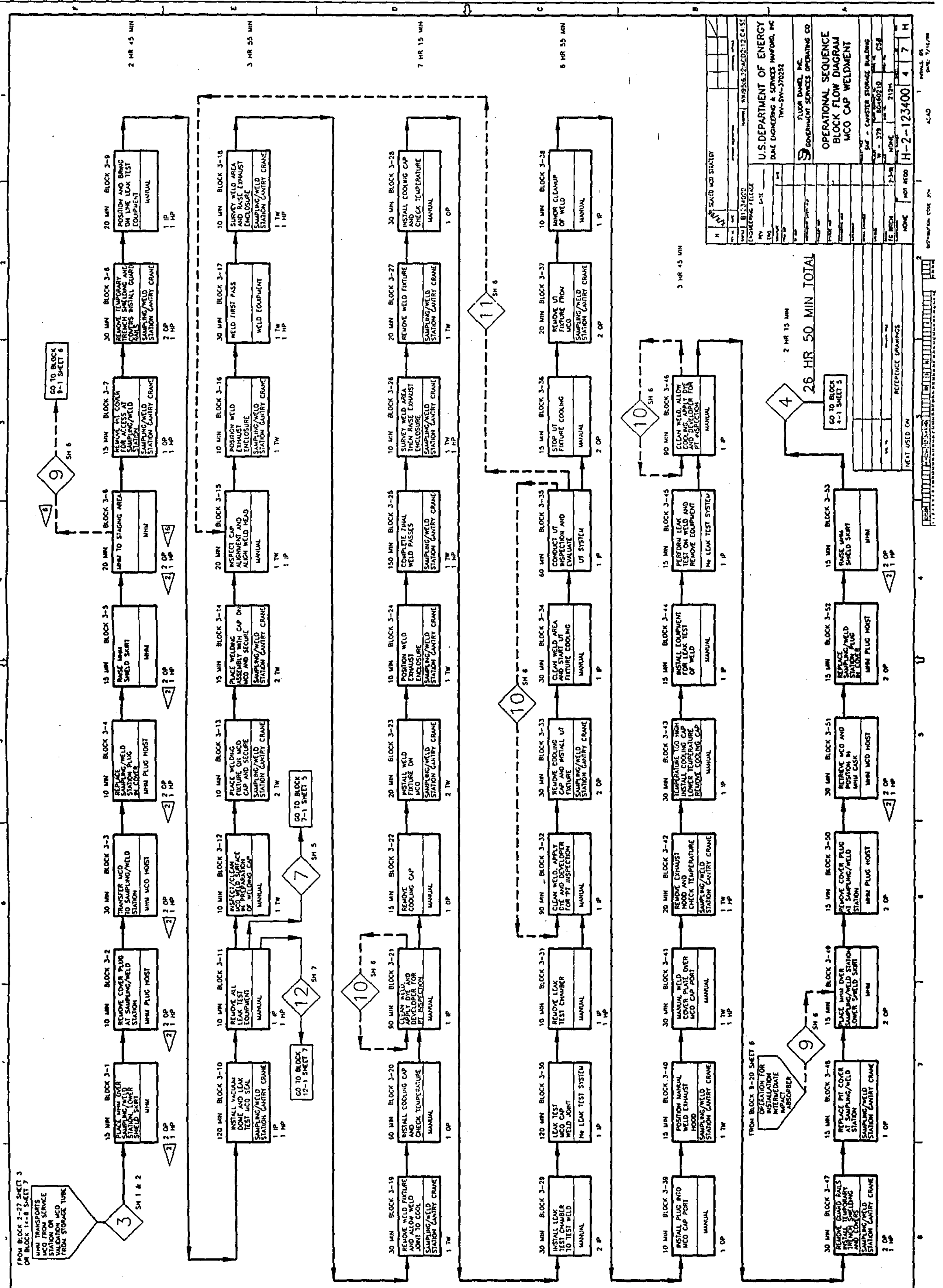


竞

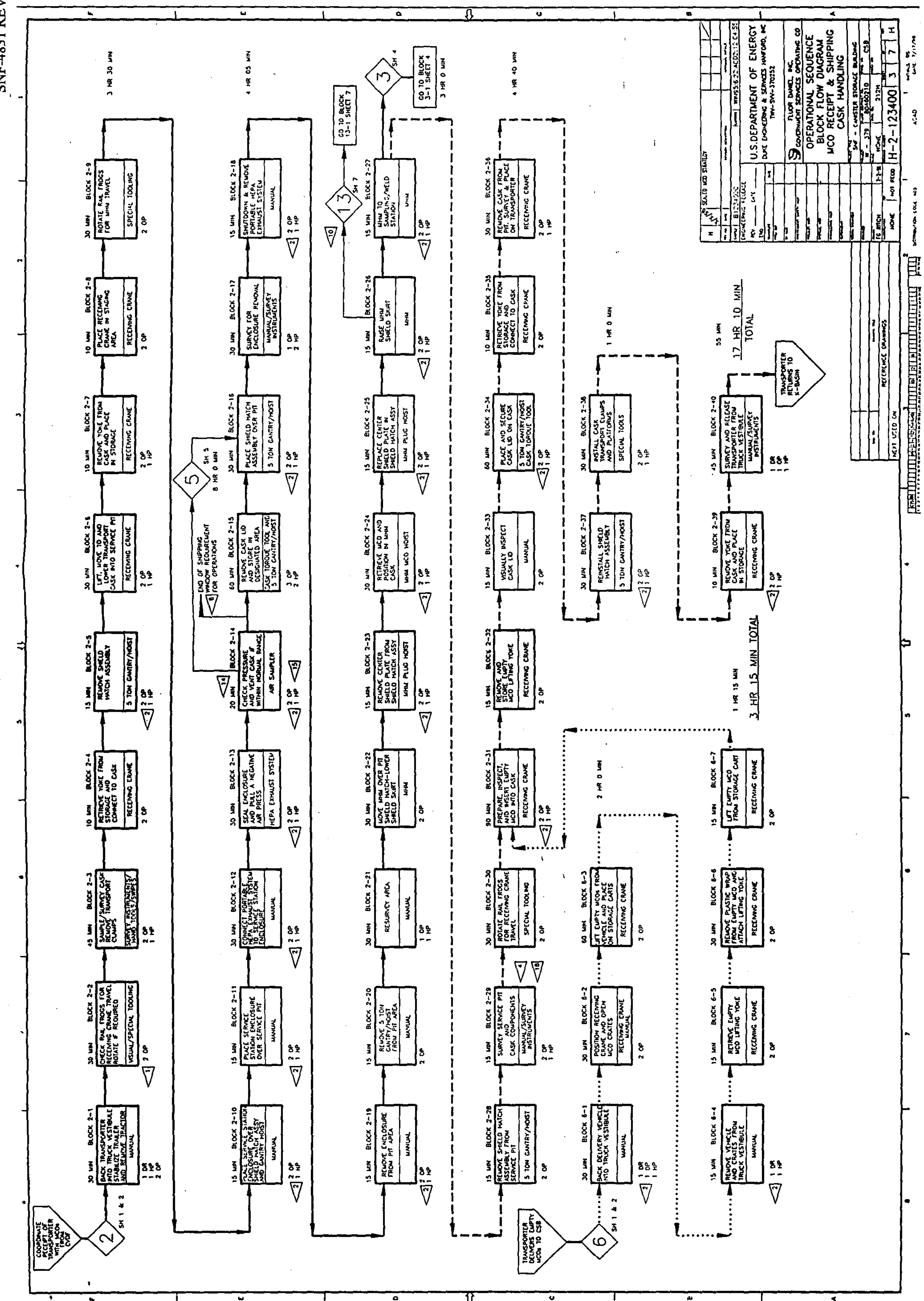

S

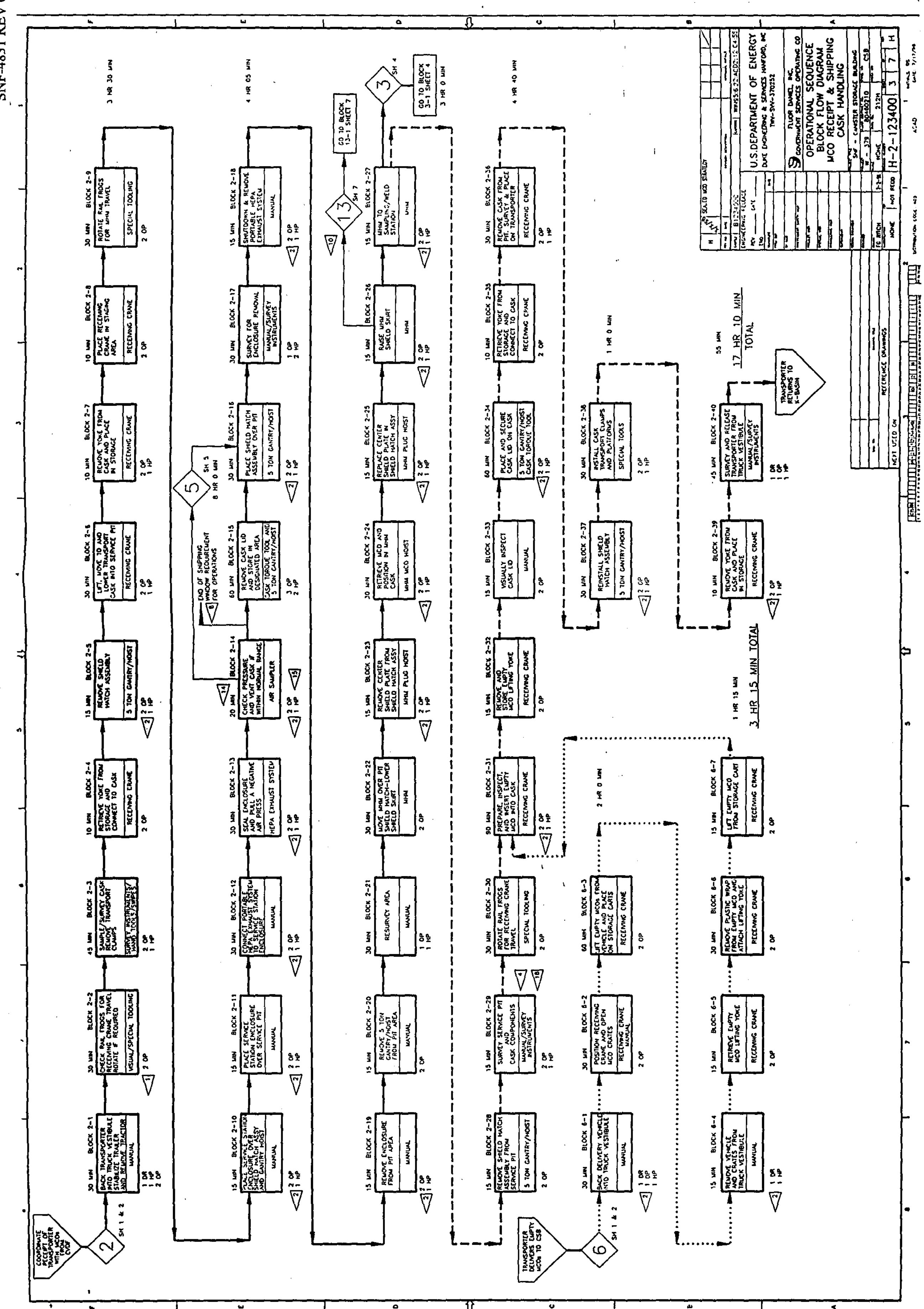


总

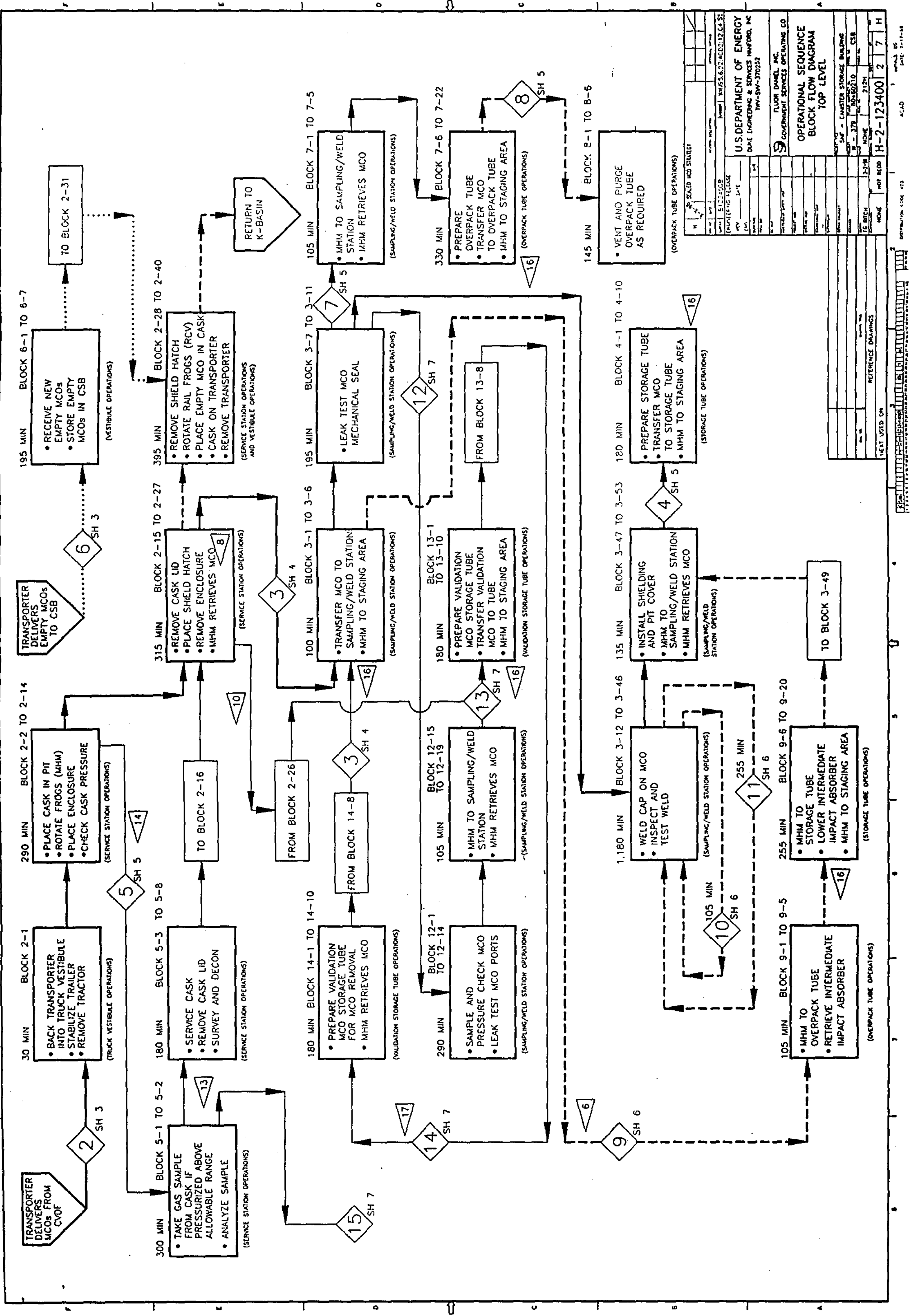




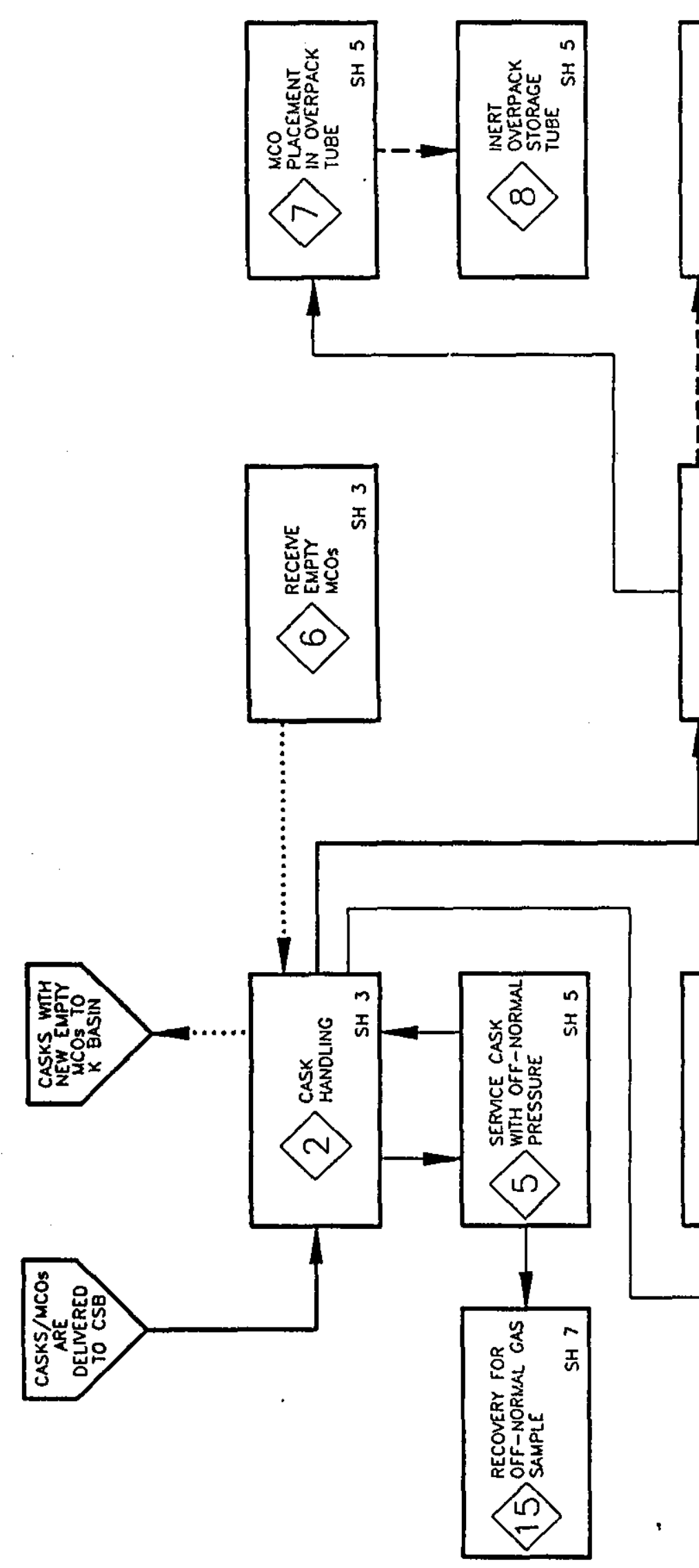

$\Rightarrow$

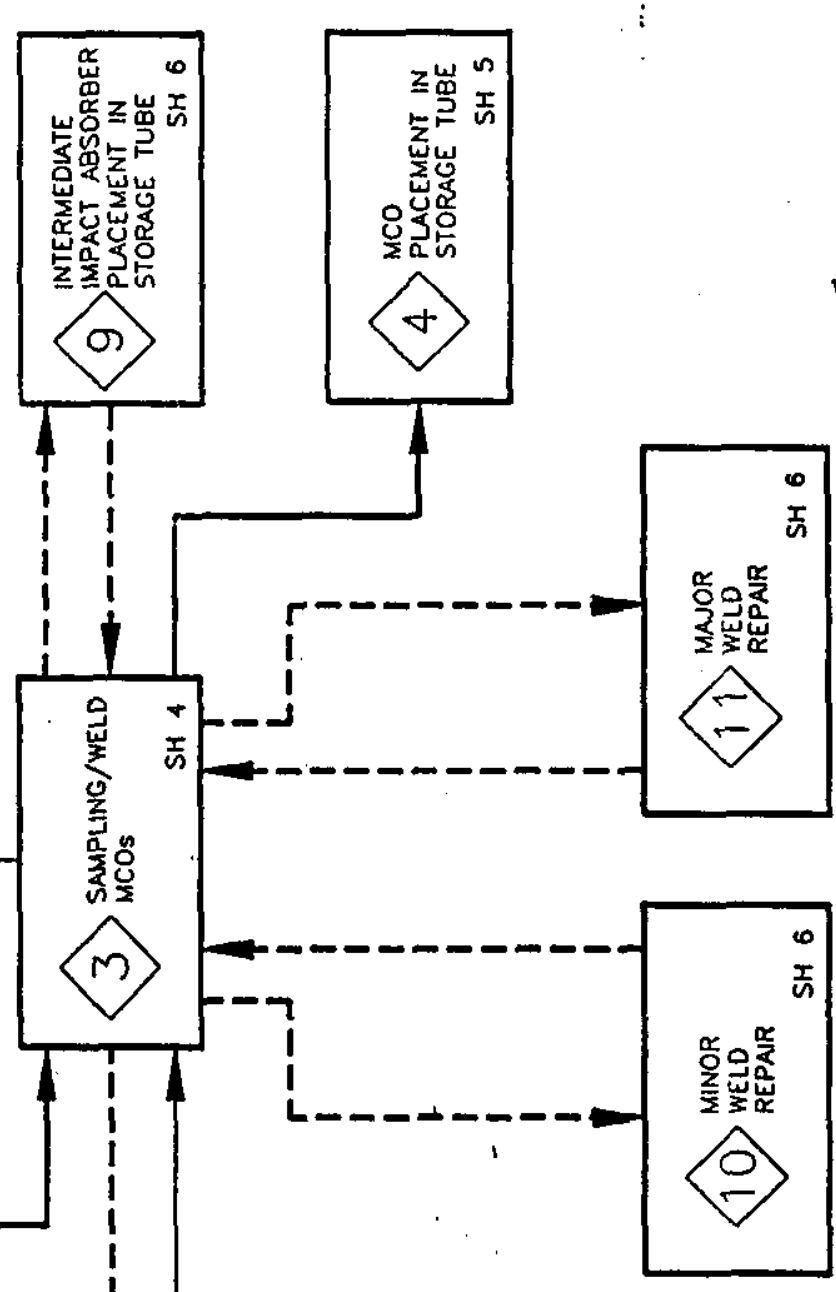

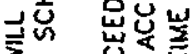

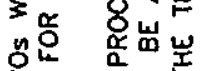

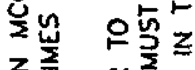

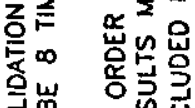

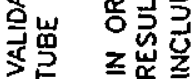

月圈

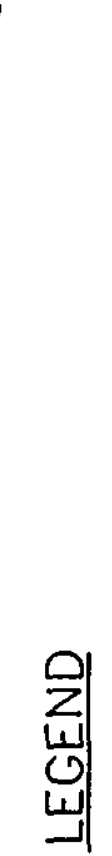

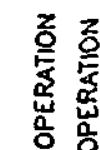

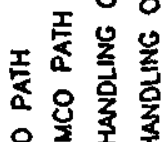

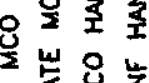

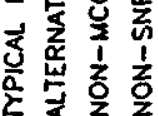

$1 \mid 10$

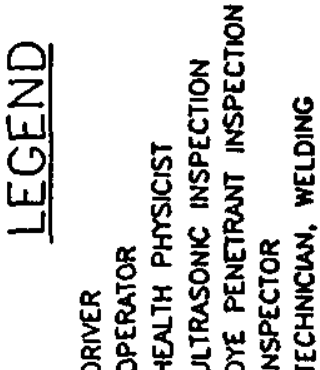

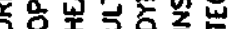

응영오 5 모으
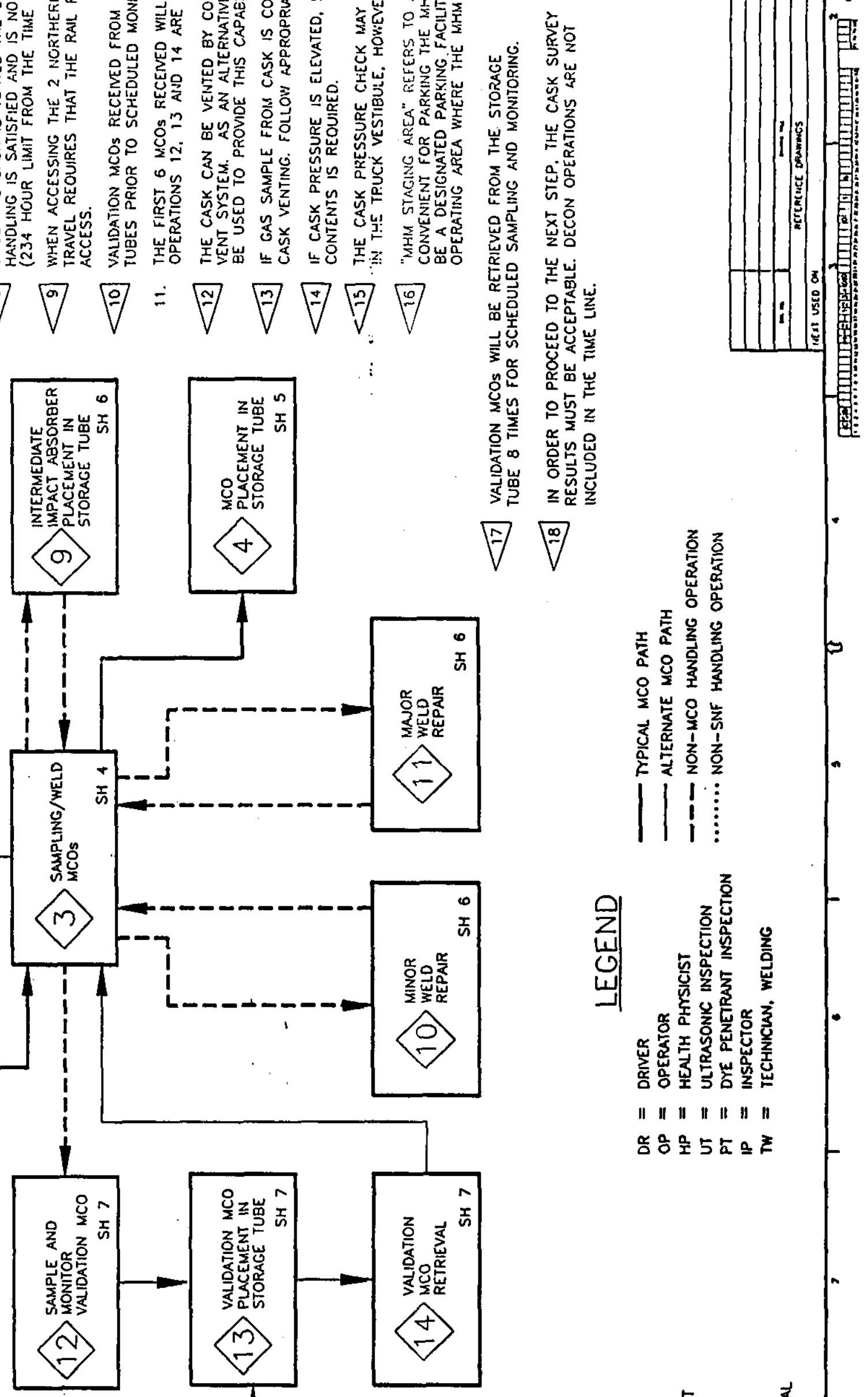


\section{DISTRIBUTION SHEET}

\begin{tabular}{|c|c|c|c|c|c|}
\hline \multirow{2}{*}{$\begin{array}{l}\text { To } \\
\text { Distribution }\end{array}$} & \multirow{2}{*}{\multicolumn{3}{|c|}{$\begin{array}{l}\text { From } \\
\text { Nuclear Safety }\end{array}$}} & \multicolumn{2}{|l|}{ Page 1 of 1} \\
\hline & & & & \multicolumn{2}{|c|}{ Date $9-16-99$} \\
\hline \multicolumn{4}{|l|}{ Project Title/Work Order } & \multicolumn{2}{|c|}{ EDT No. 626889} \\
\hline \multicolumn{4}{|l|}{ SNF-4831, Rev. 0} & \multirow{2}{*}{\multicolumn{2}{|c|}{ ECN No. N/A }} \\
\hline \multicolumn{4}{|c|}{$\begin{array}{l}\text { Human Factors Engineering and Ergonomics Analysis for the Canister Storage } \\
\text { Building: Results and Findings }\end{array}$} & & \\
\hline Name & MSIN & $\begin{array}{c}\text { Text } \\
\text { With All } \\
\text { Attach. }\end{array}$ & Text Only & $\begin{array}{c}\text { Attach// } \\
\text { Appendix } \\
\text { Only }\end{array}$ & $\begin{array}{c}\text { EDT/ECN } \\
\text { Only }\end{array}$ \\
\hline G. D. Bazinet & S8-06 & $\mathbf{x}$ & & & \\
\hline A. S. Daughtridge & R3-86 & $\mathbf{x}$ & & & \\
\hline R. P. DiPiazza & R3-26 & $\mathbf{X}$ & & & \\
\hline L. J. Garvin & R3-26 & $\mathbf{x}$ & & & \\
\hline S. B. Harrington & R3-26 & $\mathbf{x}$ & & & \\
\hline O. M. Serrano & R3-86 & $\mathrm{X}$ & & & \\
\hline C. E. Swenson & S8-07 & $\mathrm{X}$ & & & \\
\hline SNF Project Files & R3-11 & $\mathbf{X}$ & & & \\
\hline
\end{tabular}

